\title{
Brush up your Shakespeare; Costuming West Virginia University's Production of "Kiss Me Kate"
}

\author{
Cecelia A. Hill
}

Follow this and additional works at: https://researchrepository.wvu.edu/etd

\section{Recommended Citation}

Hill, Cecelia A., "Brush up your Shakespeare; Costuming West Virginia University's Production of "Kiss Me Kate"'" (2016). Graduate Theses, Dissertations, and Problem Reports. 5803.

https://researchrepository.wvu.edu/etd/5803

This Thesis is protected by copyright and/or related rights. It has been brought to you by the The Research Repository @ WVU with permission from the rights-holder(s). You are free to use this Thesis in any way that is permitted by the copyright and related rights legislation that applies to your use. For other uses you must obtain permission from the rights-holder(s) directly, unless additional rights are indicated by a Creative Commons license in the record and/ or on the work itself. This Thesis has been accepted for inclusion in WVU Graduate Theses, Dissertations, and Problem Reports collection by an authorized administrator of The Research Repository @ WVU. For more information, please contact researchrepository@mail.wvu.edu. 


\title{
Brush up your Shakespeare; Costuming West Virginia University's Production of Kiss Me Kate
}

\author{
Cecelia A. Hill \\ Thesis submitted to the \\ College of Creative Arts at West Virginia University \\ in partial fulfillment of the requirements for the degree of \\ Master of Fine Arts \\ in \\ Design and Technical Theatre: Costume Design and Technology \\ Mary McClung, M.F.A. (Chair) \\ Bryce Britton, M.F.A. \\ Alan McEwen, M.F.A. \\ Steven Neuenschwander, M.F.A. \\ School of Theatre and Dance \\ Morgantown, West Virginia \\ 2016
}

Keywords: Costume Design, Theatre, Kiss Me Kate, Cole Porter

Copyright 2016 Cecelia A. Hill 


\section{Abstract \\ Brush up your Shakespeare; Costuming West Virginia University's Production of Kiss Me Kate \\ Cecelia Hill}

Kiss Me Kate provides an interesting challenge for costume designers in that it is set in 1940s Baltimore but stages a production of Taming of the Shrew within the musical. During the spring and fall of 2015 I was given the opportunity to design Kiss Me, Kate for my graduate costume design thesis project. I worked in collaboration with Professor Bryce Britton, director, Professor Robert Klingelhoefer, scenic designer, and Professor Alan McEwen, lighting designer. Professor Britton expressed his desire to create a "Technicolor dreamland" for our Elizabethan Renaissance show within a show, and Professor Klingelhoefer discussed the need for a duality between the two halves of the show. I aimed to portray a realistic 1940s era backstage while also designing a big and bold theatrical production of Taming of the Shrew. As costume designer my challenge was to manage a production that contained multiple eras requiring costume and character changes.

To accomplish this I researched thoroughly both Elizabethan Renaissance and 1940s Eras and engaged in a close reading of both Kiss Me Kate and Taming of the Shrew in order make design choices that reflected the characters in each show. These design choices were refined though a series of sketches with final design choices made in collaboration with Professor Britton. From this point on I was responsible for overseeing the transition of my designs from paper to reality by building a schedule for costume production, pulling and renting costumes, and organizing fittings for twenty six actors.

One of the most significant lessons I take away from this production is the importance of getting and staying organized. I accomplished this through detailed documentation of my vision and how it applied to each character and costume. I also learned the importance of staff management and asserting myself as a designer so that my design ideas are reflected in the finished costumes. 


\section{Acknowledgements}

I would like to thank my amazing parents for always supporting me and encouraging me to pursue my dreams.

Thank you to my Borg, Lauren Brennan and Cody Lorich, for being superstars and my second brains.

I would also like to thank my amazing production team; Professor Bryce Britton, Visiting Assistant Professor James Mitchell, Professor General MacArthur Hambrick, Professor Robert Klingelhoefer, Professor Alan McEwen, Ricky Moats, and Amber Steffey, for such a beautiful collaboration. It was truly inspiring to work with them. As well as the theatre faculty and staff at WVU for their expert guidance, especially Professor Mary McClung, Professor Sharon Goeres, Professor Steven Neuenschwander, and the Costume Shop.

Thank You. 
Contents

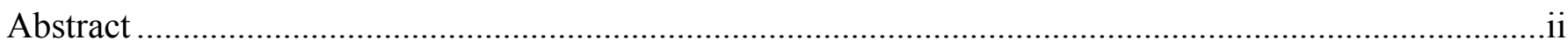

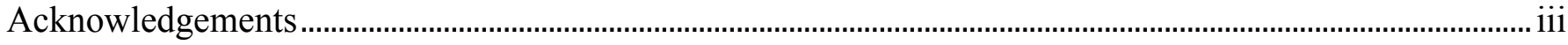

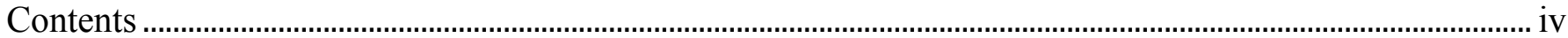

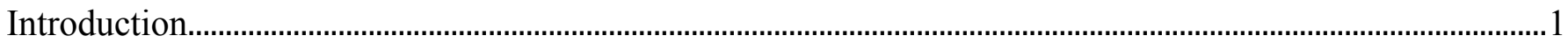

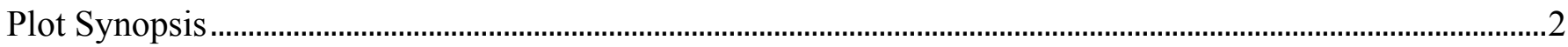

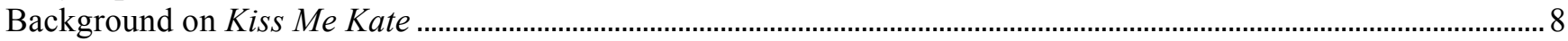

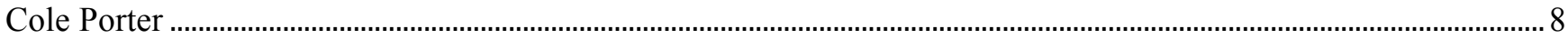

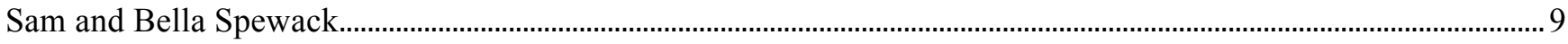

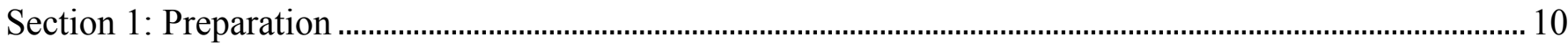

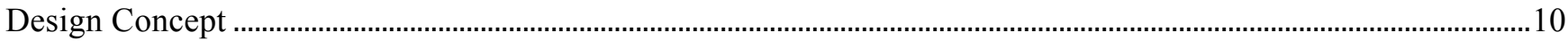

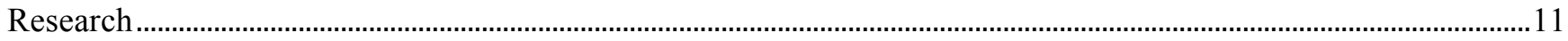

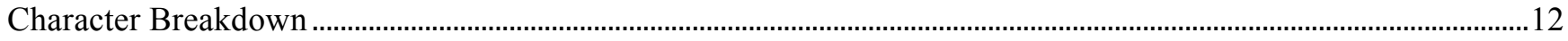

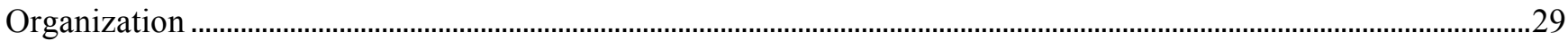

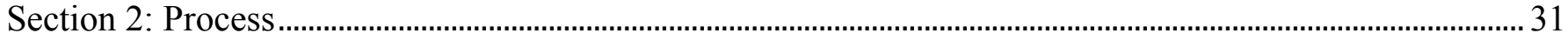

Section 3: Execution/Performance.................................................................................................................. 33

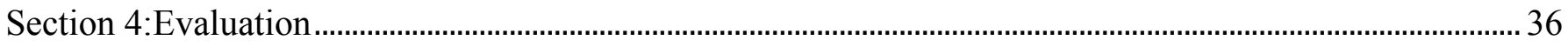

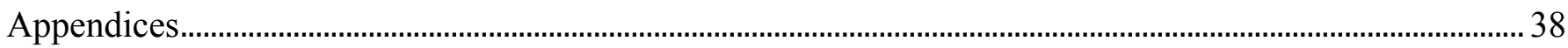

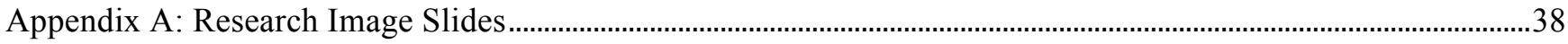

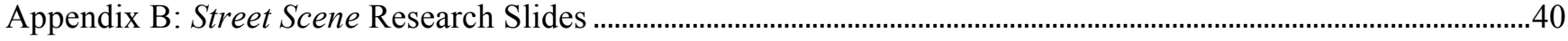

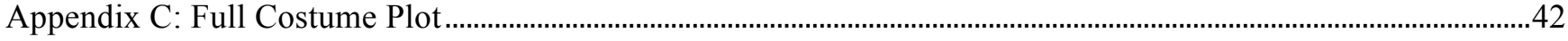

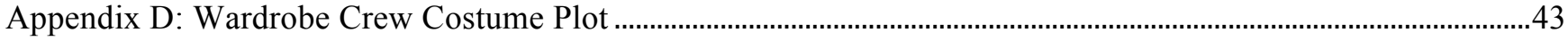

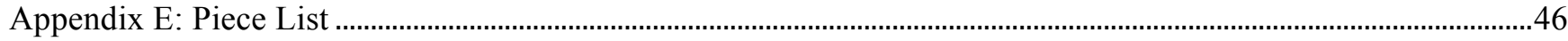

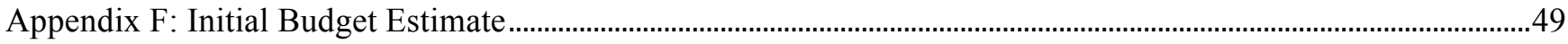

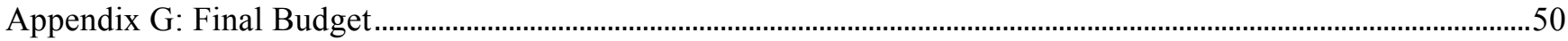

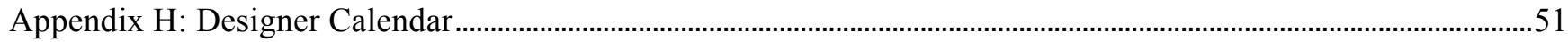

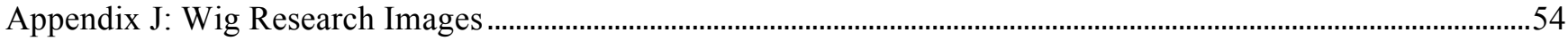

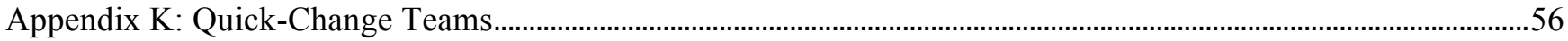

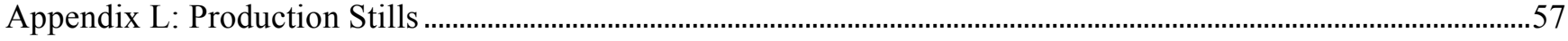

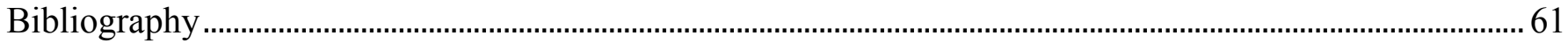

Index of Figures and Illustrations.................................................................................................................. 61 


\section{Introduction}

During the spring and fall of 2015 I was given the opportunity to design West Virginia University's production Kiss Me, Kate for my graduate costume design thesis. I had never designed a musical of this size and magnitude before, which provided me with quite the challenge managing multiple eras, looks, and character changes. The show was built in West Virginia University School of Theatre and Dance's costume shop over the course of seven weeks.

Professor Bryce Britton directed the production, with musical direction by Visiting Assistant Professor James Mitchell, and choreography by Professor General McArthur Hambrick. The design team consisted of a mixture of students and faculty. The scenic design was by Professor Robert Klingelhoefer, lighting design by Professor Alan McEwen, and sound design and engineering by undergraduate student Ricky Moats. Professor Steven Neuenschwander served as the Technical Director and Production Manager.

Our production of Kiss Me Kate was performed October Twenty-Third through Twenty-Fifth 2015 in the Lyell B. Clay Concert Theatre, a 1,440-seat theatre with a sixty-foot wide proscenium stage, located in West Virginia University’s Creative Arts Center. It featured a cast of twenty-eight undergraduate and graduate actors and actresses from the school's Musical Theatre, Acting, and Dance programs. The wardrobe crew for the show consisted of twelve undergraduate students including an undergraduate wardrobe supervisor who were all managed by one costuming graduate student. 


\section{Plot Synopsis}

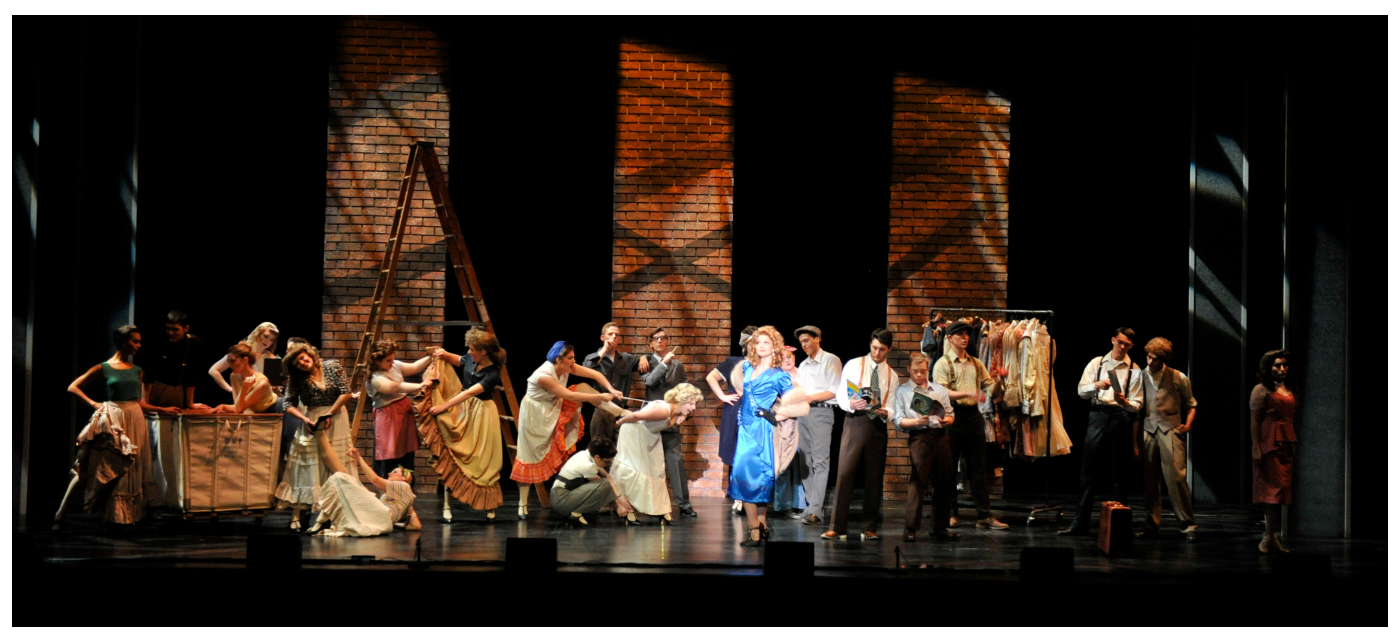

Figure 1: Lilli ‘s Entrance “Another Op'nin', Another Show.”

Kiss Me Kate opens in 1940s Baltimore as the cast and crew of a new musical version of The

Taming of the Shrew finish their final rehearsal prior to opening night. Fred Graham, lead actor, Producer, and Director, has cast his film star ex-wife Lilli Vanessi as Katherine in her return to the stage. Fred has also cast Lois Lane a sexy, young, nightclub singer in the role of Bianca, Katherine's sister. It becomes immediately evident that Fred has cast her to pursue her romantically as the rehearsal ends and he begins to give notes to the cast. However, as Fred starts to give notes to Lilli it is clear that they do not get along when they quarrel about how Lilli will bow at the end of the show. As Fred is giving notes we discover that one cast member is missing, Lois' boyfriend Bill Calhoun who is cast as Lucentio. Lois quickly covers for him saying that he is at the "chiro-podist" and Fred releases the cast and crew to make final preparations for the opening night performance.

In the next scene, we see Lois as she searches backstage for Bill asking cast and crewmembers if they have seen him. Bill arrives "a prisoner of the yellow cab company" and tells Lois that he was gambling and signed a \$10,000 IOU in Fred's name. Lois scolds him for doing so singing "Why Can’t You Behave?"

Now the audience gets to peek inside Fred and Lilli's adjoining dressing rooms as they prepare for opening night. They continue to bicker with Fred, upset that Lilli has called him "a bastard" in front of the cast. As they bicker Lilli reveals her engagement ring and tells Fred that she is engaged to an important military official. She then reminds Fred that it is the anniversary of their divorce and gives him back the cork from the bottle of champagne they shared the first morning they were married. The mood shifts and the two former lovers begin to fondly remember the operetta in which they were both performing when they met. An operetta "set in Switzerland, but the costumes were Dutch" which included a Viennese waltz entitled "Wunderbar". They sing and dance reminiscing on the days they were in love. This loving 
moment is cut short as the stage manager, Ralph, interrupts to let them know they have 10 minutes until they must be in their places for the start of the show. Fred retreats to his dressing room to finish his preparations and is greeted by two gangsters who have come to collect the $\$ 10,000$ IOU. Fred insists that he did not sign it and the gangsters excuse themselves to their box seats to allow Fred to jog his memory threatening to return later for the money.

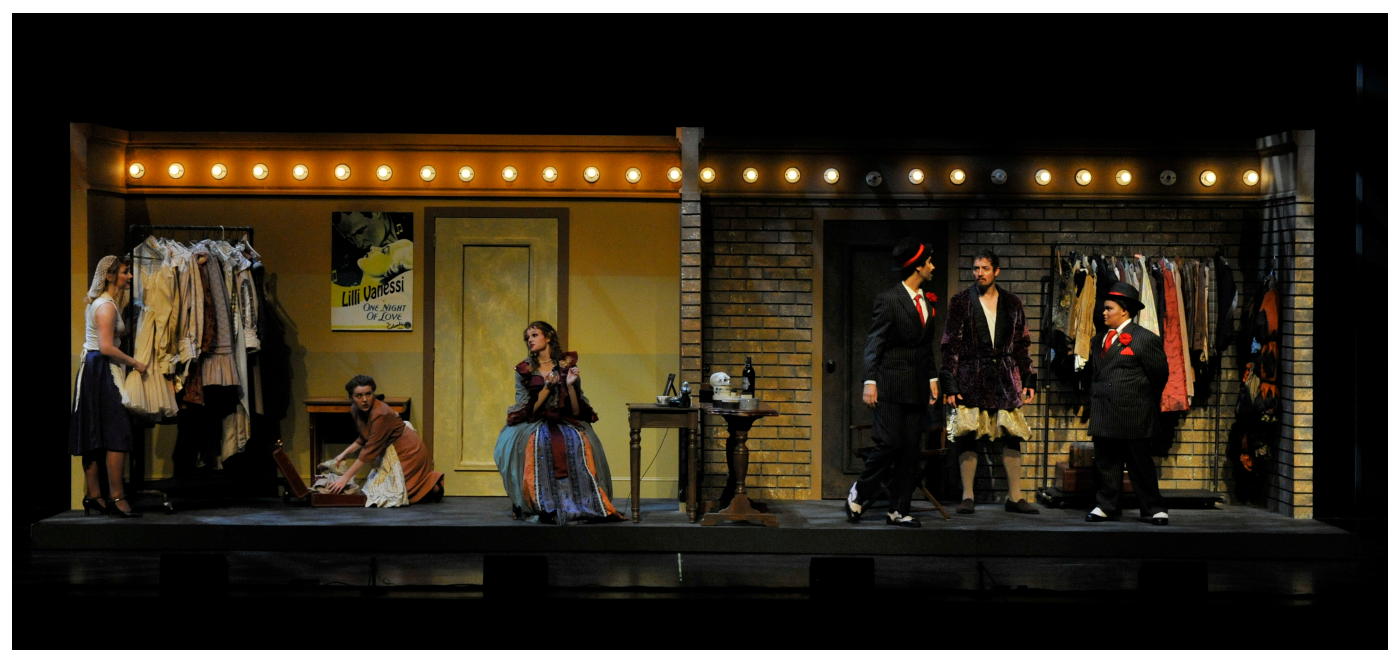

Figure 2: Lilli and Fred's Dressing Rooms.

Lilli receives a bouquet of flowers from Fred that are the same flowers as her wedding bouquet. The audience gets to see Lilli's feelings as she reveals that she is still in love with Fred as she sings the beautiful song "So in Love". When Fred realizes that Lilli has received the bouquet that he intended for Lois he tries to prevent Lilli from reading the card accompanying the bouquet. Lilli snatches the card back from him tucking it into the bodice of her gown for good luck while stating that she will read it later.

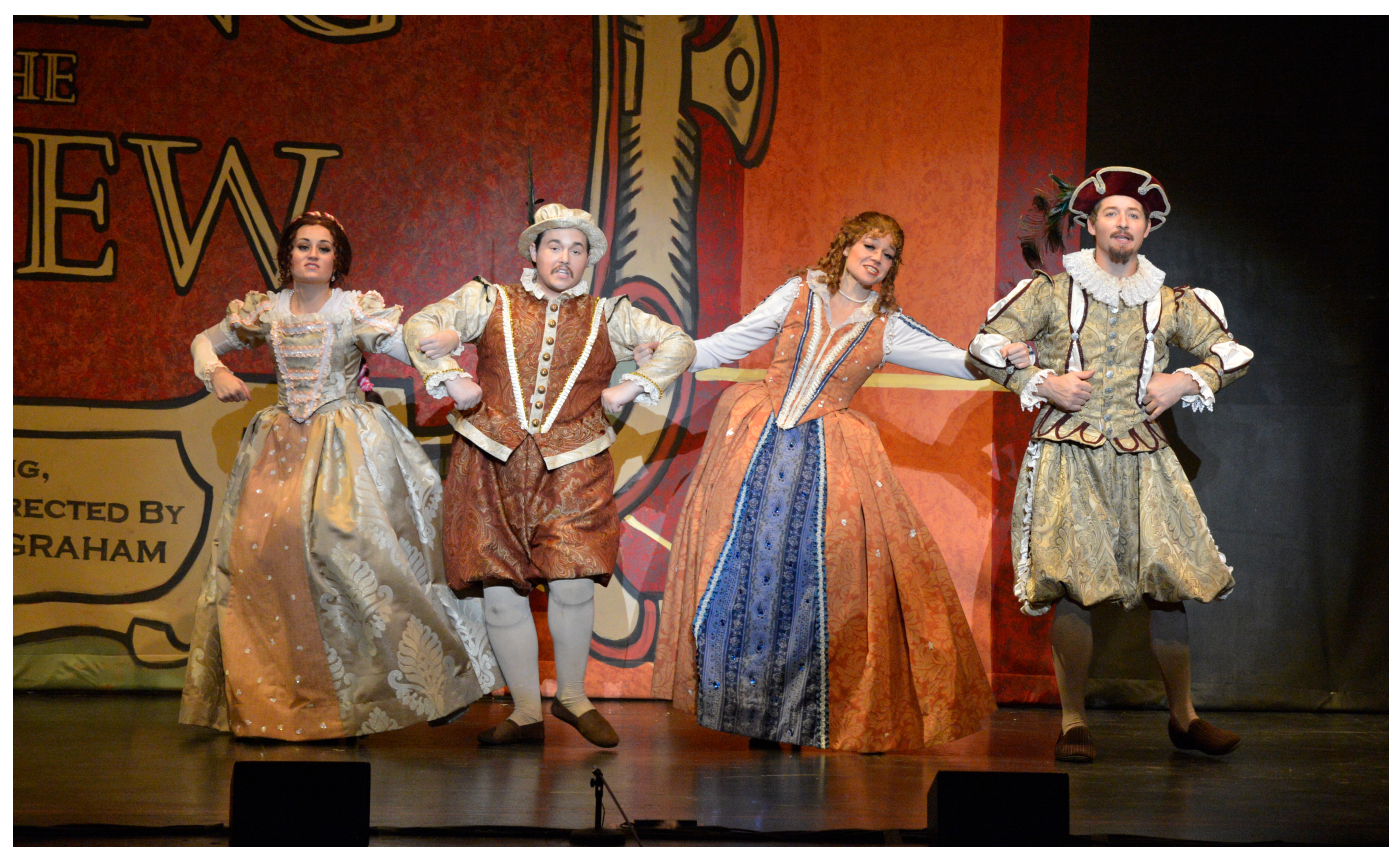

Figure 3: "We Open in Venice." 
The show within the show opens with the bright song "We Open in Venice" as we see Lilli, Fred, Lois, and Bill dressed now in their Elizabethan costumes. The curtain is then raised to reveal Baptista's courtyard as we see wealthy landowner Baptista explaining that he will not allow Bianca to marry until his older daughter Katherine is married. There is one problem with this arrangement, Katherine is ill tempered and shrewish, and because of this no man will marry her. As Baptista and Katherine retire to the house, three of Bianca's suitors (Lucentio, Hortensio, and Gremio) express their desire to marry her. Bianca and the suitors sing and dance to "Tom, Dick, or Harry" during which she says that she would marry any of them. The suitors then compete amongst themselves for her hand, with Lucentio beating out the other two for Bianca's affection.

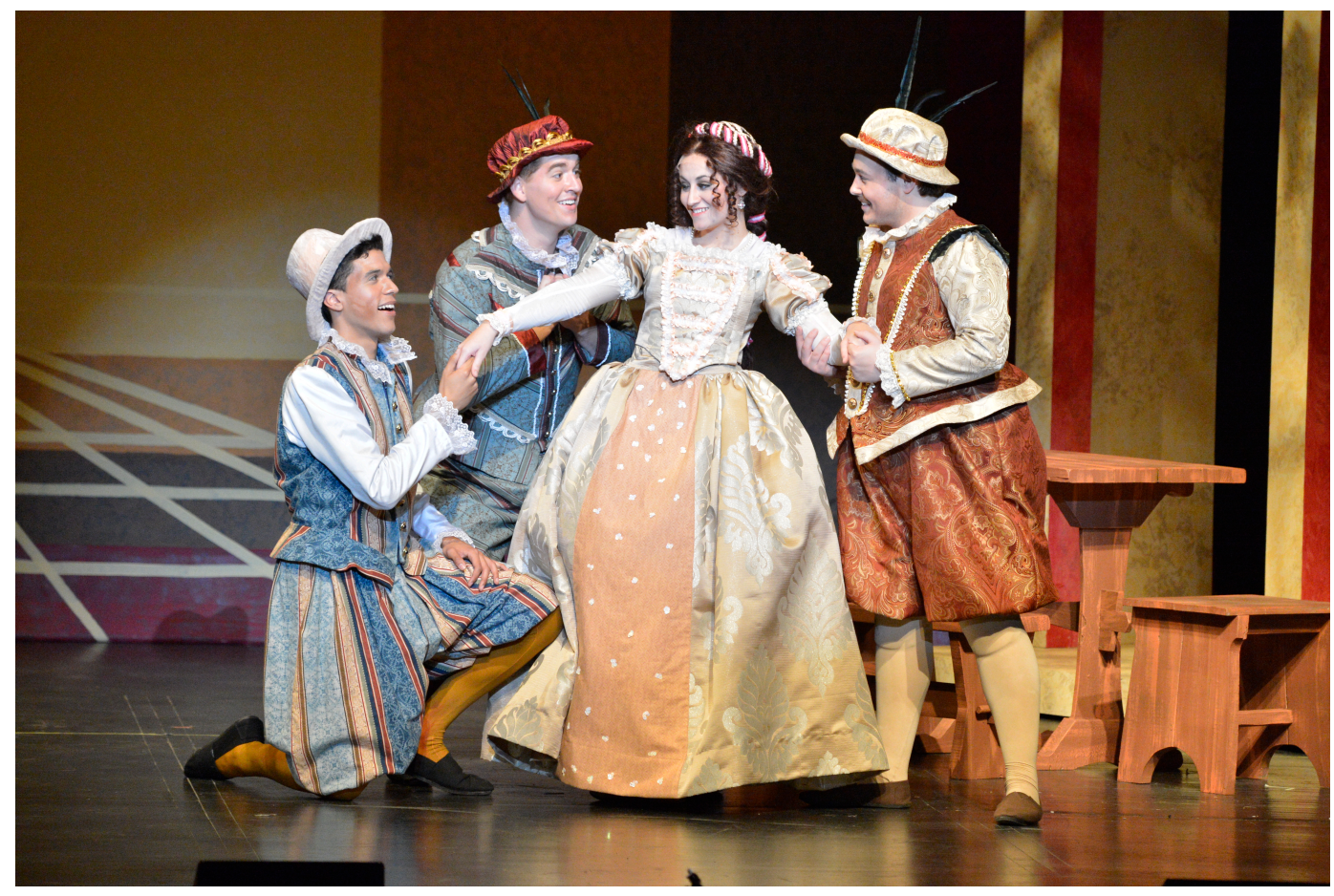

Figure 4: Bianca and her suitors.

As Bianca retires into Baptista's house a newcomer arrives to town. Petruchio has "come to wive it wealthily in Padua." As Petruchio sings the three suitors hatch a plan. They will convince Petruchio to marry Katherine leaving Bianca open for marriage. They pull Petruchio aside to tell him of Katherine, a wealthy maiden for him to wed. However, we discover Katherine has no intention to marry as she sings "I Hate Men". Petruchio meets Baptista and tells him of his intent to marry Katherine, and Baptista sends Katherine out to meet Petruchio. Petruchio sings to Katherine and in a moment offstage Lilli reads the card that accompanied her bouquet revealing the intended recipient. She returns to stage and begins to berate and hit Fred as he and the other actors attempt to stay in character. As Baptista gives his permission for Petruchio to marry Katherine, Lilli continues to strike Fred prompting him to spank her. The cast and crew scramble to cover up this break in character as the drama moves backstage. 
Lilli storms through the backstage to her dressing room and declares that she is leaving the show. She calls her fiancé and tells him that he should come collect her from the theatre. The gangsters reappear in Fred's dressing room and he decides to use this moment to keep Lilli at the theatre. He informs them that if Lilli leaves he will have to close the show and he will not be able to repay the $\$ 10,000$. The gangsters then go into Lilli's dressing room and force her to stay at gunpoint.

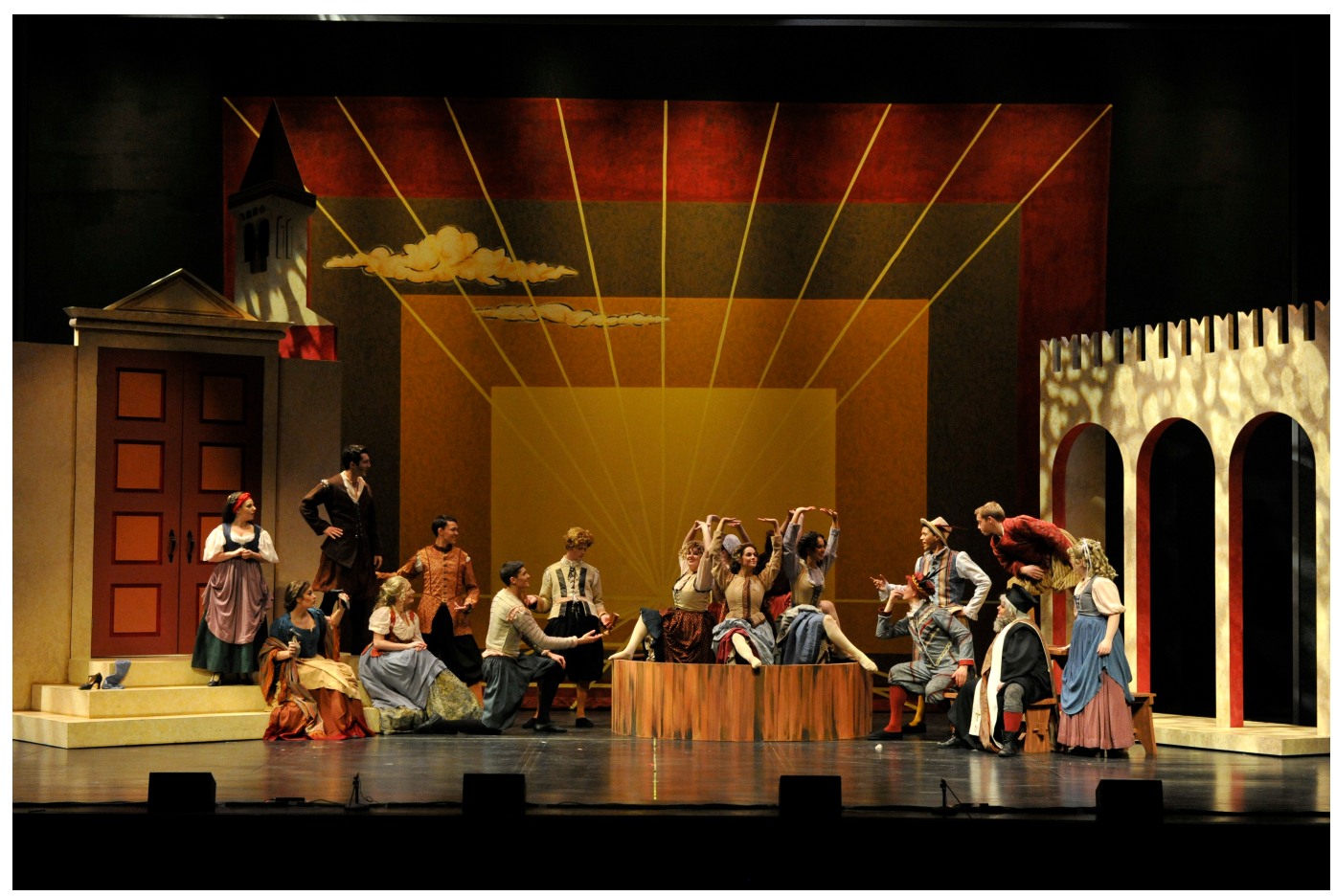

Figure 5: The ensemble dances during "Cantiamo D'Amore."

Back on stage the chorus dances and stomps grapes into wine as they sing of love in front of the church where Katherine and Petruchio's wedding is taking place. As Katherine and Petruchio exit the church and join the festivities they are followed by the gangsters, now in Elizabethan costumes, making sure that Lilli does not try to escape. While the ensemble sings the big Act One finale number "Kiss Me Kate" Petruchio implores Katherine to kiss him and when she refuses, the gangsters drag her offstage ending Act One.

Act Two begins in a backstage alley when the cast and crew have gathered during intermission to relax and catch their breath as they sing, dance, and lament that it's "Too Darn Hot."

Meanwhile the show continues onstage. Katherine and Petruchio have arrived at Petruchio's home with the two gangsters still in tow. Petruchio tries to continue to tame Katherine but she locks herself in a room. As this happens Petruchio mourns for his now-lost bachelor life and sings "Where is the Life that Late I Led?" 


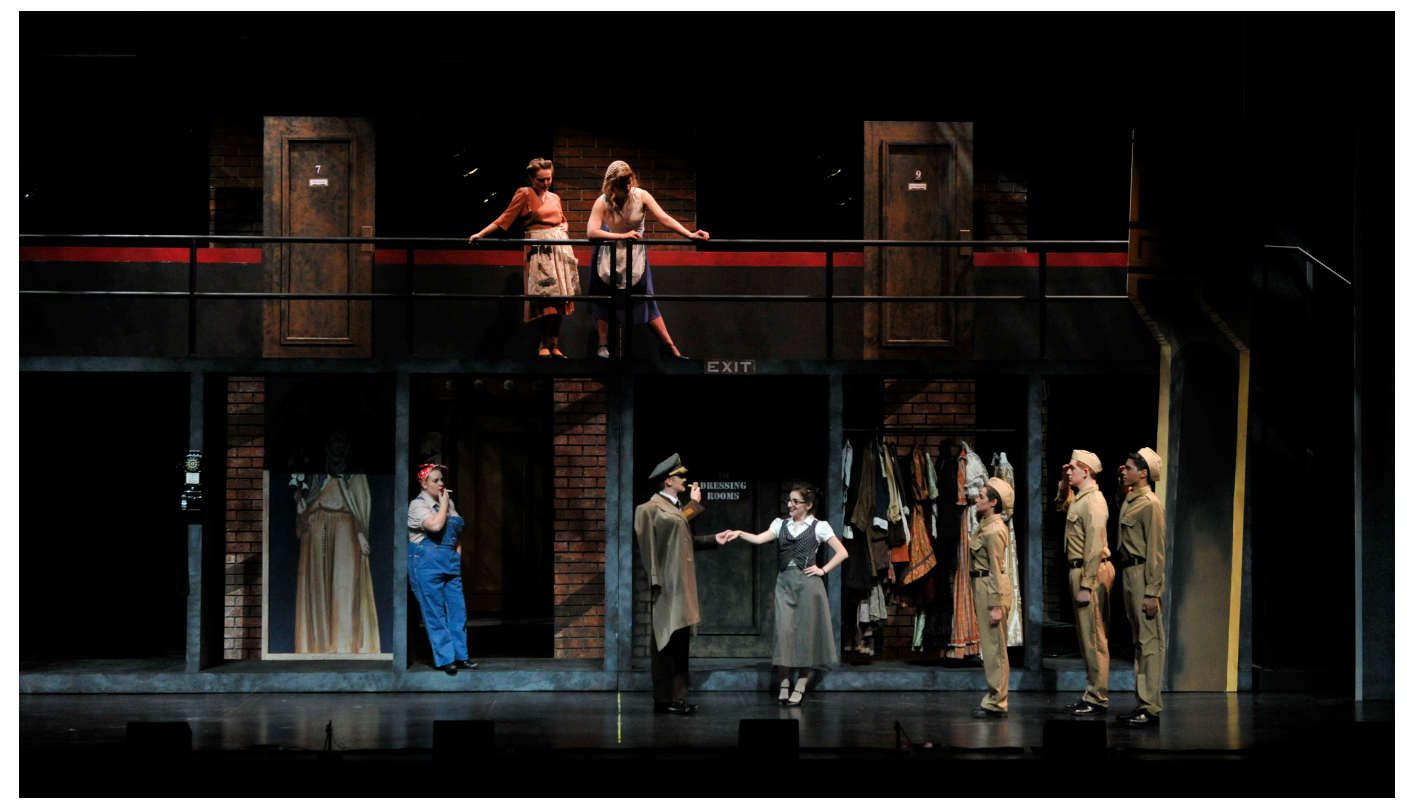

Figure 6: General Howell is greeted backstage by Ralphie the Stage Manager, played by Katie Boothby.

Backstage, Lilli’s fiancé, General Harrison Howell, has arrived with sirens blaring to rescue Lilli. As he arrives he bumps into Lois who recognizes him as one of her former lovers, Howell makes her promise not to tell and says that she should get in contact with him in about six months. Bill overhears this and is shocked, Lois sings to him that even if she is with other men that she is "Always True to You in My Fashion.” In Lilli's dressing room we find General Howell making plans for his wedding to Lilli. When Lilli comes in exasperated from the events that have unfolded onstage she tries to tell him that she is being forced to stay by gangsters. However, General Howell doesn't believe her and thinks she is trying to play a joke on him. Fred then points out sarcastically how exciting her new life will be, playing the quiet wife of a military man, compared to the glamour and fame a life in theatre holds. Next we see Bill backstage with some of the stagehands and wardrobe ladies, they poke fun at him about how Lois is not completely faithful to him. He then sings "Bianca", a song that he has written about how much he loves Lois. Meanwhile, the gangsters get a phone call from their new boss "Mr. Gumpy" informing them that their old boss has been killed, voiding the $\$ 10,000$ IOU. They say their goodbyes to Lilli and Fred and leave to return their Elizabethan costumes. Fred tries, unsuccessfully, to get Lilli to stay but she refuses leaving the theatre after General Howell. After Lilli leaves, Fred is left alone and sings about how he is "So in Love" with her.

As the gangsters attempt to leave they get caught onstage and improvise a song in tribute to Shakespeare called "Brush Up Your Shakespeare." Through the words of the song they tell the audience that knowing Shakespeare is the key to romance. 


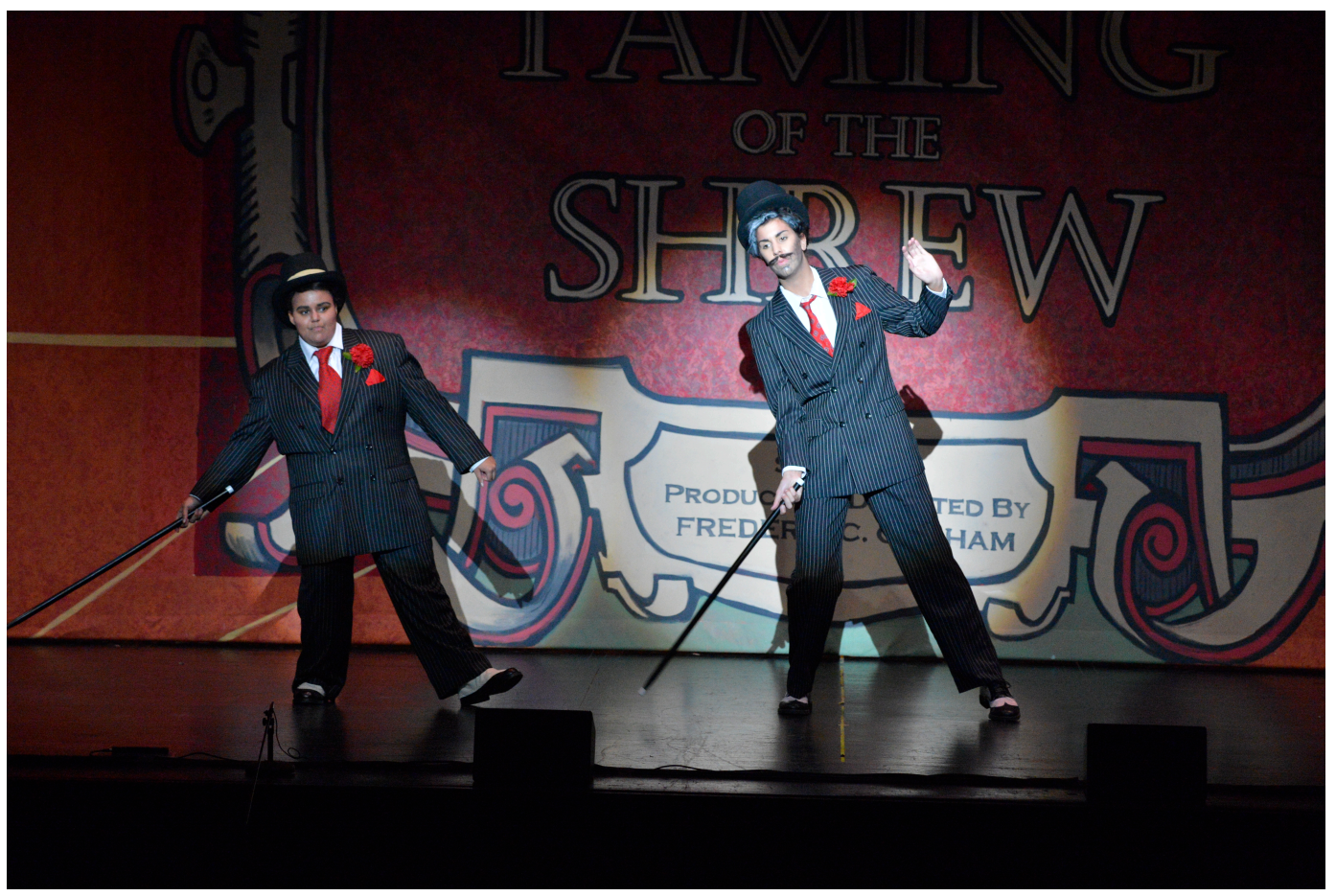

Figure 7: The two gangsters during "Brush Up Your Shakespeare."

On stage the company prepares for the conclusion of the show unaware that Lilli has left. We see Bianca and Lucentio exit the church after their wedding and Baptista implores Petruchio to tell him where Katherine is. Lilli returns just in time to deliver her last song "I Am Ashamed that Women Are So Simple." She does her best to reconcile with Fred as she sings. The show ends with a rousing reprise of "Kiss Me Kate" this time with Katherine and Petruchio kissing, as the gangsters, who have stolen the donkey costume, prance onstage chased by stagehands.

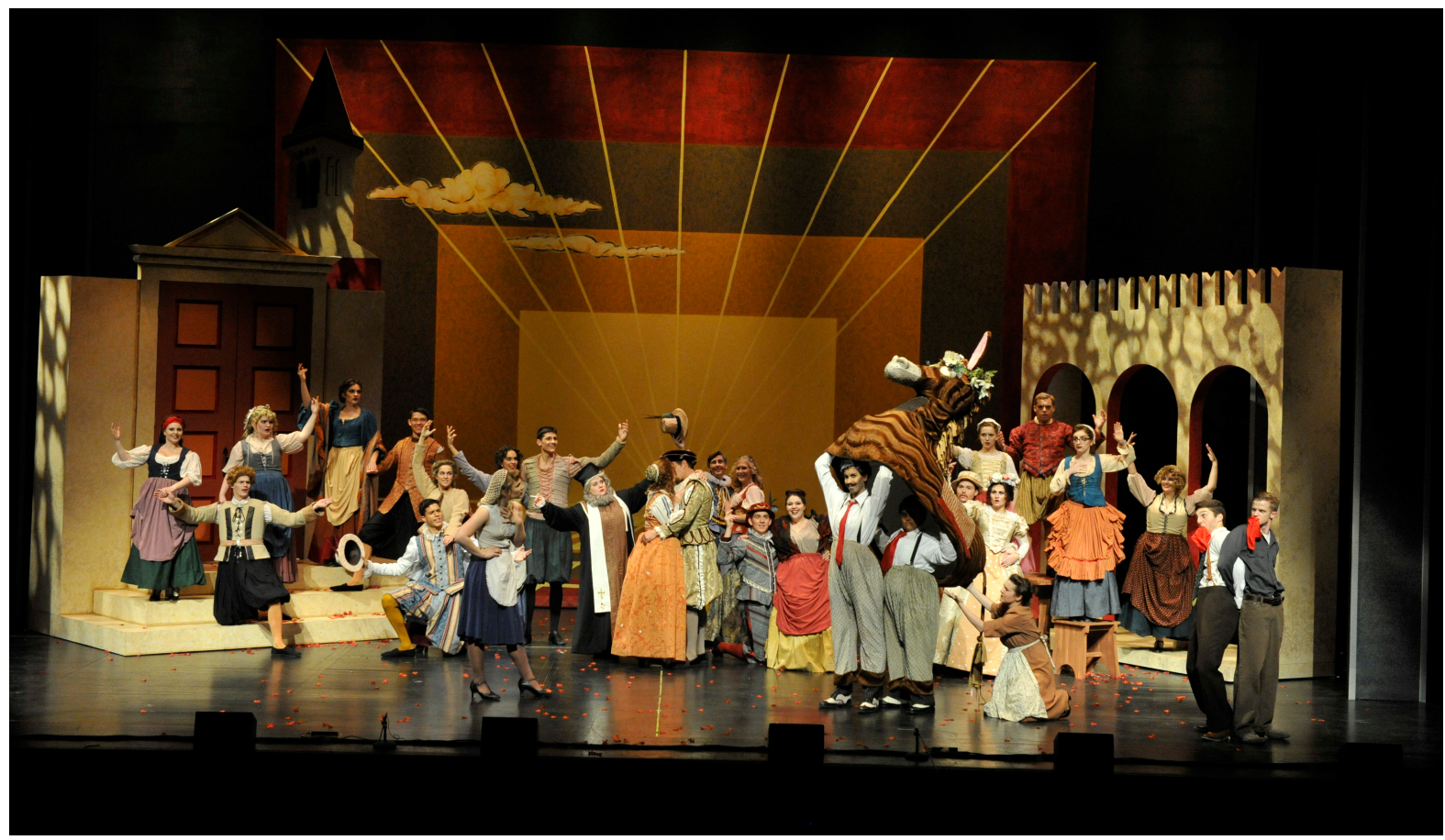

Figure 8: Finale. 


\section{Background on Kiss Me Kate}

In the mid 1940s Producer Arnold Saint Subber approached playwright Bella Spaweck to write the book for a new musical based on his experience working on The Taming of The Shrew years earlier. While working as a stagehand on the Broadway production he witnessed the stars, husband-and-wife acting team Alfred Lunt and Lynn Fontanne, carry their on-stage arguments into their real lives as they continued fighting backstage. Bella Spewack then approached Cole Porter to write the music and lyrics. Initially Cole Porter was reluctant to the idea of turning Shakespeare into a musical thinking that it was “too highbrow." Luckily Bella Spewack persisted and Cole Porter was convinced. Cole Porter became fascinated with the two opposing levels of reality; the real lives of the actors backstage and the lives of Shakespeare's characters onstage, and how events onstage start to influence behavior offstage and vice versa. After working with Cole Porter on the script Bella Spewack felt that the structure was lacking and called in her estranged husband, Samuel Spewack, to assist them. The show opened on Broadway in 1948 wowing audiences and critics, and in 1949 was awarded the very first Tony Award for Best Musical. Additionally the show won Tony Awards for Best Author, Best Original Score, Best Costume Design and Best Producer of a Musical. In 1951 Samuel Spewack restaged the production at the London Coliseum, and in 1953 it was turned in to a film starring Howard Keel and Kathryn Grayson. A major Broadway revival was staged in 1999 winning a Tony Award for Best Musical Revival, Best Actor in a Musical, Best Direction of a Musical, Best Orchestrations, and Best Costume Design.

\section{Cole Porter}

Cole Porter was born in 1891 in Indiana. From a young age he proved to be a talented musician, learning the violin and piano and composing his first operetta (with the help of his mother) by the age of ten. Porter studied English, Music, and French at Yale University. While at Yale he wrote six full-scale musicals. After his grandfather's insistence he transferred to Harvard to study law, but in his second year decided to study music instead. Cole Porter quickly became moderately successful as a composer and abandoned his studies to move to New York City to focus on his growing career. However, after his first Broadway show ended as a critical and commercial flop he moved to Paris to live among the French aristocracy. While in Paris, Porter met rich divorcee Linda Lee Thomas, whom he eventually married. Linda Lee Thomas encouraged Cole Porter to focus on writing classical music but he continued to compose music in a variety of styles. In 1928, Paris, a Broadway musical Cole Porter wrote a majority of the music for opened to great success and shortly after was adapted into a movie. Collaborating with P.G. Wodenhouse and Guy Bolton on Anything Goes secured his place as one of the most prolific songwriters of his generation. In 1937, Cole Porter was involved in a horse-riding accident which left him wheel-chair 
bound for the rest of his life. He continued to write songs for several more shows however; none of them were nearly as successful as Anything Goes until he teamed up with Sam and Bella Spewack for Kiss Me Kate. Cole Porter passed away in October 1964 after suffering from kidney failure.

\section{Sam and Bella Spewack}

Samuel Spewack was born in the Ukraine in 1899, and Bella Cohen was born in Bucharest in the same year. While young children both immigrated to New York with their families. After completing their schooling, they both began to pursue careers as journalists. In 1921 their paths crossed and they were married the following year and began working together as foreign correspondents, moving to Moscow. In 1926 they moved back to the United States and settled down in Pennsylvania and began writing comedies together. Many of these plays were performed on Broadway, and in 1938 they worked with Cole Porter to adapt one of their plays, Clear All The Wires, into a musical that they titled Leave It To Me! Bella Spewack and Samuel Spewack were separated following a major marital dispute when Bella Spewack was approached by producers Arnold Saint Subber and Lemuel Ayers to write the book for Kiss Me Kate, however they put aside their differences to work on the show and rekindled their relationship when the show opened in 1948. The Spewacks continued to write together and individually however they never wrote another show as successful as Kiss Me Kate. Both stopped writing in the mid-1950s, and following Samuel Spewack's death in 1971 Bella Spewack spent her time travelling the country to see various regional productions of Kiss Me Kate until her death in 1990. 


\section{Design Concept}

Our production's director, Professor Britton, expressed his desire to create a "technicolor dreamland" for our Elizabethan Renaissance show within a show. Professor Klingelhoefer, the scenic designer, discussed the need for a duality between the two halves of the show. We decided to go forward with an idea that the show-within-the-show is bright and colorful while the backstage areas are darker and duller with lots of shadows. It was this idea that pushed me to focus on bringing lots of bright, rich colors and patterns into my designs for the show-within-the-show while choosing more neutral colors for the backstage characters to allow them to fade into the background when needed. From working previously in the Lyell B. Clay Theatre I knew that choosing fabrics with patterns or prints would create more interesting looking costumes. For example in Figure 10, Bill (center) is in his Lucentio costume and the ladies surrounding him are in their 1940's costumes. Bill's Lucentio costume is a rich red/orange color while the women are in navy, light blue, and faded pink, this allows Bill to pull the focus of the audience while still balancing with the women. Additionally, there is a slight pattern to Bill's costume as well as the skirt and dress of the two women on the right side of the photo. These patterns add an additional dimension to the clothing. In the initial design process after Professor Britton and I looked at the what the script called for and how many additional ensemble members he would like, we discussed how many actors he would cast and settled on a number of no more than thirty total.

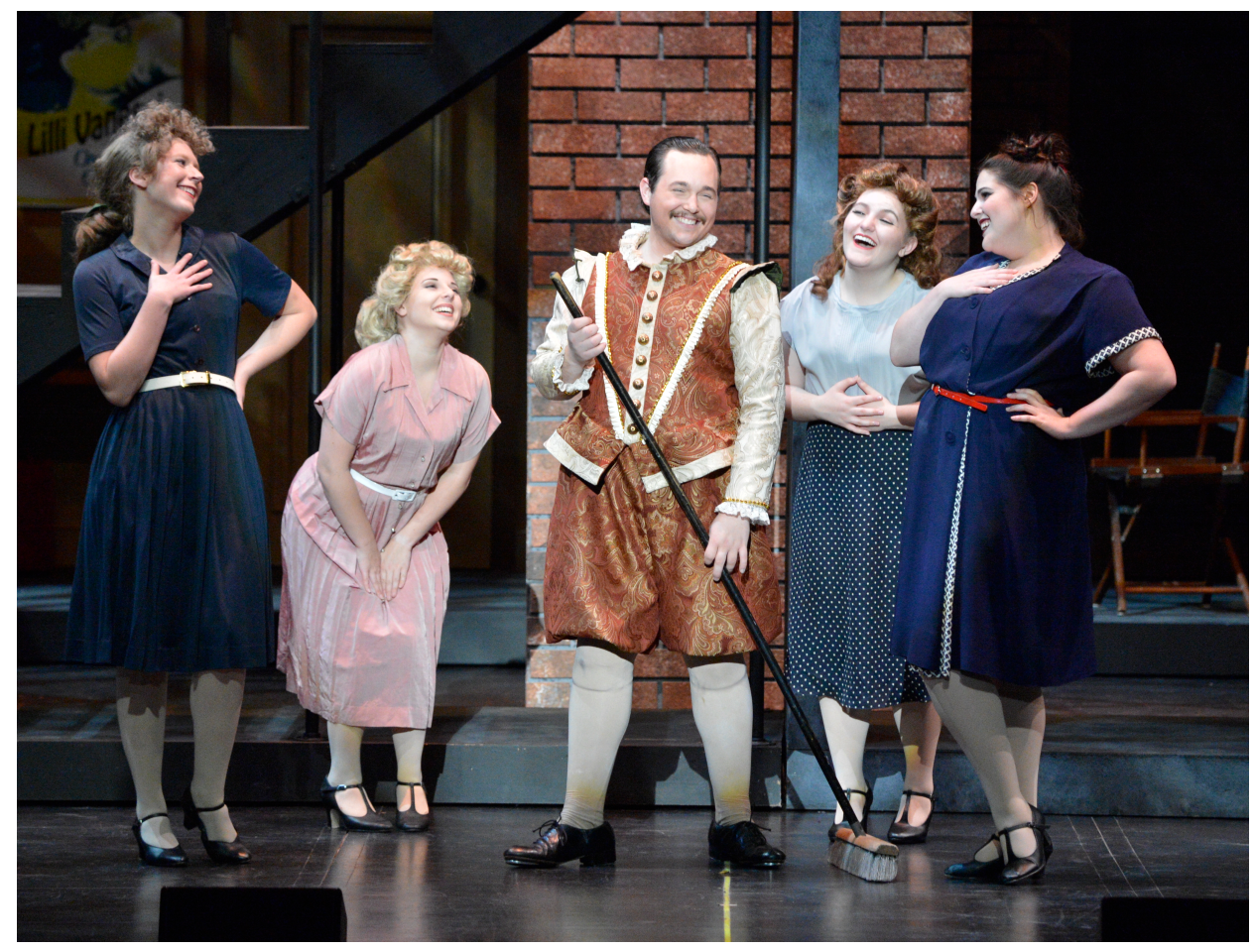

Figure 9: Bill and some of the ensemble women. 


\section{Research}

As I began the design process for this show in April 2015, I was finishing the build and involved in technical rehearsals on the show I was assigned to design for the spring semester, Mother Courage and Her Children. Because of this I felt like I was behind with getting my initial ideas and impressions of the show onto paper. Once I was able to begin working I created a Powerpoint outline with a page dedicated to each character. I drew on research from the 1940s looks for each character (See Appendix A). Luckily, earlier that year I designed costumes for Kurt Weil's opera Street Scene which is set in 1940s New York so I already had a considerable amount of research accumulated (See Appendix B). Some additional research was needed for the Baltimore stagehands and actors from the 1940s. Most of my research efforts were put into the Elizabethan clothing. I wanted to have a firm grasp on the Elizabethan period silhouette before I began conceptualizing design for the costumes for the show-within-the-show. For the people of Padua I drew much of my inspiration from Joachim Beuckelaer's market paintings. I loved his use of earth tone colors and layers of clothing.

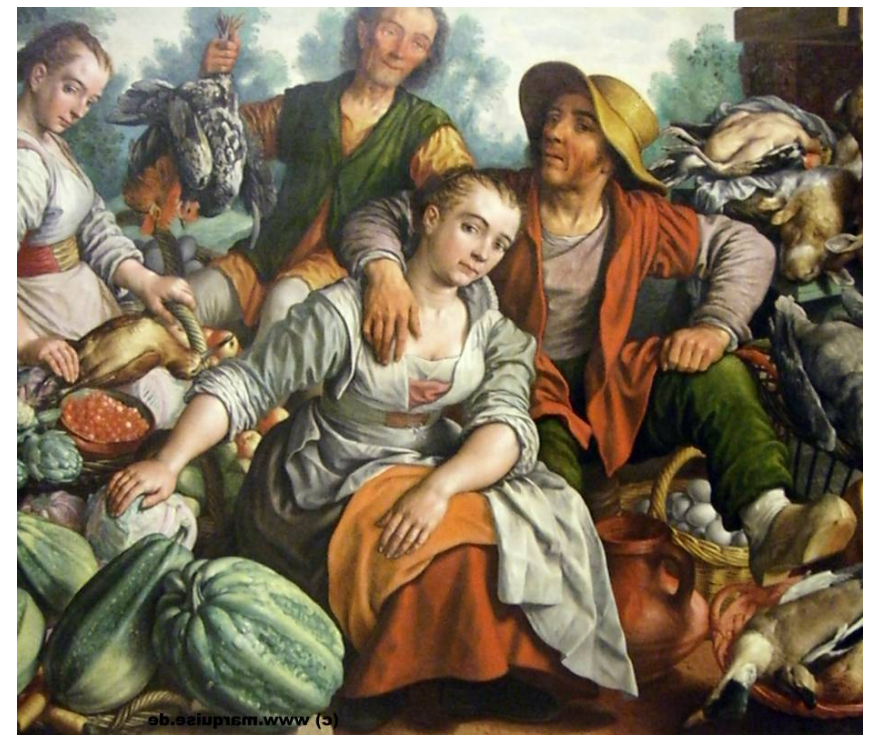

Figure 10: Country Market, Joachim Beuckelaer.

Through this I aimed to create a division between the classes. I costumed the upper class characters in bright rich fabrics with lots of trim and accoutrements while the lower classes had more natural fabrics in earthen tones with fewer details. 


\section{Character Breakdown}

\section{Lilli Vanessi:}

For Lilli's costume I desired to portray her in a fabulous movie star fashion. I wanted her to walk onstage and immediately have all eyes on her. In search of inspiration for this look I researched vintage patterns and images of 40's movie stars, Joan Crawford in particular, because I felt that her career paralleled Lilli's. Ms. Crawford started out in travelling theatre companies and as a chorus girl on Broadway then made the jump to motion pictures. I decided to give Lilli a sleek asymmetrical dress with dynamically draped areas. To help pull focus to her this dress was in royal blue crepe-back satin. After a suggestion from Director of Costumes Mary McClung I decided to give her a luxurious fur wrap. Additionally, I gave her lots of jewelry and large rhinestone buttons so that she sparkled like a diamond on stage. For Lilli's hairstyle I wanted her to have a polished "up-do" with a small wave that we could add a sparkly hair accessory to. When Lilli is dressing for the show in her dressing room I designed a long robe for her to wear over the skirt of her Katherine costume to make the quick change into the Katherine look function more efficiently.

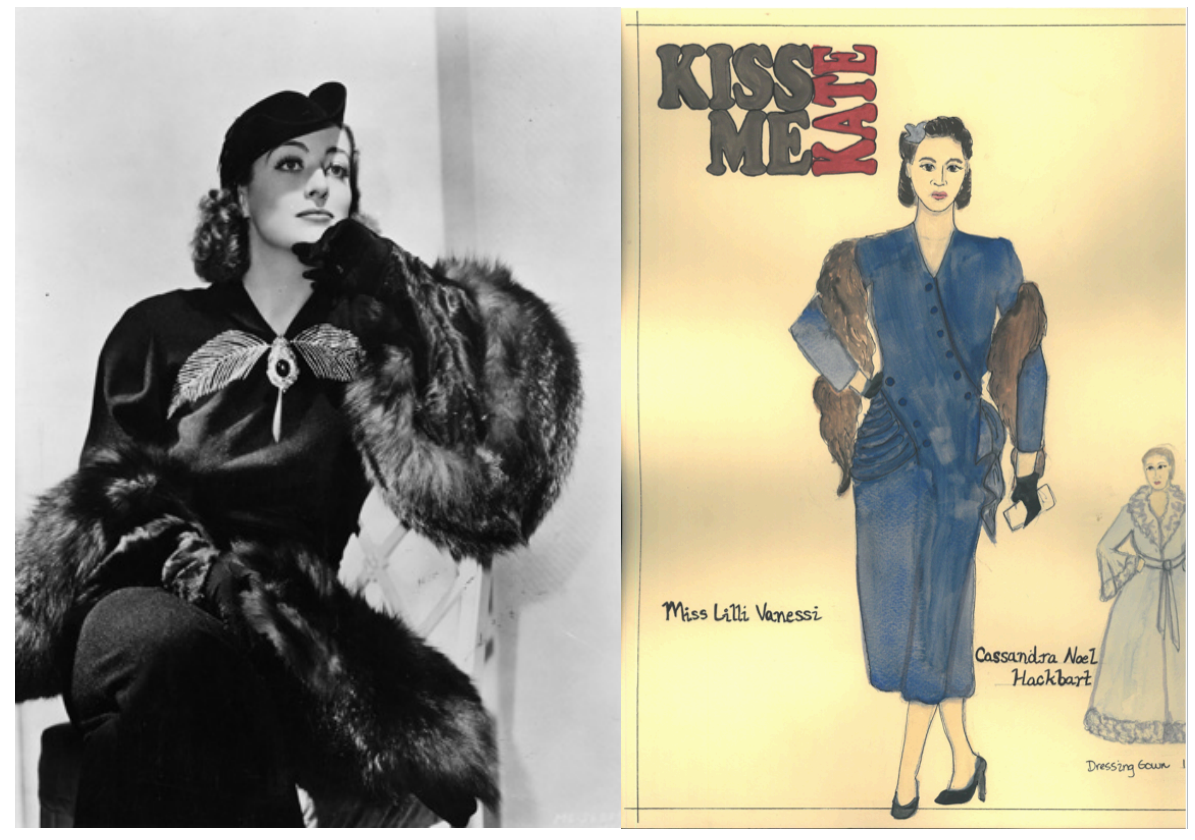

Figure 11: Joan Crawford, actress.
Figure 12: Rendering for Lilli Vanessi.

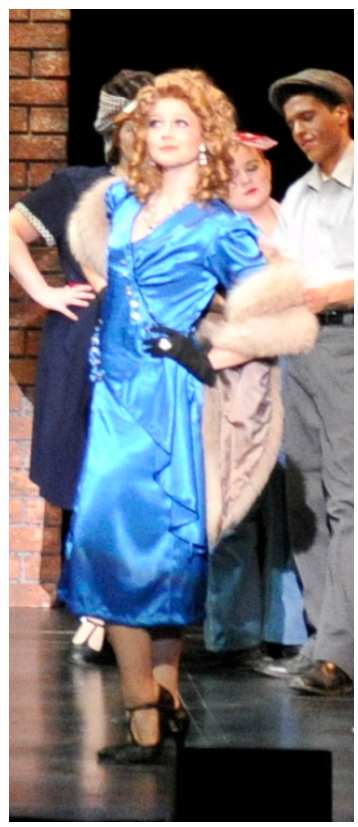

Figure 13: Lilli’s Costume 
Katherine:

For Katherine's costume (played by Lilli Vanessi) it was my desire to demonstrate that she was from an affluent family but that she also was not as interested in fashion as her younger sister Bianca. This is what drew me to the portrait of Isabella De'Medici, I loved the long clean lines of the bodice as well as the simplicity of the garment. There are some trim details in moderation. Because of this image I initially wanted to put her in black and dark red however Professor McClung, who has plenty of experience designing on the large Lyell B. Clay stage recommended that black would not be a good idea because she would disappear from focus due to the amount of color I was using in the ensemble character's costumes, also because the show is a musical comedy. After some thought I decided to put her in coral tones with blue accents to connect to her Lilli costume, this way the audience could visually match her throughout the show. For Katherine's hair I wanted something true to the period so I designed a look for her with the bulk of her hair pulled back in an openwork lace bonnet (similar to the one in the portrait of Isabella De'Medici) with a few curled tendrils around her face to soften the look slightly. When it came time for her wedding at the end of Act I, I felt that Katherine as a character would be very opposed to dressing up for a wedding that she opposed to show this I gave her an ivory satin Elizabethan Attifet hat with ivory lace and a veil. I wanted this hat to seem very out of character for her and for her to seem very uncomfortable wearing it.

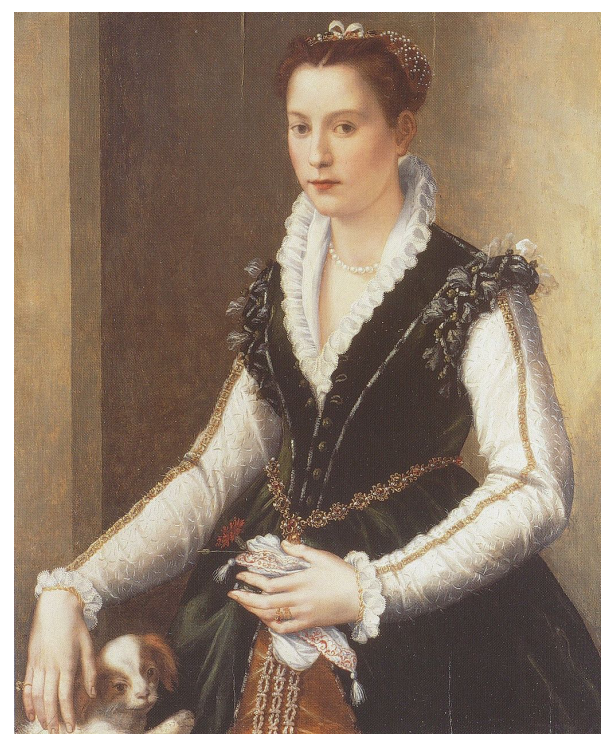

Figure 14: Portrait of Isabella De'Medici.

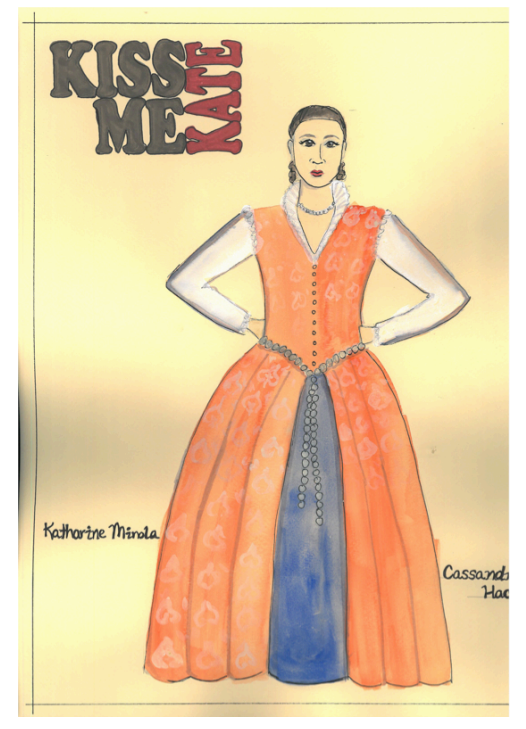

Figure 15: Final Rendering of Katherine's Costume.

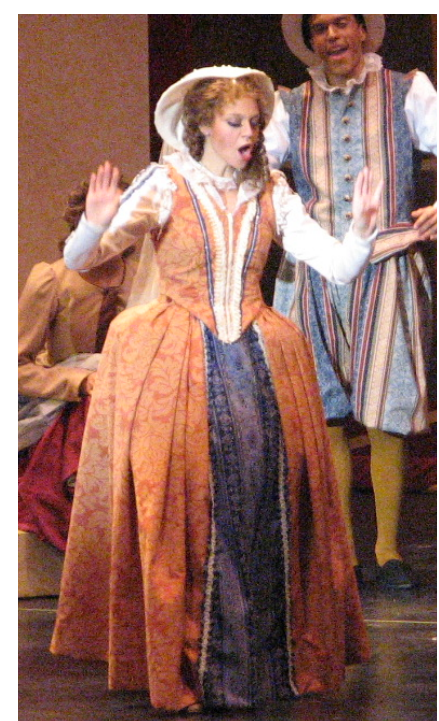

Figure 16: Katherine's Wedding Look. 
Fred Graham:

Fred Graham was an interesting character to costume, because I felt that although he had put every last penny into mounting the production I still wanted him to look like he was wearing his best suit to try to impress Lilli. Because of his role as Lead Actor, Director, and Producer of the show I wanted him to be one of the most stylish men onstage. In my research I was drawn to the classic look of Cary Grant. I felt that borrowing his dashing good looks, debonair demeanor, and leading man charm were essential to creating the character of Fred Graham. I therefore decided to put him in a tailored gray suit. As a slight nod to Lilli's blue satin dress I gave him a dark blue tie and pocket square.

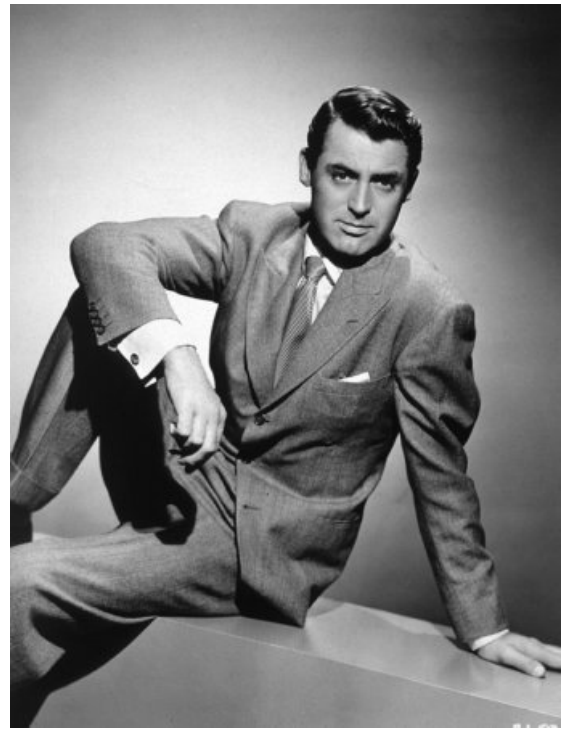

Figure 17: Cary Grant, Actor.

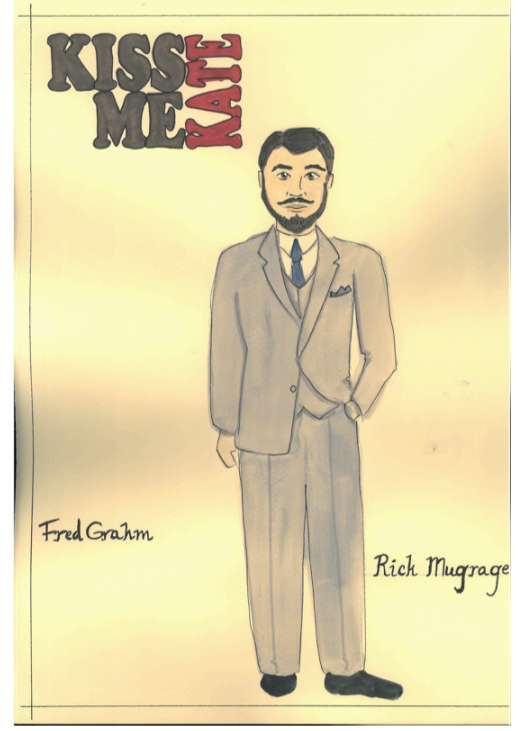

Figure 18: Final Rendering of Fred's Costume.

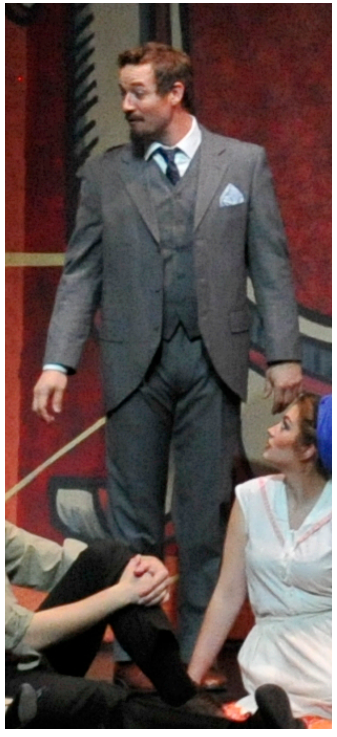

Figure 19: Fred's Costume. 
Petruchio:

As inspiration for Petruchio I turned to Elizabethan era portraits. The well-known portrait of Sir Robert Dudley by Steven van der Meulen (Figure XVII) captured the level of wealth and style I desired. Originally I designed a costume with lots of slashing and details, but after discussion with Professor McClung I decided to simplify the design and only have slashing on the sleeves of the garment. However, because graduate student Lauren Brennan, who was assigned to construct the costume, was able to construct the garment quickly she was able to apply topical patches that insinuated slashing on the body of the doublet. Petruchio's wedding look is a very important moment of The Taming of the Shrew, with his ridiculous outfit he is beginning to try to break Katherine of her unpleasantness. Shakespeare is very specific in his description of the look through other character's recollections and reactions. Because of this I felt that I needed to give a look similar to what the characters are stating about the look and then go over the top so that our modern day audience could relate with what the characters are reacting to.

Therefore I put him in mis-matched boots, very tight gold leggings with a very oversized cod piece, a blousy shirt that had a very deep opening in the front, a vest with lots of gold and red trim, a big "swishy" cape, and a hat with feathers so large that he could hit people with them as he turned his head.

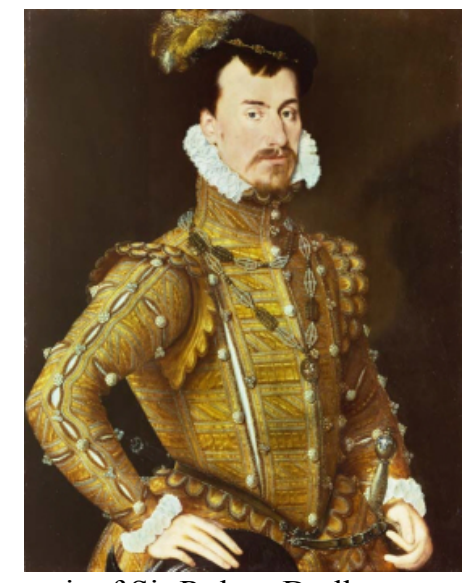

Figure 20: Portrait of Sir Robert Dudley.

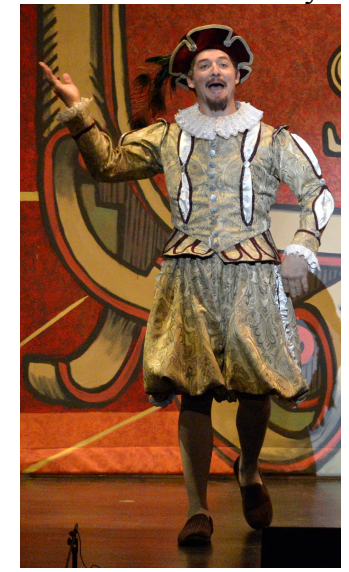

Figure 22: Petruchio's Costume.

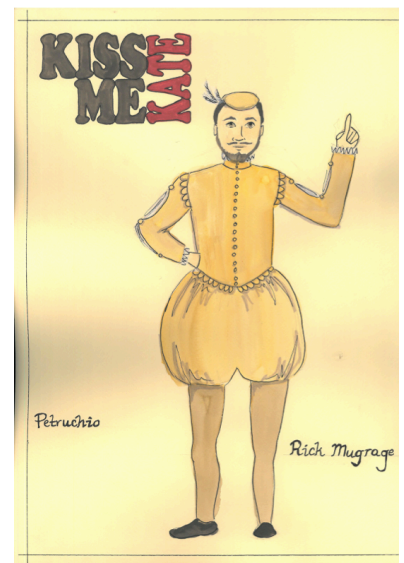

Figure 21: Final Rendering for Petruchio's Costume.

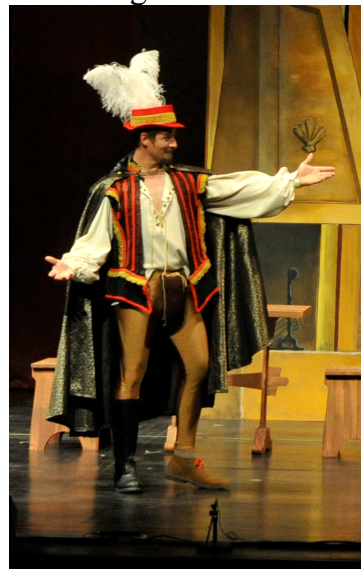

Figure 23: Petruchio's Wedding Costume. 
Lois Lane:

When it came to costuming Lois I wanted to make her very sexy and flirty to reflect her previous profession as a nightclub singer. To achieve this I gave her a sheer panel at the top of her bodice with sheer sleeves. I also gave her a peplum lined with a satin that could peek out as she danced. Initially I had only planned on giving her a slit up the back of her dress, but after seeing choreography for her in the opening number I decided that she needed additional vents up the sides to allow her full range of movements while dancing. To complete her look I designed Lois' hair down in loose waves with the front pulled back away from her face. This way she could play and flirt with her hair but the audience would never loose her facial expressions. After seeing this look on stage during the first dress rehearsal I decided that a line of sparkly trim needed to be added at the seam-line between the body of the dress and the sheer panels to help highlight it.

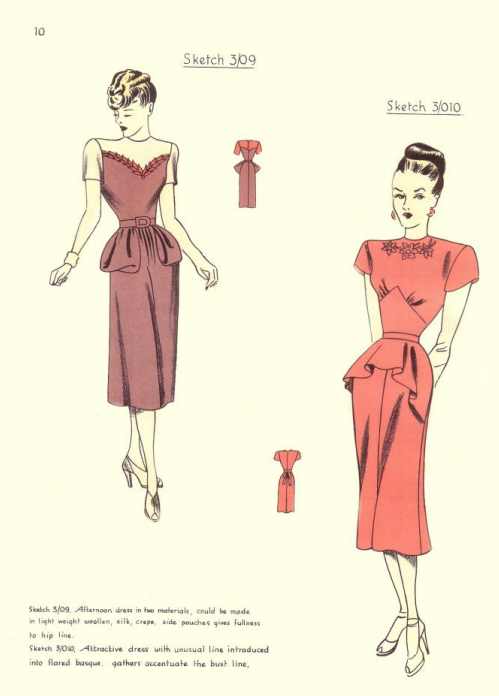

Figure 24: Fashion Design Image, Fashion-Era Women's Costume and Fashion History Blog.

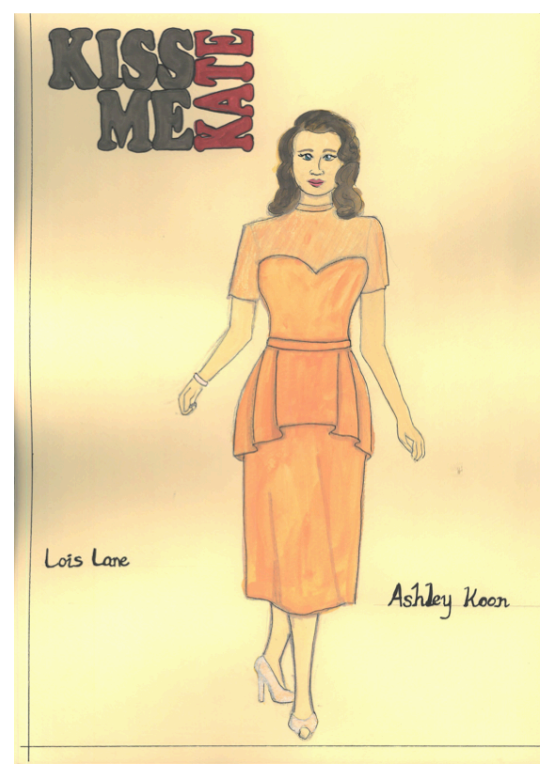

Figure 25: Rendering for Lois Lane.

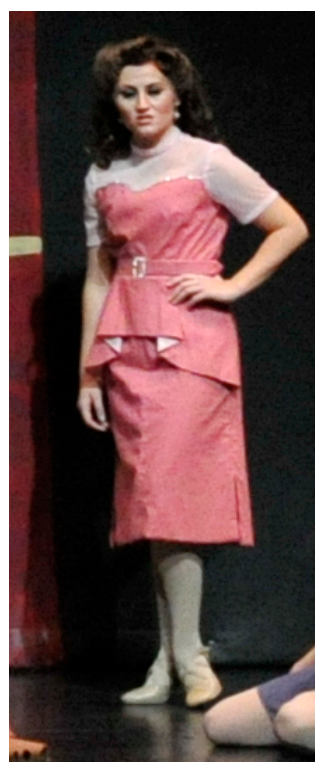

Figure 26: Lois’ Costume. 
Bianca:

With Bianca's costume I wanted to reflect youth and beauty, while still being a little sexy. To achieve this I decided to give her a lower cut bodice with a sheer partlet. This allowed her to show some skin without showing too much. To display her father's wealth I added lots of lace trim with plenty of sparkle. Initially I desired to put her in a white dress but concern was raised that her dress would pull so much light and focus that the audience wouldn't be able to look at anyone else. Therefore I decided to put her in a buttery gold dress. For Bianca's hair I aimed to give her a very romantic look to match her desire to be married. I designed her look to be pulled back with an openwork lace bonnet decorated with lace and pearls with a long braid down the back wrapped in ribbons. She also had small curled tendrils around her face. When Bianca married Lucentio at the end of Act II I decided to give her a floral wreath with a tulle veil. Additionally, because Lois (Bianca) was featured in the "Too Darn Hot" dance number I decided that in order for her to be able to dance and not worry about ripping her costume that she would remove her bodice and dance the number in a robe with a marabou trim and her skirt.

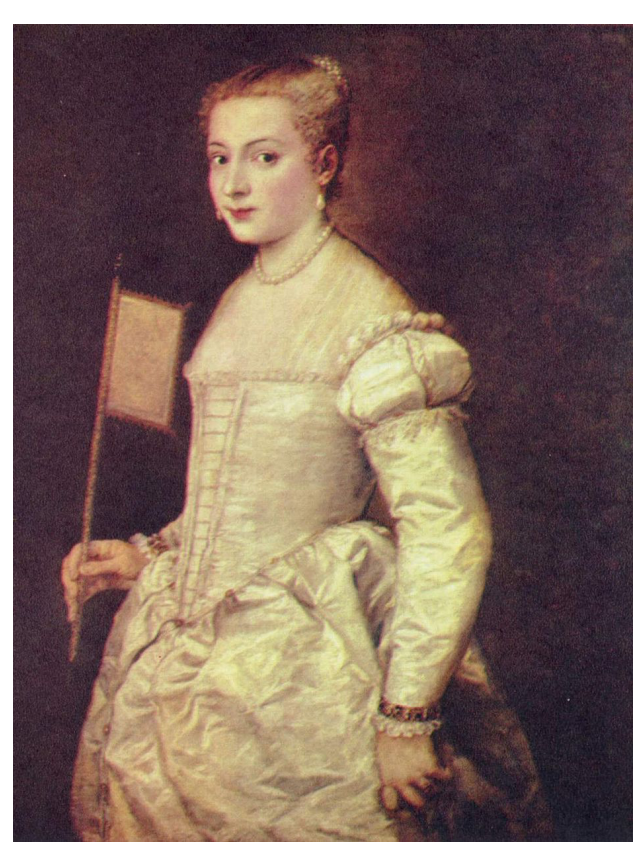

Figure 27: Portrait of a Lady in White.

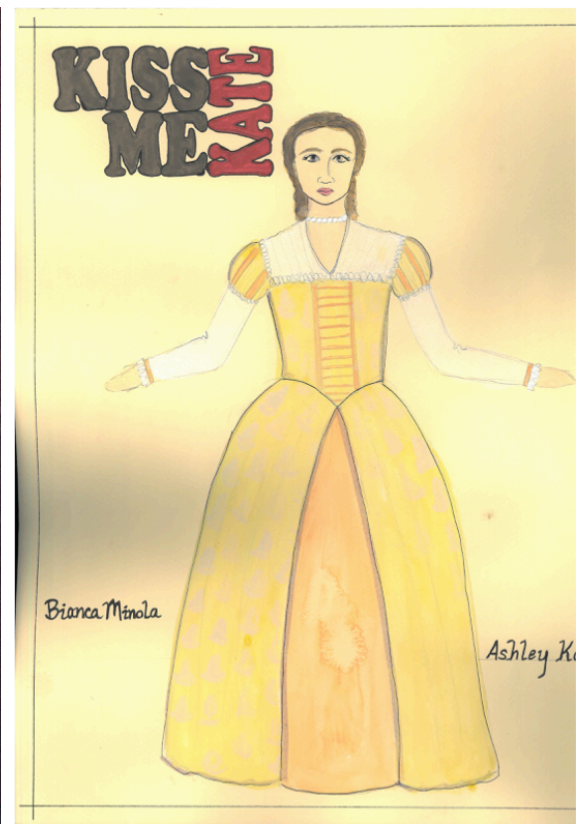

Figure 28: Final Rendering of Bianca's Costume.

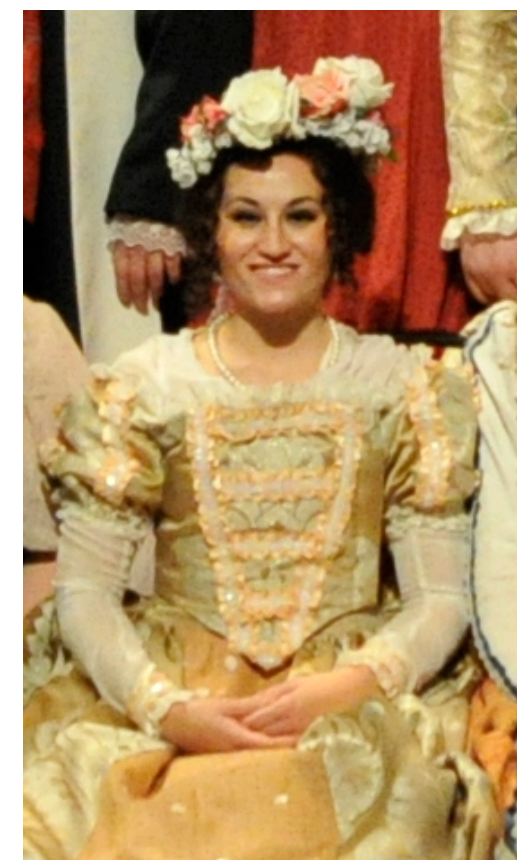

Figure 29: Bianca’s Wedding Look. 
Bill Calhoun:

The look I aimed to create for Bill Calhoun was one of a well-meaning but slightly slick gentleman. To do this I gave him a brown double-breasted suit. He also had a fedora that he carried in from the taxi. The actor playing this character was very detail oriented so it allowed us to add some small details in the final styling that the audience would not notice, but that made a big difference to him when he portrayed Bill. These details included giving him gold dice cufflinks and a gold tie clip

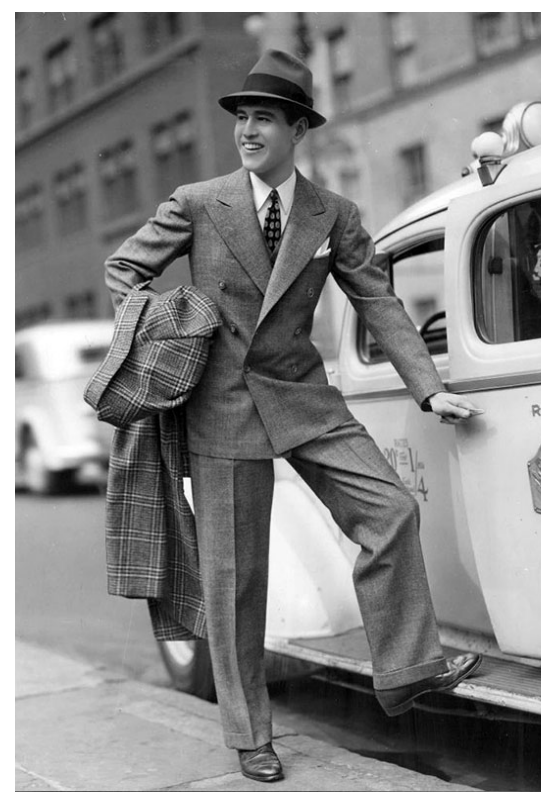

Figure 30: Man Getting into Taxi, A Decade in Fashion: The 1940's.

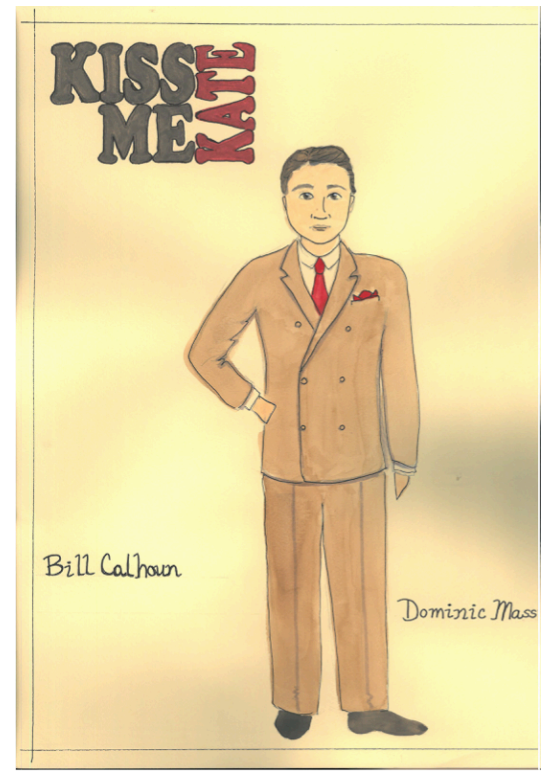

Figure 31: Final Rendering of Bill Calhoun's Costume.

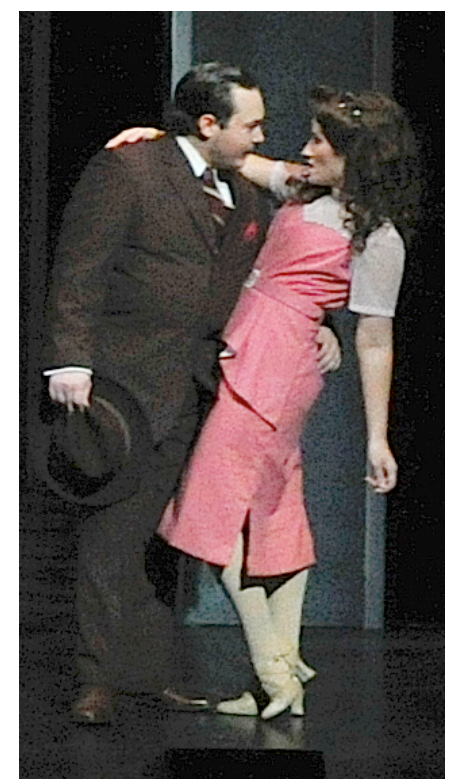

Figure 32: Bill and Lois. 
Lucentio:

Lucentio as one of Bianca's suitors needed to look wealthy, I aimed to achieve this by using gold and red with gold embroidery fabrics. After seeing the doublet in fittings I felt it needed another element so a sparkly trim that was added. Movement was key in this costume because Lucentio (Bill) has two large dance numbers; "Tom, Dick, or Harry" and "Bianca." To facilitate this his pumpkin breeches were built with lots of room in the inseam and gussets were added to the underarm seams of his doublet. Additionally, because he had many dance moves on his knees he desired to wear kneepads under his tights. Unfortunately the only kneepads he had were black and these showed through his light beige tights. To help hide them the costume shop ended up covering the kneepads with a white jersey cotton sleeve.

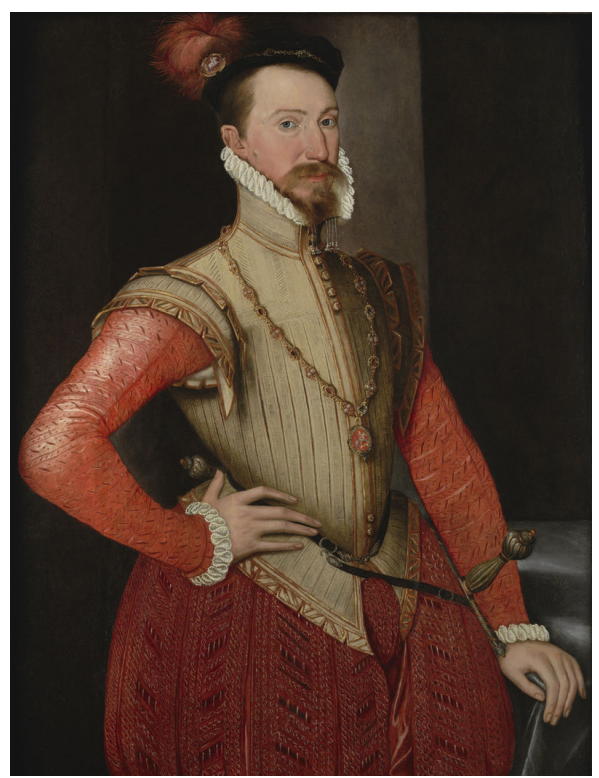

Figure 33: Portrait of Robert Dudley, Earl of Leicester.

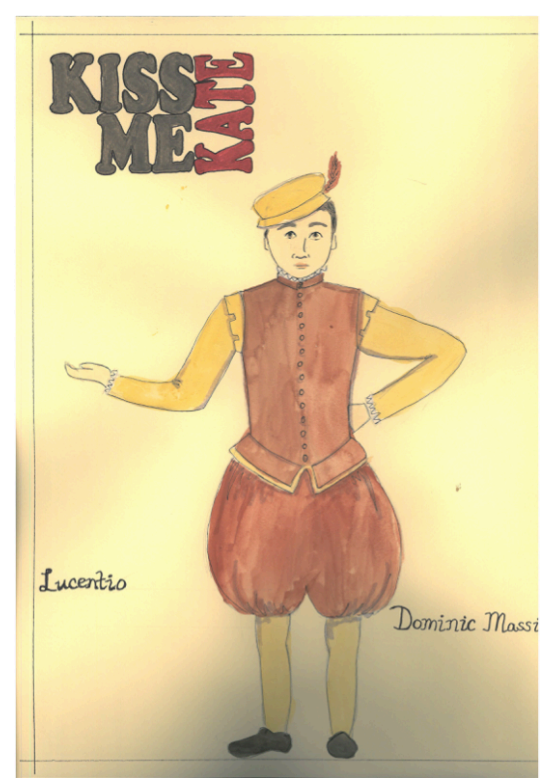

Figure 34: Final Rendering of Lucentio's Costume.

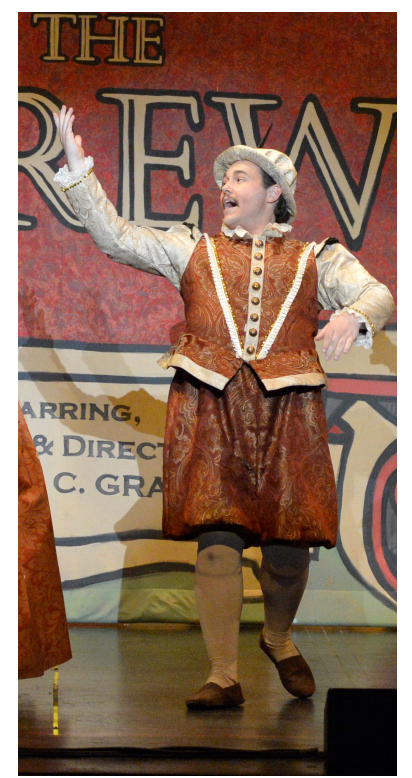

Figure 35: Lucentio’s Costume. 
Gangsters:

To costume the gangsters I wanted to capture the stereotypical look of gangsters in the 1930's and 40's. To do this I costumed them in double breasted chalk stripe suits and gave each of them red lapel carnations, red ties, and black fedoras. The First Man had black and white wing tip shoes and the Second Man had black shoes with white spats. These shoe looks were important, as I wanted them to be visible below the legs of the donkey pants at the end of the show when the gangsters steal the donkey costume to continue participating in the show-within-the-show. While these roles are traditionally played by men but due to an abundance of women in our department, two women were cast in these roles. After a discussion with Professor Britton we decided to keep the characters as men and dress the women as men. To do this we wigged them with short styled wigs and I gave the First Man a ventilated moustache. I had both of the women wear sports bras to compress and reduce their chest size and gave them baggy dress shirts.

Additionally, I taught them to contour their faces with makeup to bring out a masculine facial shape.

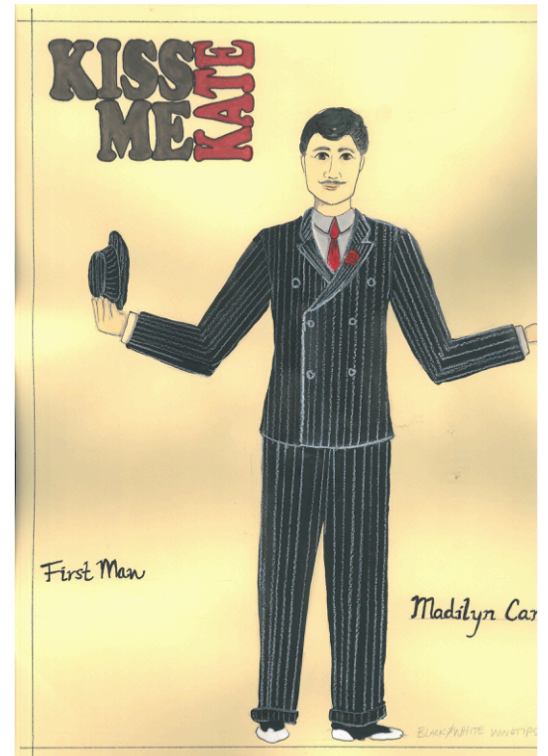

Figure 36: Final Rendering of First Man's Costume.

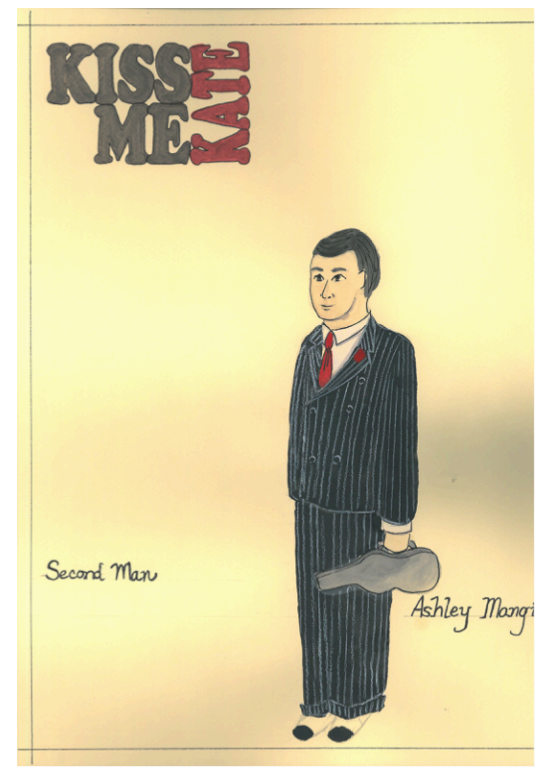

Figure 37: Final Rendering of Second Man's Costume.

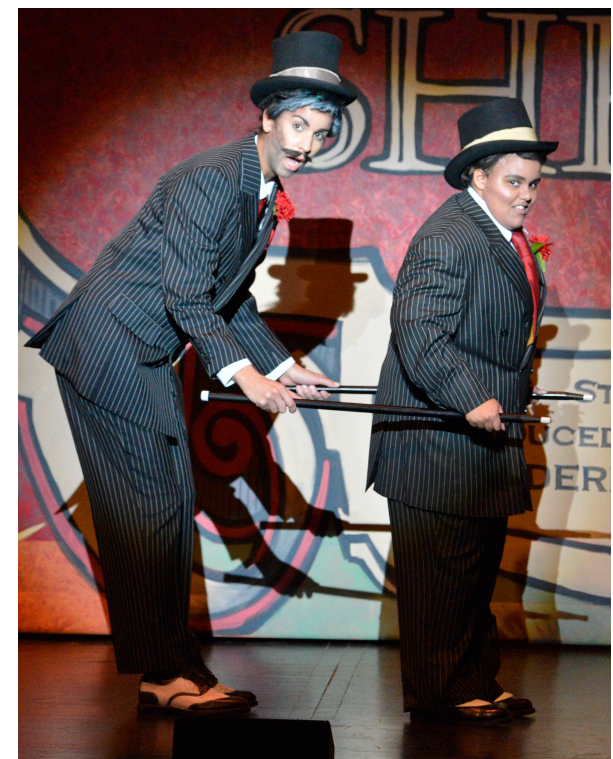

Figure 38: First Man and Second Man's Costumes. 
Hortensio and Gremio:

Hortensio and Gremio have such a small role in Kiss Me Kate for being such an important part of the The Taming of the Shrew story. Luckily from having previously designed The Taming of the Shrew for the University of Wisconsin- Stevens Point's Department of Theatre and Dance, I had a solid knowledge of these characters and their back-stories. Both are from moderately wealthy families and are seeking Bianca's hand in marriage. In Kiss Me Kate they have a large dance number, "Tom, Dick, or Harry", during which they "dance battle" with Lucentio for Bianca's hand with Lucentio coming out of the number the winner. Because of this their costumes had to be build with lots of big dance movement in mind. Both pairs of breeches were built to accommodate large high kicks and both doublets had gussets inserted in the underarm seams. I picked two distinct stripe patterns for them to allow them to stand out from the general ensemble while still allowing Lucentio to stand out from them during their group number.

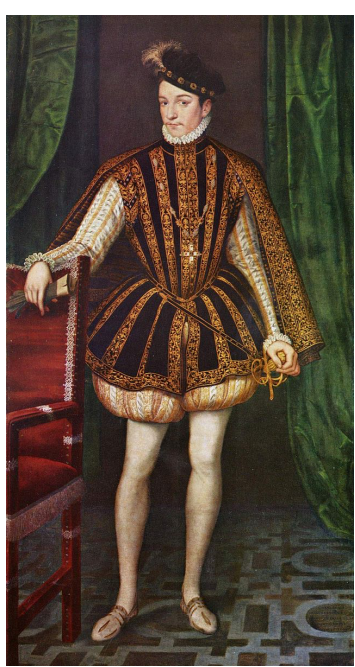

Figure 39: Portrait of Charles IX as an adult.

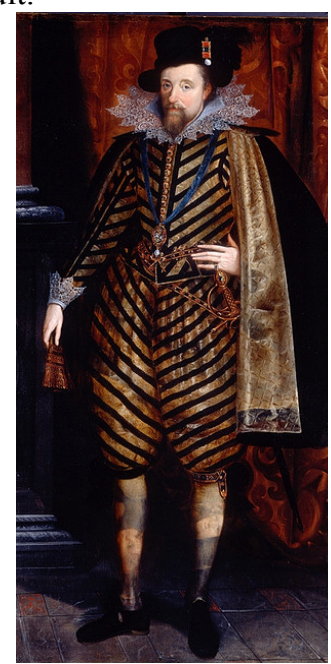

Figure 42: Portrait of James VI of Scotland, I of England and Ireland.

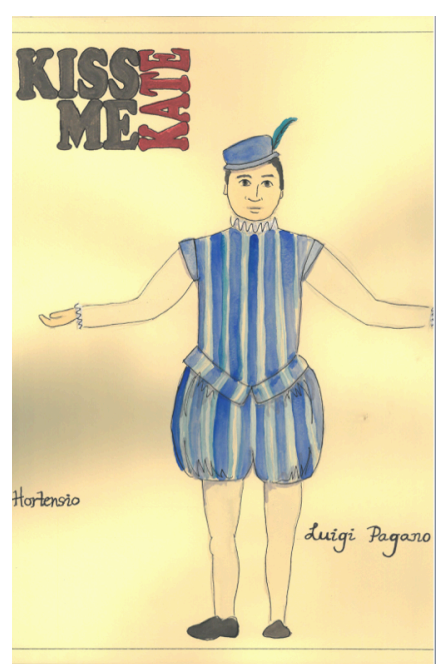

Figure 40: Final Rendering of Hortensio's Costume.

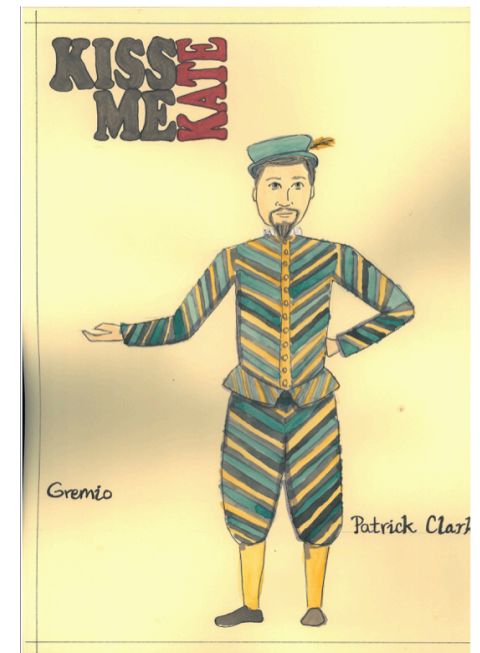

Figure 43: Final Rendering of Gremio's Costume.

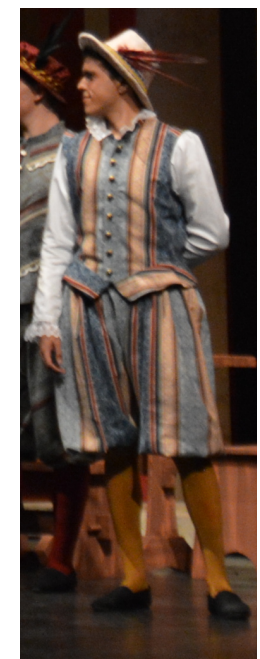

Figure 41: Hortensio’s Costume.

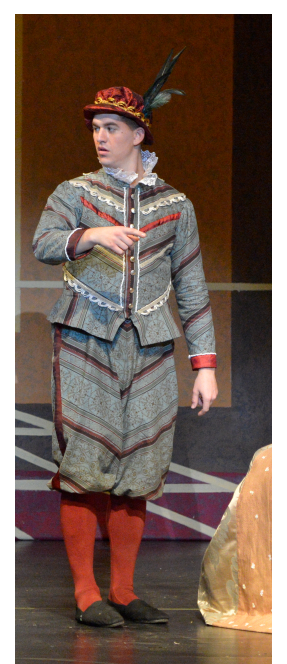

Figure 44: Gremio’s Costume. 


\section{Baptista:}

As the show-within-the-show's patriarch and a wealthy land-owning man it was my goal to make Baptista appear as one of the wealthiest men onstage. To do this I chose rich looking fabrics and lots of gold trim. He also was one of the few characters which had a cape. The actor portraying Baptista had a thin build which necessitated the need for body padding to give him a more portly figure. This actor portrayed Baptista as a doddering elderly man, who was very forgetful allowing us to add some fun pieces in the final styling of his costume. For example, because the actor also doubled as a 1940's ensemble character I gave him glasses that he would "forget" to take off in his change so that when onstage as Baptista he would "realize" that he had "forgotten to take the glasses off and have to hide them in his costume.

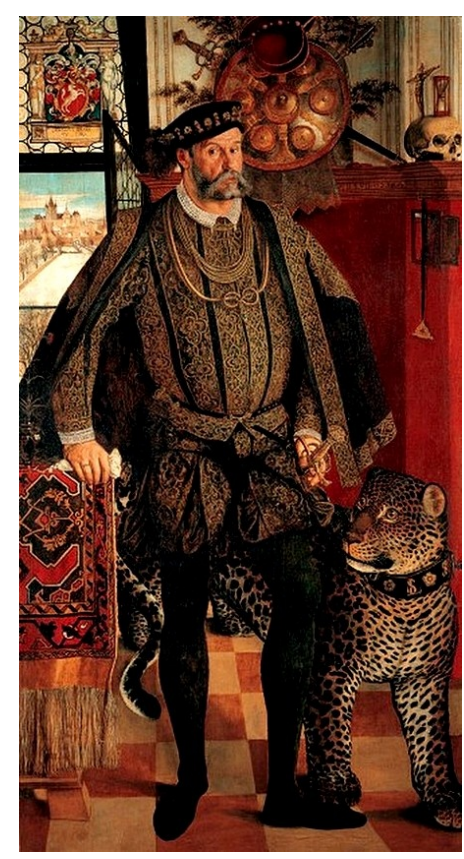

Figure 45: Portrait of Ladislaus von Fraunberg, Count of Haag.

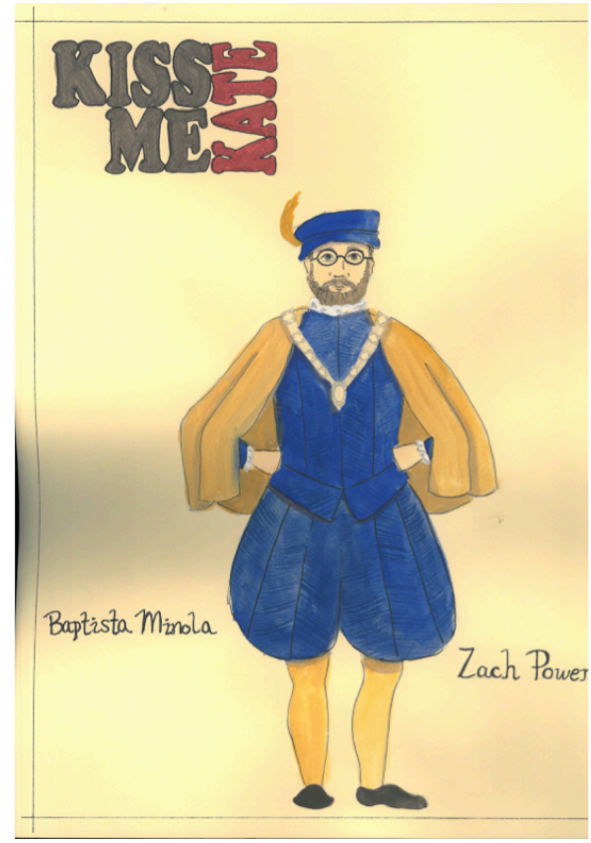

Figure 46: Final Rendering of Baptista's Costume.

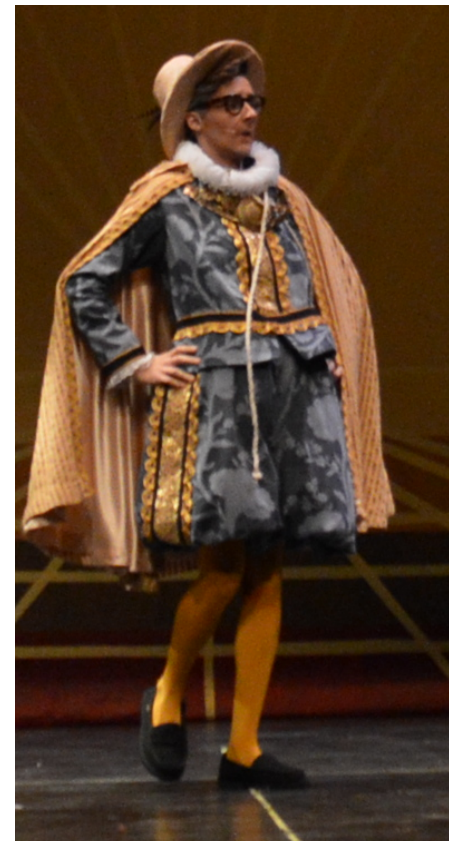

Figure 47: Baptista’s Costume. 
General Harrison Howell:

General Harrison Howell was an interesting character to costume; as he is talked about throughout the show yet is only seen for a short time. Because he is based on General Douglas MacArthur who was an infamous military official I wanted to do my best to make him larger than life. I researched military uniforms of the time because I wanted to base my costume for him on reality, but then take it over the top. Initially I was stuck with this idea, but after talking with Professor McClung she suggested that I should give him a trench coat. This bulked up his shoulders and gave him a larger appearance on stage.

Additionally, as he moved around the draped coat (simulating a cape) would flow after him giving him a larger presence.

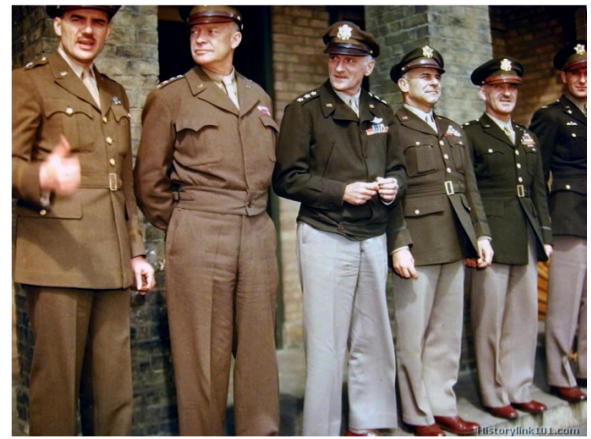

Figure 48: General Anton, General Eisenhower, General Spaatz, General Doolittle, Major General Blakeslee.

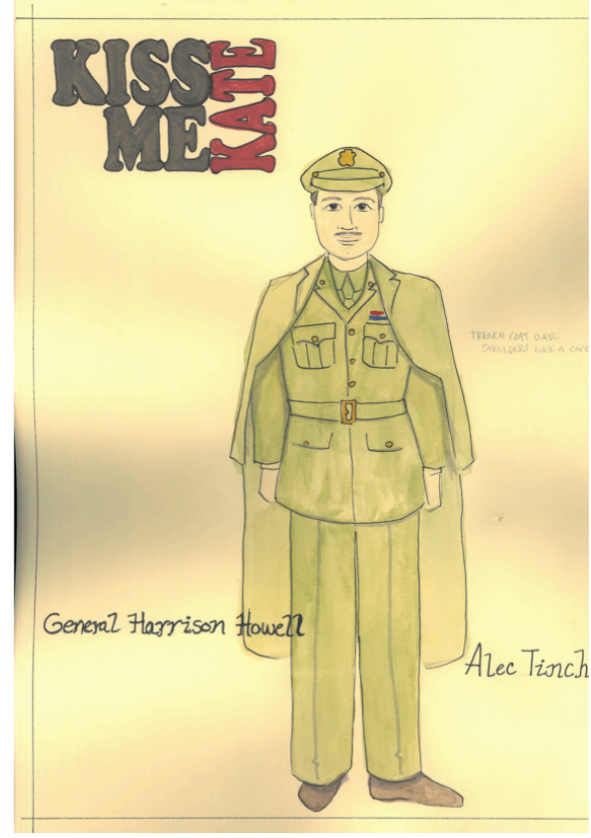

Figure 49: Final Rendering for General Harrison Howell.

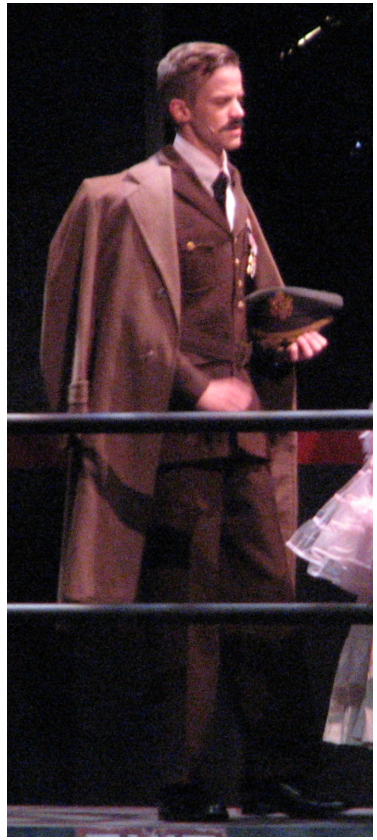

Figure 50: General Harrison Howell's Costume. 
Ma (Pops):

The character of Pops is written in the script as a male role, however as with the two gangsters in our production the roles were cast as a woman. After talking with Professor Britton, however, we decided that we would turn this role into a female role, calling her Ma instead. My inspiration for this character was Rosie the Riveter. I felt that Ma was a strong, smart woman who would not put up with any shenanigans backstage. To portray this in her costume I gave her overalls and a man's button up shirt. She wore work boots and had her hair tied up with a bandana. Additionally, the actor who plays Pops doubles as the Padua Priest during the wedding scenes. In my discussion with Professor Britton we agreed that the Padua Priest character should be kept as male. He would stage the scene to seem that the "actor" who was cast in the Padua Priest role didn't show up to the show and Ma had to step in to play the role at the last minute. This decision gave me an interesting spin to an otherwise small character that allowed me to make some creative choices with it. For instance, I had the cassock the Padua Priest wears hemmed slightly shorter so that we could see Ma's boots and red socks underneath.

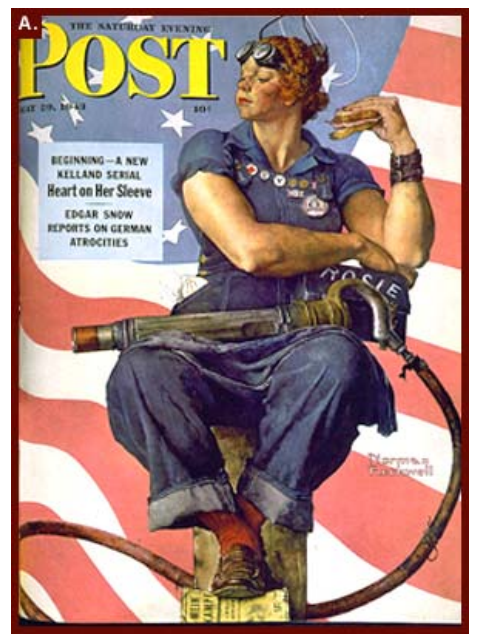

Figure 51: Norman Rockwell's Lithograph of Rosie the Riveter.

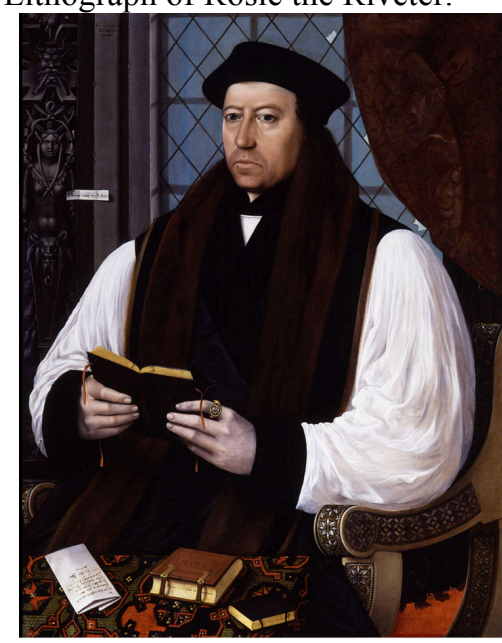

Figure 54: Portrait of Thomas Cranmer, Henry VIII's Archbishop of Canterbury.

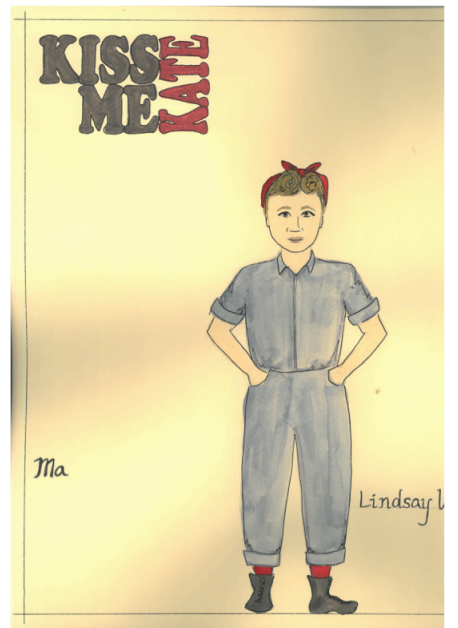

Figure 52: Final Rendering for Ma.

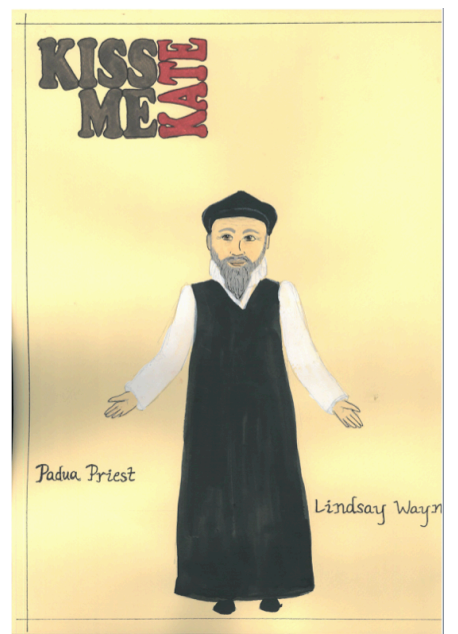

Figure 55: Final Rendering for Padua Priest.

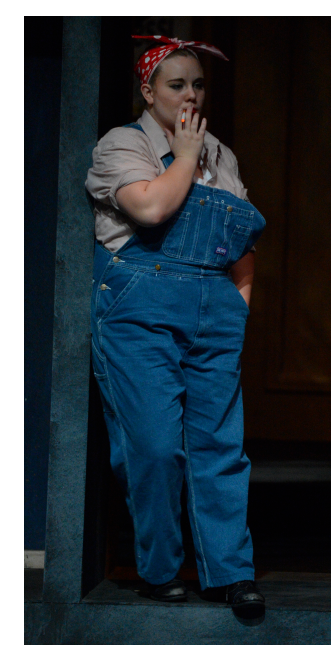

Figure 53: Ma's Costume.

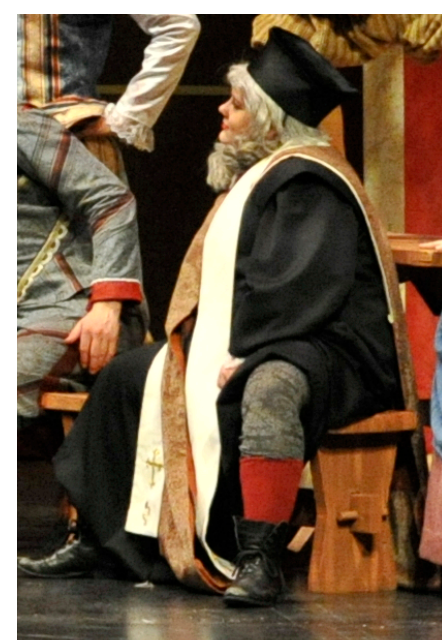

Figure 56: Padua Priest's Costume. 
Other Gender Shifted Roles:

To create more roles for women in the show Professor Britton and I decided to shift the gender of some of the smaller roles as well. This created female roles for a few of the many talented actresses in our department.

Paul:

Paul is Fred Graham's dresser. To shift this role we renamed her Paulette. Professor Britton and I discussed that she would be very flirtatious with Fred but also loyal to Lilli and her dresser Hattie. I dressed Paulette in a slinky circular skirt and a sleeveless button up blouse.

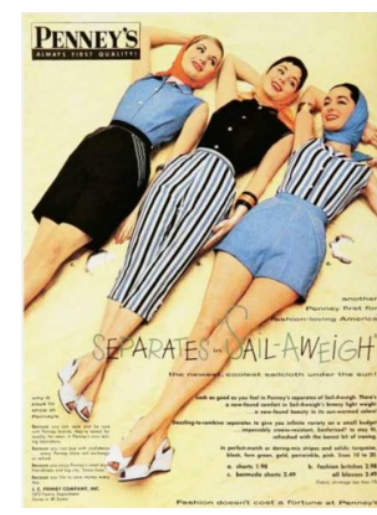

Figure 57: J.C. Penney's Ad.

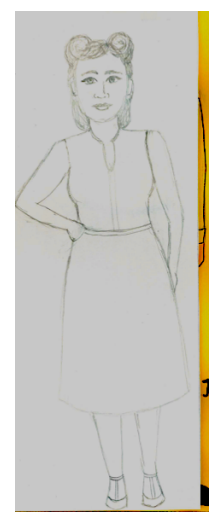

Figure 58: Sketch of Paulette's Costume.

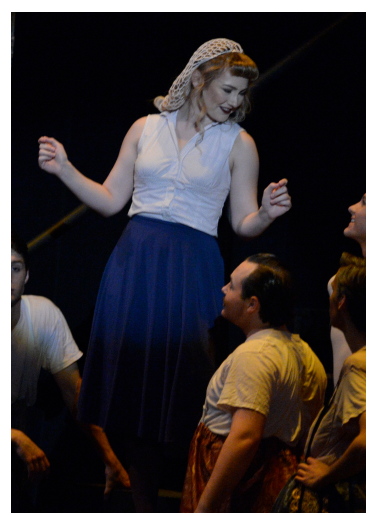

Figure 59: Paulette singing during "Too Darn Hot."

Ralph:

Ralph is the stage manager of the show-within-the-show. To shift this to a female role we renamed her Ralphie. Professor Britton and I discussed that she would be madly in love with Fred and absolutely star struck by him. She spends the whole show trying to ensure that everything is perfect for him, even stepping in to one of the chorus roles during the end of the show-within-the-show to try to replace Lilli when she leaves. To reflect this in her costumes I gave her a very "put together" look, she had a gray aline skirt, a white button up blouse, and a tailored, buttoned vest.

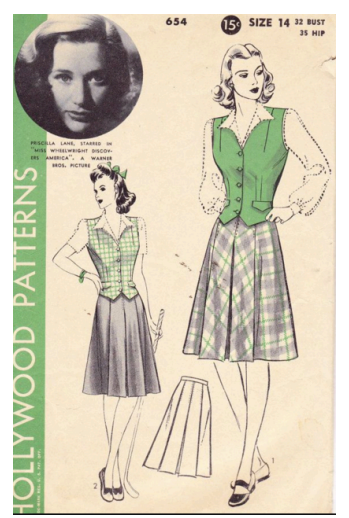

Figure 60: 1940's Clothing Pattern.

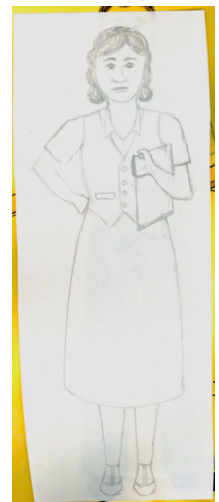

Figure 61: Sketch of Ralphie's Costume.

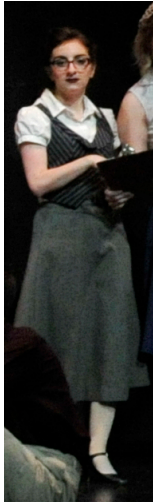

Figure 62 : Raphie's Costume. 
Dance Captain:

The Dance Captain heads up the dance numbers in the show-within-the-show. He also leads the dancing during "Too Darn Hot." For this show we cast this role as a woman. The Dance Captain wore a dance skirt with a sleeveless blouse, and during "Too Darn Hot" she changed into brown shorts with the same blouse.

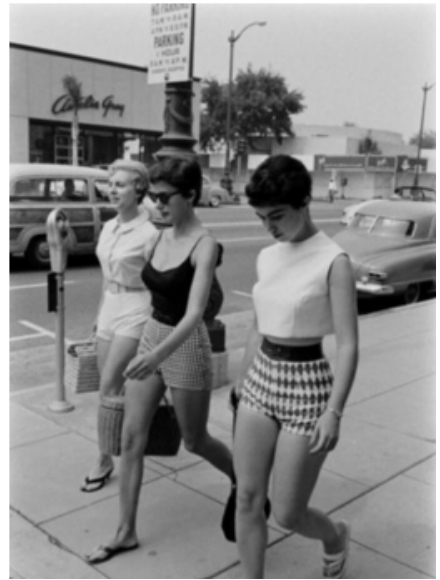

Figure 63: Women in high waist shorts.

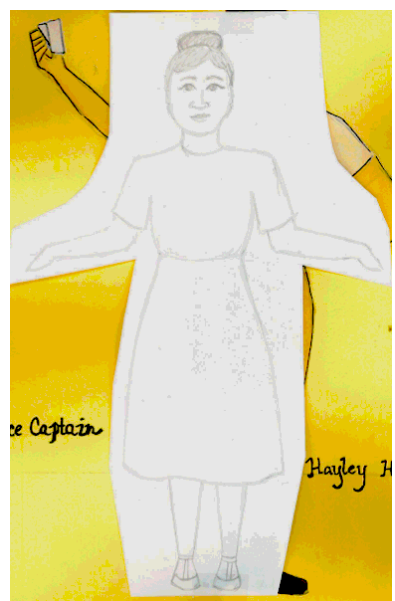

Figure 64: Sketch of Dance Captain's Costume.

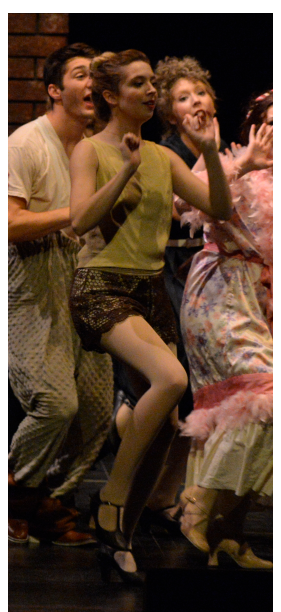

Figure 65: Dance Captain dancing during "Too Darn Hot. 


\section{Ensemble:}

\section{0's:}

Creating the design for the 1940's ensemble was fairly easy. Professor Britton was adamant on every ensemble character having a purpose or job to do that would provide the actor or actress with realistic motivations. Therefore, all the ensemble members were assigned roles such as crew member, wardrobe woman, dancer, etc. I then had to costume these characters for whatever stage work they would be doing. The wardrobe women were in dresses or skirts and blouses with aprons, the stage crew had utility clothing such as suspenders and caps, the dancers were in shorter skirts or "hot-pants" so that they could move through the choreography and show their legs. These subtle choices led to interesting ensemble costumes that went beyond the basic "cookie-cutter" look ensembles can sometimes have.

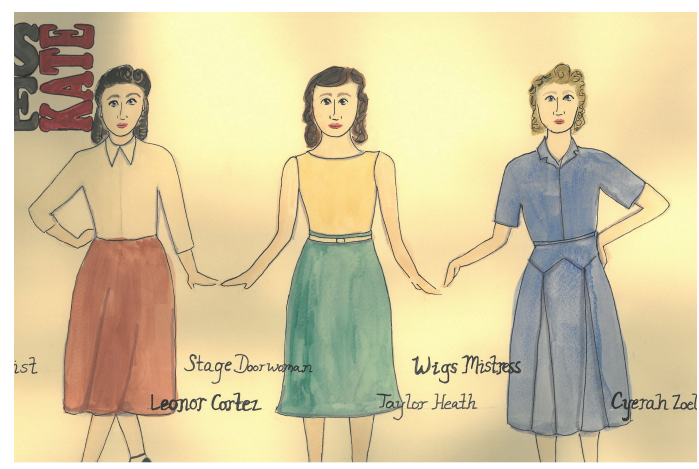

Figure 66: Plate One of Final Renderings for Ensemble Women.

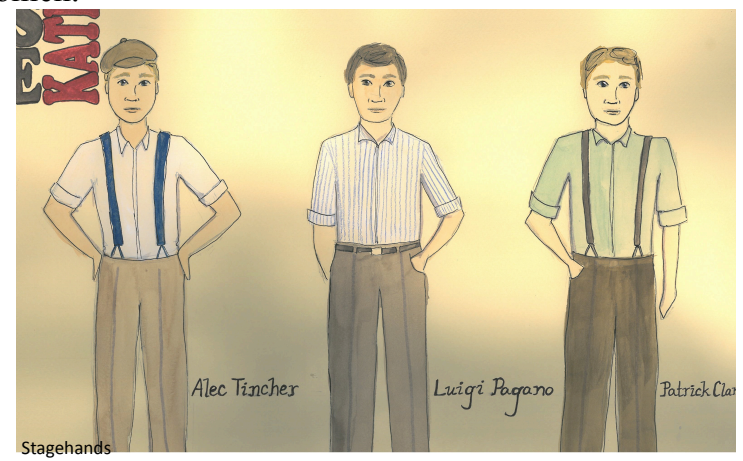

Figure 68: Plate One of Final Renderings for Ensemble Men.

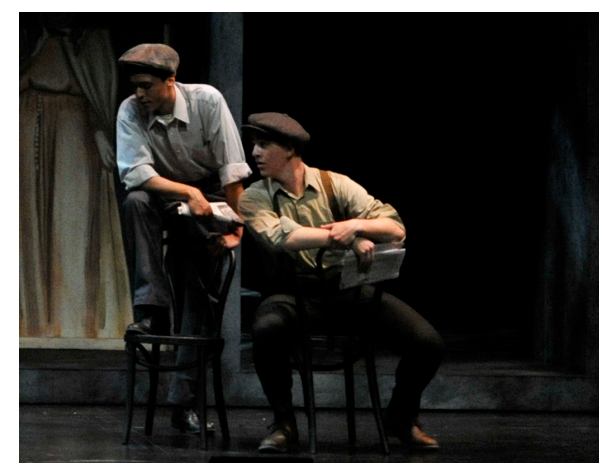

Figure 70: Two of the Stagehands.

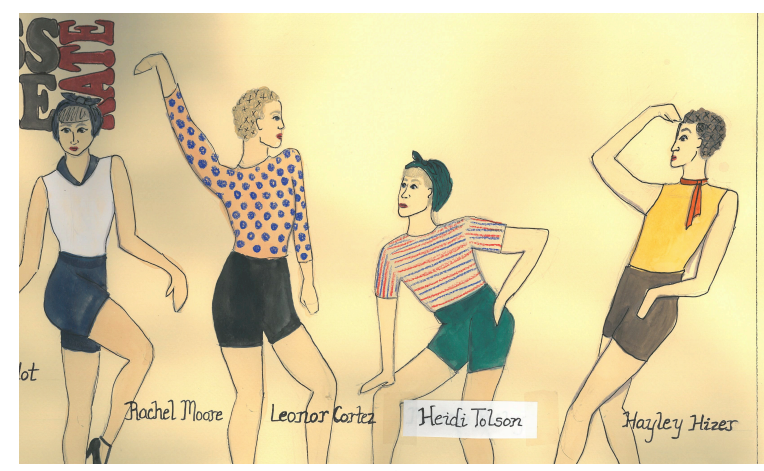

Figure: 67: Plate Two of Final Renderings for Ensemble Women.

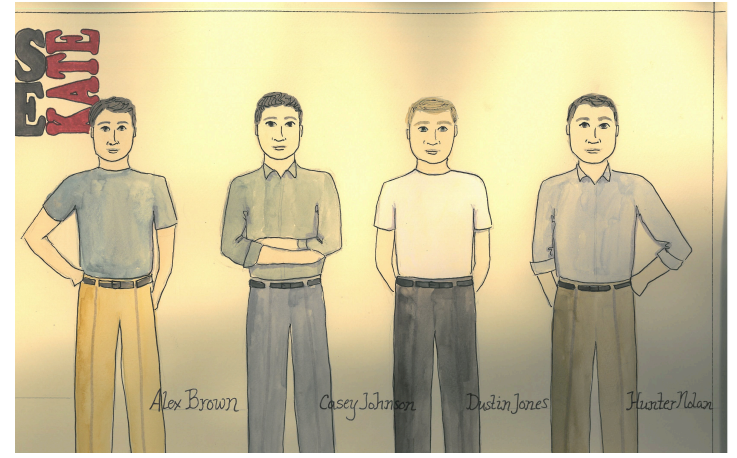

Figure 69: Plate Two of Final Renderings for Ensemble Men.

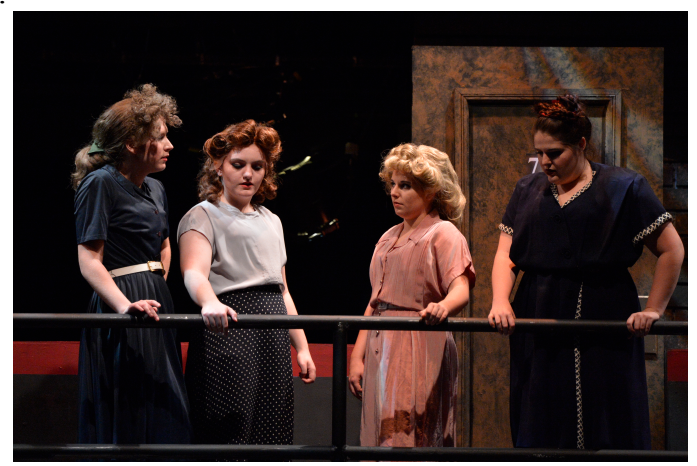

Figure 71: Four of the Ensemble Women. 
Elizabethan:

While researching for the Elizabethan ensemble I found a series of paintings of market scenes by Joachim Beuckelaer, these paintings were my primary inspiration for the costumes of the Elizabethan ensemble. I enjoyed Beuckelaer's use of an earthy muted color palette as well as layers of clothing.

Because the majority of the ensemble's costumes were borrowed I had to alter my intended color palette slightly to include purples and a wider array of shades of blue, brown, and green. However, I feel that I was able to put forth a series of ensemble looks that were unified yet still interesting.

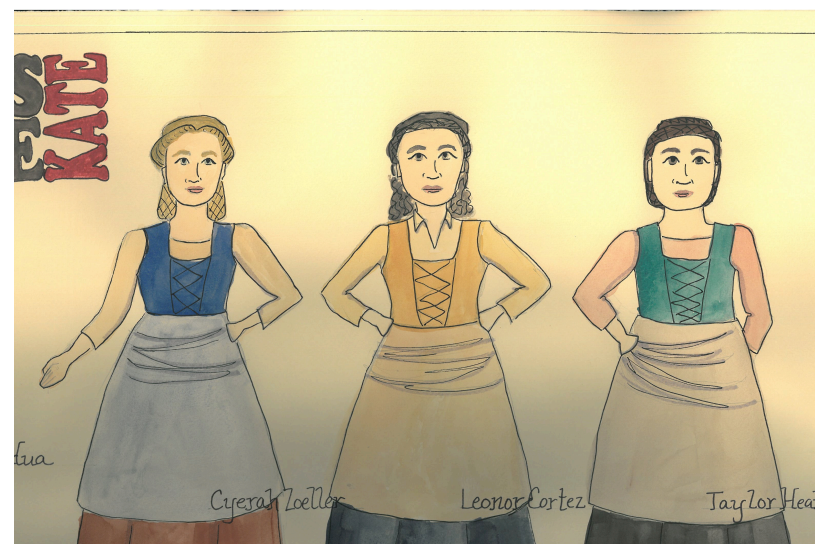

Figure 72: Plate One of Final Renderings for Ensemble Women.

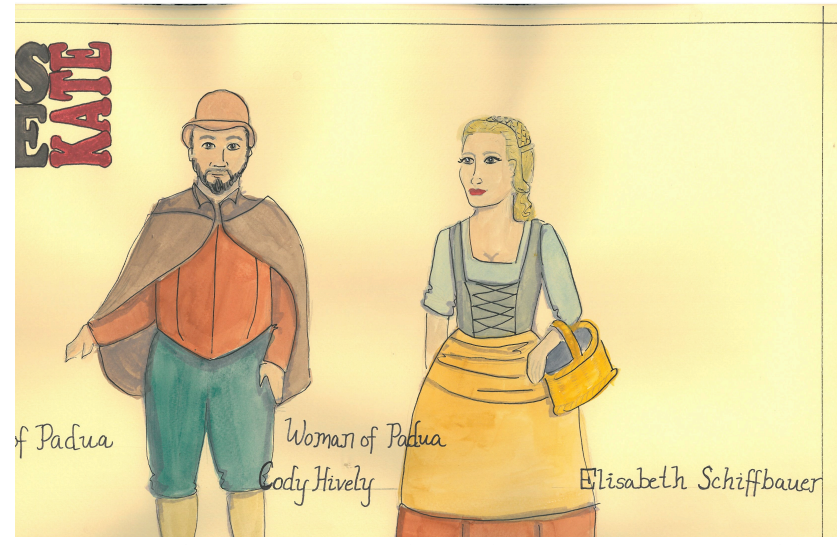

Figure 74: Plate One of Final Renderings for an Ensemble Man and Woman.

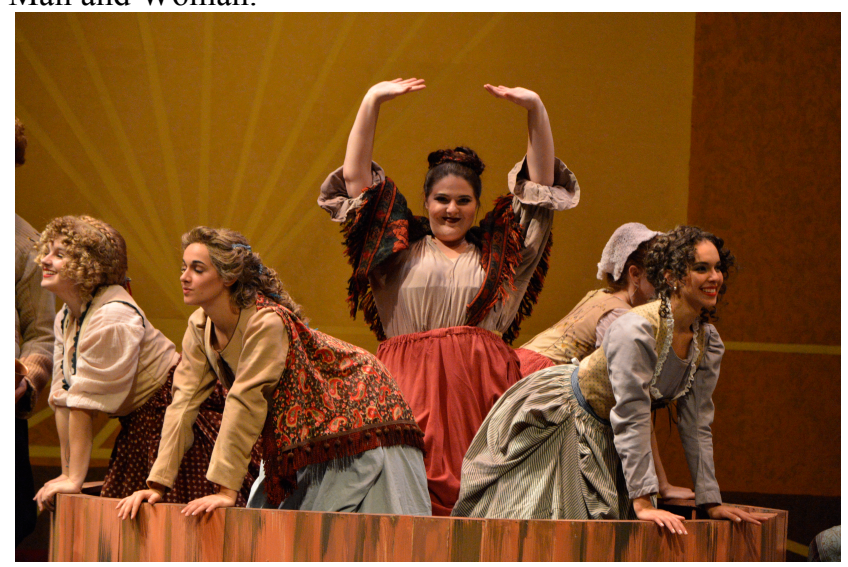

Figure 76: Ensemble Women during Cantiamo d'Amore.

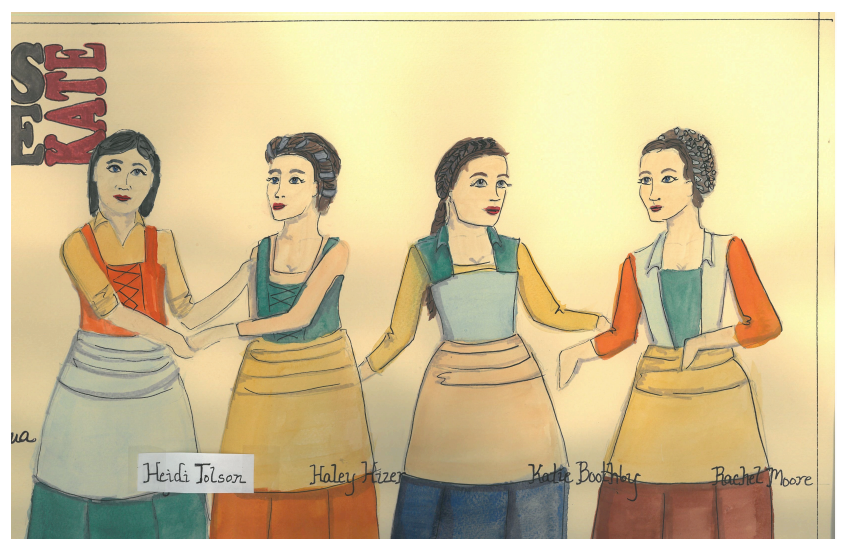

Figure 73: Plate Two of Final Renderings for Ensemble Women.

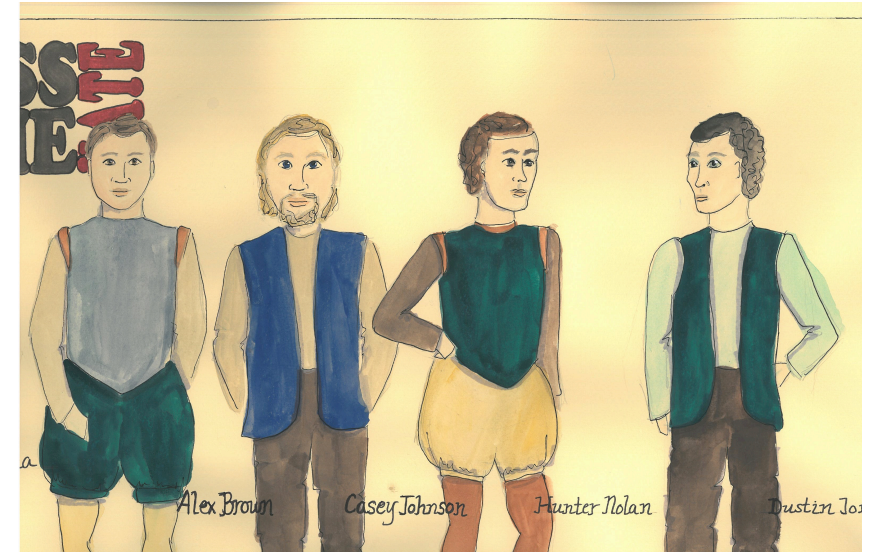

Figure 75: Plate Two of Final Renderings for Ensemble Men.

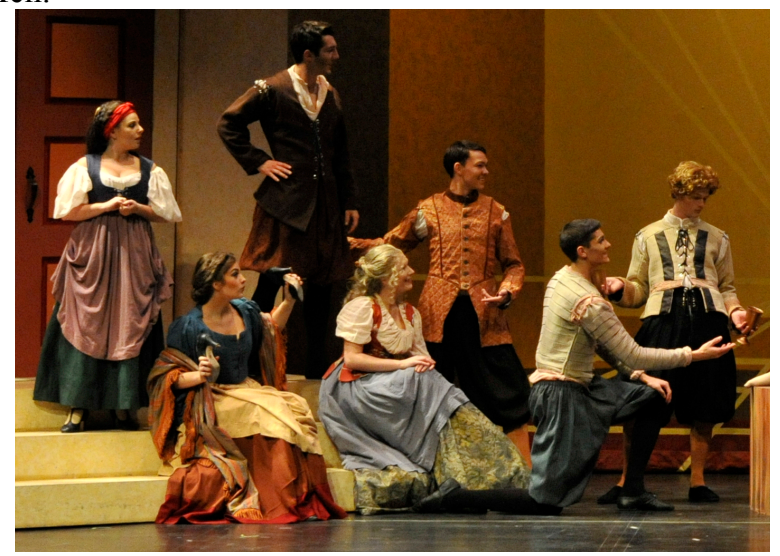

Figure 77: Ensemble Men and Women during Cantiamo d'Amore. 


\section{Organization}

Designing and executing a show of this magnitude that included two distinctly different time periods was quite the undertaking. I had never designed for a musical of this size so I endeavored to stay as organized as possible to keep the production on track.

- Character Breakdown: Because of the size of the show and the number of changes back and forth from the onstage area to the backstage area I created a thorough character breakdown divided into scenes and musical numbers listing each character including ensemble members. I then went through and noted my initial ideas on costume variations in each scene/musical number. After the show was cast I was able to make changes to this breakdown and provided a print out to my stage manager to take to rehearsal. This "costume plot" helped the director and actors by reminding them what they would be wearing throughout the show (See Appendix C). Additionally, I was able to provide my wardrobe crew with a costume plot based on my full plot to help them track each actor. (See Appendix D)

- Piece List: Once I had designed and rendered the show I went through and created a detailed piece list. This list detailed every costume piece attributed to each actor from hats to shoes and everything in between. Using this list I was able to figure out what I needed to pull, borrow, rent, purchase, or build. I continued to refer back to this list, changing and adding to it as the build process progressed. (See Appendix E)

- Initial Budget and Shopping/Rental Estimations: As a part of the initial design process I was required to go through and budget what would be spent on fabric, rentals, purchased items, etc. months before casting and before I knew what I could use from stock. This resulted in an initial estimate almost $\$ 700$ over my budget of $\$ 5000$. The budgeting process showed me that I needed to cut spending and I did this through borrowing costumes instead of renting as well as cutting back on yardage and shopping for lower priced fabric for the build process. (See Appendix F \& G)

- Pulling, Borrowing and Renting: Due to working on a 1940s show the previous fall I had a pretty good knowledge of WVU's stock of 1940s dresses, skirts, and men's suits. This allowed me focus on finding the costume pieces that would work for the Elizabethan era costumes. These efforts definitely paid off as I found much more in stock than I had expected. However, this was not 
enough to clothe my entire cast so I turned to Fairmont State University and The University of Wisconsin-Stevens Point for costume loans. I traveled to Fairmont State University and found many women's vests as well as skirts, blouses, and some men's breeches. When I was in Wisconsin in May I went to UWSP's stock and took pictures and measurements of costume pieces that I thought I might need in the fall. Once I got actor sizes later that September I quickly sent off an email to the shop manager, Wendy Dolan, requesting the specific pieces needed. There were a few items needed (specifically a set of three doublets and breeches for Petruchio's servants as well as a cassock and hat for a Elizabethan era priest) that I was not able to find from our stock, FSU's stock, or UWSP's stock, so I turned to Oregon Shakespeare Festival for rentals. Luckily over the summer I worked in a shop that had rented and borrowed costumes and I used a few of the organizational tricks I learned there. One of these tricks was to tag each rental item being used in the show with a small, colored square of fabric to denote which source they came from. I assigned each source a different color and posted a sign in the costume shop with these color assignments. This allowed me to keep track of which pieces came from each organization and ensure that they were returned back to the correct place.

- Costume Shop Work Flow: While I was rendering over the summer months, I also created a calendar for myself of important dates and goals for completion of various tasks (See Appendix H). This calendar I then sent to Director of Costumes McClung who used my dates as a basis for the show work calendar that she prepares every semester. Between these two calendars I did my best to stay on track so that I was always prepared and the shop staff were never waiting on me to continue working on build projects. Additionally I printed off a piece list for each actor that I used for notes during fittings. These notes included alterations, trims, or other things that needed to be done to the various costume pieces. After fittings I would type these notes up and would print out charts so that the whole costume shop could see what needed to be done to each costume piece and we could cross things off when they were finished. 


\section{Section 2: Process}

\section{Build Process}

For this production I was told that the costume shop could build 9 full costumes. After designing the show I decided the following costumes would be built:

- Lilli Vanessi: Blue Satin Dress

- Katherine: Coral Elizabethan Gown

- Lois Lane: Pink Dress

- Bianca: Buttery-Gold Elizabethan Gown

- Petruchio: Gold Elizabethan Doublet, Pumpkin Breeches, Ruff, and Hat

- Lucentio: Red and Gold Elizabethan Doublet, Pumpkin Breeches, and Hat

- Baptista: Blue Elizabethan Doublet, Pumpkin Breeches, and Hat

- Gremio: Green Stripe Elizabethan Doublet, Breeches, and Hat

- Hortensio: Blue Stripe Elizabethan Doublet, Pumpkin Breeches, and Hat

The costume shop decided to split the builds between the shop staff. This way each staff member could ensure that the project was run through the labs and be ready on time. I personally took over the build of Lilli's blue satin dress, Graduate student Lauren Brennan supervised the build of Petruchio and Hortensio's costumes, Graduate student Cody Lorich supervised the build of Lucentio and Gremio's costumes, Costume Shop Manager Sharon Goeres supervised the build of Baptista's costume as well as the men's hats, and Costume Shop Cutter/Draper Professor Washington Brown took on Katherine, Lois, and Bianca's costumes. In order to keep the shop on schedule, the Costume Director and Costume Shop Manager created a build schedule that all shop employees endeavored to maintain. Unfortunately due to a family emergency, Professor Washington-Brown fell behind on her projects, which caused me to worry if the garments would be wearable in time for first dress. Luckily, she was able to have a student assist her with finishing her builds and they were wearable by first dress. However, some of the finishing had to be completed by the other shop staff after first dress.

The shop was able to complete many alterations on costumes pulled from stock in addition to the nine built items. After a busy week of pulling from our stock and the trip to Fairmont State University, I had almost the entire ensemble costumed. The thirty ensemble costumes were then fit on actors over the course of about two weeks. After fittings the shop staff assisted in prepping the alterations for our lab students to sew. Through working on other shows over the past two years in our costume shop, I saw how it incredibly important to keep up on "prepping” (preparing garments for alterations after fittings by 
pinning or marking alterations) so that the labs can do the bulk of the alterations and they don't end up falling on the shoulders of the shop staff. This was something I strived to do throughout the Kiss Me Kate build period.

For this show I was lucky in that Professor McClung was offering a wig making class. The class was able to build and style all the wigs and hairpieces for my show. This allowed me to ask for more wigs to be used in this show than we had traditionally put in shows in the past. To communicate the wig designs I created a PowerPoint with a page for each wig supported by research (See Appendix J). I then met with Professor McClung and the wig class students (Graduate Students Cody Lorich and Lauren Brennan) to discuss the wigs. They then split the wig list between the three of them and got to work putting together a beautiful set of wigs. It was decided because of the large amount of wigs the costume run crew would need an additional crew member to handle the reblocking and maintenance of the wigs during the run of the show. This crewmember was essential to ensuring that the wigs looked their best throughout the performances.

For the publicity photos Professor Britton and I decided to have Lilli Vanessi wear her 1940s dress and Fred Graham wear his Petruchio costume. We hoped to shoot these photos using the actual show costumes instead of pulled pieces from stock. While it seemed like a task that could be accomplished, due to preexisting issues in the shop I unintentionally overwhelmed Graduate Student Lauren Brennan who was assigned to oversee building Petruchio's costume. Lauren did her best to complete the doublet in time, however to keep from rushing the final details Professor McClung and I decided that we would use only the pumpkin hose that she had finished for the actor and I would pull a period style shirt and vest for the publicity photos. The final look was perfect for the shoot even it was not the first choice.

Rehearsal shoes and rehearsal wear always seems to be an issue in our costume shop because of how rigorous the rehearsal process can be and the shop's desire to keep our stock in a good condition. However, from the start of the design process I discussed with Professor Bryce Britton and Professor General McArthur Hambrick (the Director and Choreographer) that the actors would be providing their own character shoes as well as any of the dance shoes needed. This way the actresses and actors would be prepared for all rehearsals and for any future productions in which they might be involved. I did provide corsets and petticoats for the actresses to wear at rehearsals so that they would become accustomed to moving in them. This provided a smoother transition from rehearsal wear into dress rehearsals. 


\section{Dress Rehearsals}

For the size of the show the dress rehearsal process and production run went very well. I did my best to facilitate this by working with shop staff and stage management to ensure the cast and wardrobe crew were well prepared.

On the Saturday before the first dress rehearsal we ran a one-hour wig and hair training. Because of how chaotic these sessions usually are and because I had a handful of actors who needed to get their microphones before the sitzprobe started, I coordinated with design undergraduate Ricky Moats, the Sound Designer for the show, to ensure that I got actors to him in time to get their microphones. To facilitate this the Graduate Wardrobe Supervisor, Cody Lorich, and I decided to split the actors into two groups; each had 30 minutes to work with their dresser to get their wig on and off and secured correctly. The split-group sessions allowed me to have all the actors who needed microphones in the first group and then the second group had the rest. Because of how quickly we needed to run our training session it meant that it was essential for all of the actors to show up to their assigned session with their hair already pin curled. I found a YouTube video online that had a nice description of how to pin curl hair and emailed it to all my wigged actresses a week in advance of the wig training so that they could take time to learn how to pin curl their own hair.

In addition to the wig training session, I had a lot of cast members who had not been through a basic makeup class and did not know how to apply "basic corrective makeup." To help them I offered 3 different sessions in the week leading up to technical rehearsals where I taught them how to apply basic corrective makeup, giving them the opportunity to apply the makeup to their own faces.

On the morning of "first dress" I met with the wardrobe crew to go through all of the costume pieces on the rack; walking them through the pieces involved with each change, telling them how pieces were to be worn, and talking through quick changes. Graduate Wardrobe Supervisor Cody Lorich and I also split the dressers into teams that were assigned to each of the quick-changes (See Appendix K). Once we had completed this talk the crew prepared for the actors to show up for rehearsal.

As the actors arrived the dressers were able to check in with them regarding their specific costume changes, discussing where was the best place to perform the change backstage. Prior to starting the run we gave the wardrobe crew an opportunity to run a few of the more complicated quick changes. This "quickchange rehearsal" gave the wardrobe crew and actors a chance to get familiar with the costume changes outside the framework of the show, and allowed the wardrobe supervisor and myself a chance to target costume pieces that needed to be quick-rigged. 
First dress went rather smoothly for a show its size. I had a reasonable list of notes from the rehearsal. The notes I had included hems, tightening suspender straps, and adding more trim. I also had a few bigger notes that, I as the designer, saw as distracting. Most importantly I had decided that the burgundy vest I had pulled for Petruchio's wedding costume was not extravagant enough. It needed more detail. Luckily WVU had a doublet with faux-leather stripes that fit the actor playing Petruchio. I was able to use it by adding red and gold trim. Additionally, I realized while watching the show that Katherine needed to show up to Petruchio's house at the top of Act II looking disheveled. We already had a separate messy wig for this look, however I needed to add something to her dress to echo the hair. After speaking with Professor McClung we decided to add two snap-on distressed panels to her skirt and one panel to her sleeve using left over fabric from her original costume. This provided the messy, disheveled look without having to find or build another costume.

The Second Dress Rehearsal saw fewer notes than the previous rehearsal. Again I wanted the shop to add more trim and sparkle to the costumes, with a few minor adjustments for fit. I also had the costume shop steam and iron all of the petticoats for the female chorus because they were wrinkled and flat from being used in rehearsals for weeks. This gave all the skirts more volume.

The Third Dress Rehearsal went very smoothly which was a relief as it was our last. I only had notes to again add more sparkles and trim to the costumes. I also had the costume shop stitch white covers over the black kneepads that the actor playing Bill/Lucentio wore under his off-white tights.

Unfortunately backstage in the female dressing room there arose a few issues that had to be addressed. Some of the actresses had been careless while removing their costumes post show and had left a large mess including a microphone pack left on the ground, and open makeup that had been spilled all over certain costumes. The dressers also felt that there was a lack of professionalism on the part of the actresses. I informed Professor Britton and he quickly sent off an email to the cast addressing the incidents and reminding them of dressing room etiquette this included cleaning up any messes that were made while getting ready, ensuring that costumes were hung up after changing out of them, and keeping any music being played to a low volume. The actresses responsible came to apologize to me the next day and the dressers reported a change in attitude towards them.

\section{Run of Show}

The only technical issue for the costume crew was a last minute need for a replacement dress. The original dress started falling apart during a performance. With the exception of this emergency glitch the show was incredibly well received and I as the costume designer was awarded many generous 
compliments. I was even approached with the possibility of my design being used by Opera Theatre Pittsburgh's 2016 Summerfest production of Kiss Me Kate. 
Section 4: Evaluation

\section{Positive Experiences}

The most positive experience I took away from this design was that most of the builds went smoothly through the shop. Because of the diligent notes and paperwork I kept during the design and build period I was able to stay on top of all aspects of the carious projects which kept me from getting overwhelmed this also ensured that the shop had whatever supplies or information they needed to stay on schedule. I had seen previous graduate students become very stressed during their thesis show and learned that organization is one key to staying on schedule. The other positive was having good costume shop support. Costume Shop Manager Gores and the Director of Costuming McClung were instrumental to getting the build through the shop smoothly, and fellow graduate students Cody Lorich and Lauren Brennan were powerhouses of prepping, ensuring that alterations were ready for lab students to work on.

\section{Lessons for the Future}

One of the most important lessons I am taking away from this experience to ensure my voice as a designer is heard, regardless of whether shop personnel such as the draper is brusque and not really willing to collaborate. Because of this dynamic there were many design choices that were ignored and at times I felt that my vision as a designer was not being respected or encouraged. Because I was a graduate student and afraid of backlash from the faculty cutter/draper I felt that I could not be honest with her and could not go back and change things that had been interpreted incorrectly. The biggest obstacle during the construction of the costumes was the lack of interest and flexibility on the part of the cutter/draper. I also gained an appreciation of how important communication can be. The most poignant example of this was with the bodice of Bianca's gown. I had designed the trim to go straight down the front of the bodice however after looking at it in fittings and the way the design had been translated I grew concerned that the trim made the actress look too boxy. It was very wide where it joined the skirt. Again I was intimidated by the faculty cutter/draper who had constructed the bodice and I felt uncomfortable approaching her to ask for the trim to be changed. After seeing the bodice on stage at first dress and talking to Professor Britton, and Professor McClung, we decided that the trim needed to be changed. Because the trim was stitched intrinsically to the pieces during the bodice construction instead of topically after it was put together, I then had to pull the bodice apart. We shifted the trim and the bodice was reassembled. Had I voiced my opinion earlier this would not have been necessary.

Another lesson that I took away from this experience is the importance of receiving feedback from my director. Because the director, Professor Britton, and I are friends I felt that sometimes he wouldn't 
give me the constructive criticism I needed. It made me, push him for feedback or to just "let it go."

While I am thankful that he trusted me as a designer and appreciative of being allowed me to make many design decisions alone, I wish he would have given me his opinion more often, even if it was in agreement. 


\section{$\underline{\text { Appendices }}$}

\section{Appendix A: Research Image Slides}

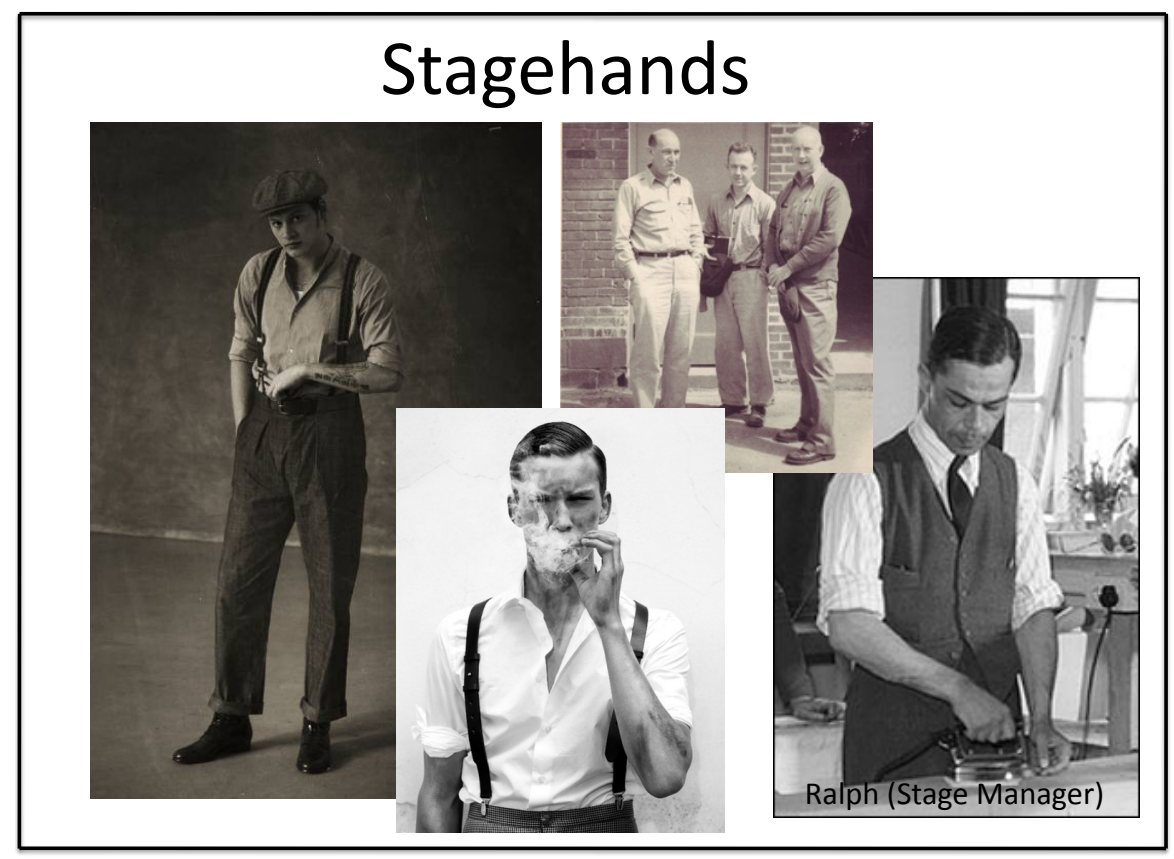

Left Image: Honest, Hardworking Mens Apparel. 2010. Three Over One AW2010 Men's Clothing Collection. Fashion Review Australia. Web.

Top Center Image: Ebert, Roger. My Old Man. N.d. Roger Ebert.com. Web.

Bottom Center Image: Valois, Nicolas. Untitled. N.d. Amp Agency Ltd. Web.

Right Image: Parkinson, Justin. "Steam Iron Gets Makeover for Men." BBC News. BBC, 02 June 2006. Web.

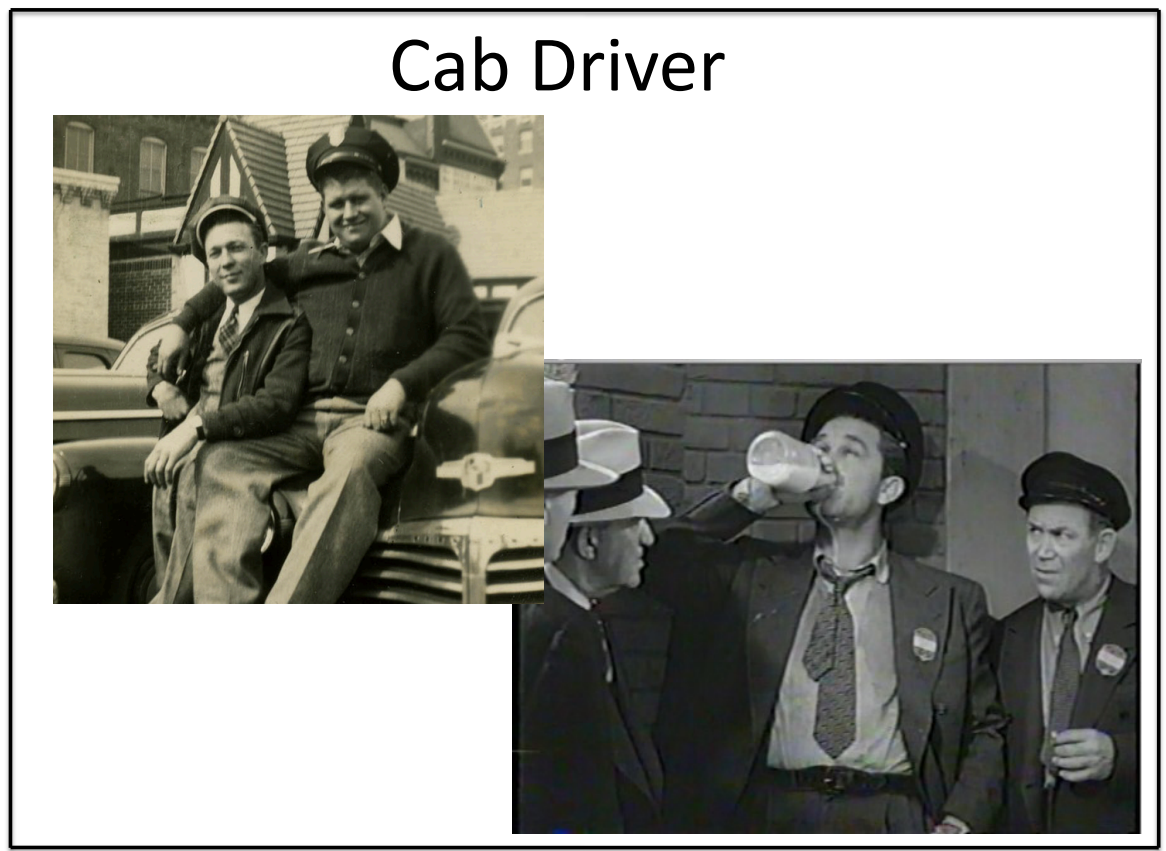

Left Image: Affectionate Taxi Drivers - 1940's. Ipernity. N.d. Web.

Right Image: Mogg, Diarmid. Edgar Dearing in Big City. 1937. The Unsung Joe. Web 


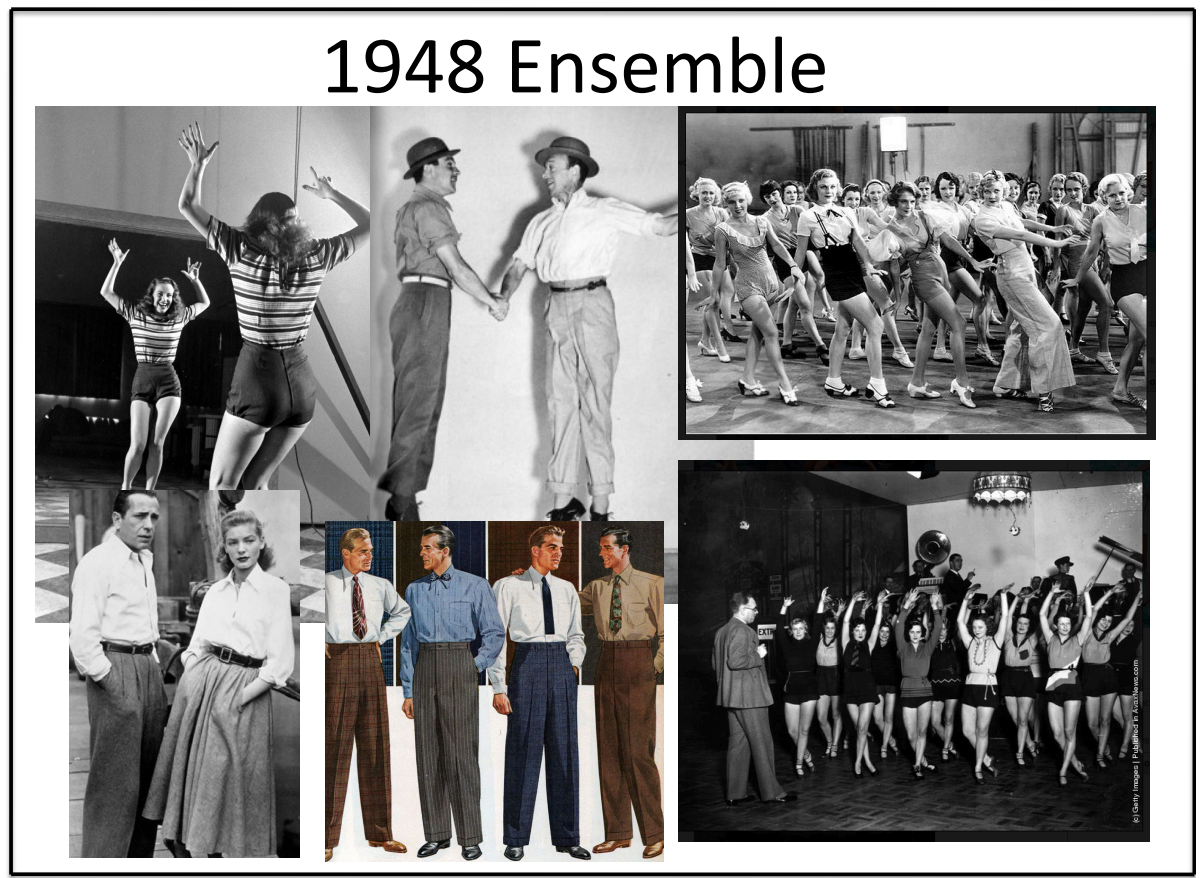

Top Left Image: Unknown. Chorus Girl Rehearsing. 1947. Yeh Yeh Grace. Web.

Top Center Image: Unknown. Gene Kelly and Fred Astaire rehearsing for "Ziegfels Follies." 1946. Classic Cinema Gold. Web.

Top Right Image: Warner Bros. $42^{\text {nd }}$ Street. 1933. IMDB.com. Web.

Bottom Left Image: Unknown. Humphrey Bogart and Lauren Bacall on the set of "Key Largo" directed by John Huson. 1948.

The Red List. Web

Bottom Center Image: Unknown. Men's Dress Trousers Pants Sears Cut. 1944. The Life Nostalgic. Web.

Bottom Right Image: Getty Images. Mr. Andre Charlot rehearses his chorus. $18^{\text {th }}$ November 1929. Vintage Everyday. Web.

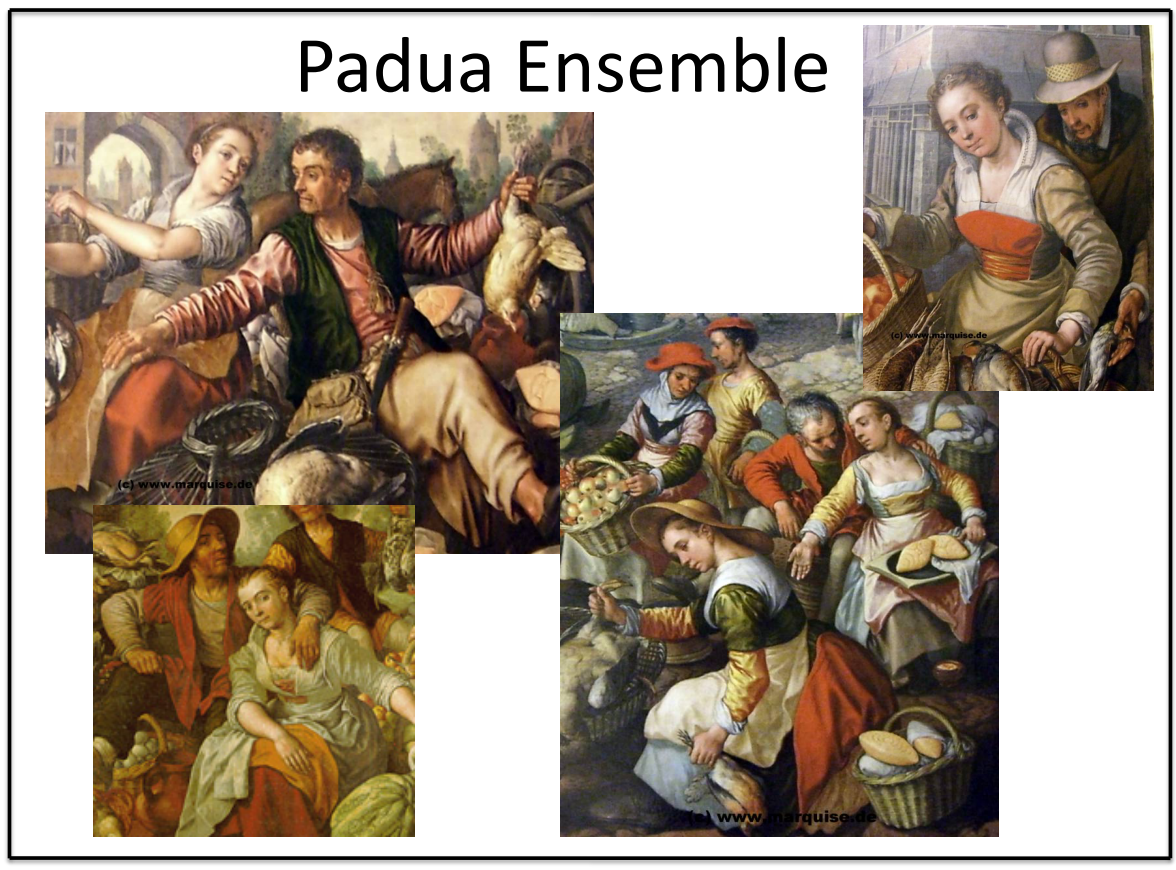

Top Left Image: Beuckelaer, Joachim. Fowl Vendors. 1566-70. Museo di Capodimonte. Web Top Right Image: Beuckelaer, Joachim. Market in Town (detail). 1566. Museo di Capodimonte. Web Bottom Left Image: Beuckelaer, Joachim. Country Market. 1566. Mueso di Capodiomonte. Web.

Bottom Right Image: Beuckelaer, Joachim. Marketplace (detail). 1560-70. Mueso di Capodiomonte. Web 


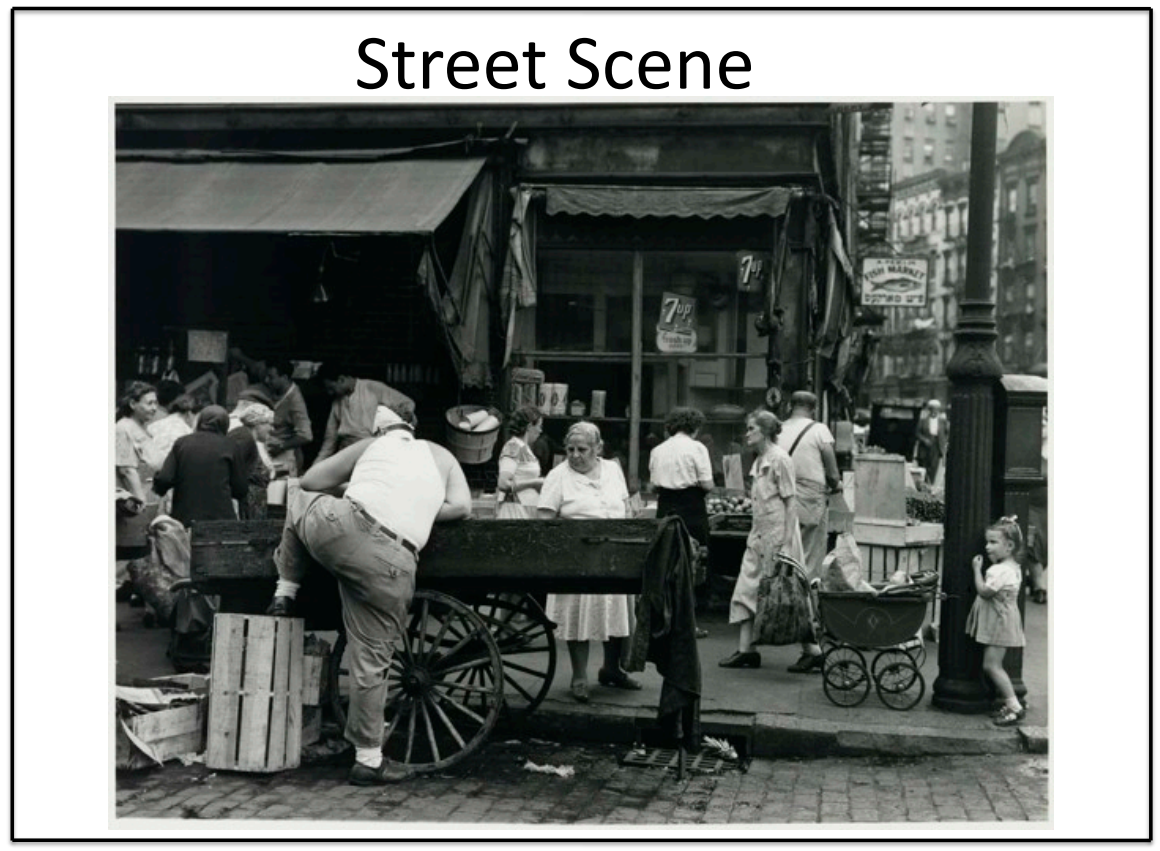

Webb, Todd. Street Market, Suffolk Street, New York. 1946. WilliamLanday.com. Web

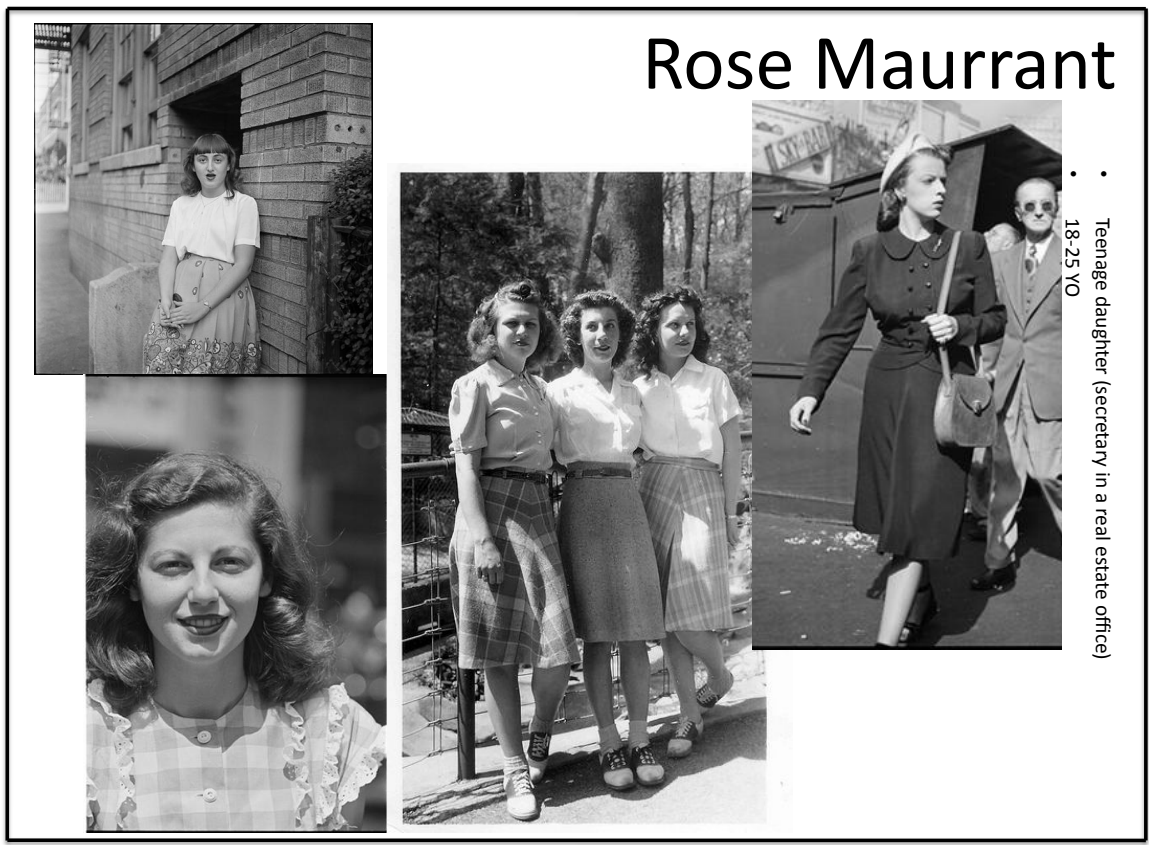

Top Right Image: Kubrick, Stanley. Woman leaning against a building. 1946. Museum of the City of New York. Web Bottom Right Image. Kubrick, Stanley. Portrait of a Woman. 1946. Museum of the City of New York. Web Center Image: Rollei. Saddle Shoes. N.d. Flickr. Web

Left Image: Kubrick, Stanley. Woman on the street. N.d. Museum of the City of New York. Web. 


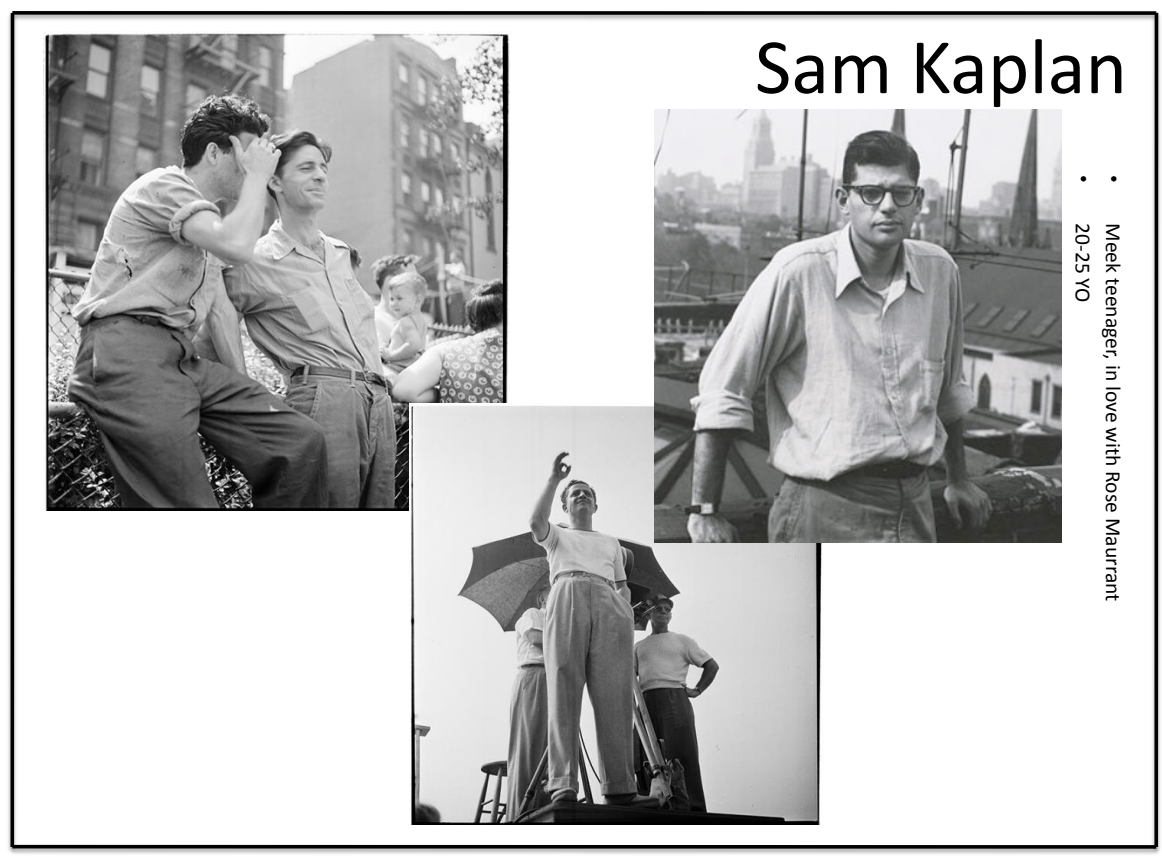

Left Image: Kubrick, Stanley. Naked City [Two men leaning against a fence.] 1947. Museum of the City of New York. Web. Center Image: Kubrick, Stanley. Naked City [Filming the movie]. 1947. Museum of the City of New York. Web. Right Image: Burroughs, W.S. Portrait of Allen Ginsberg. 1953. Howardgreenberg.com. Web.

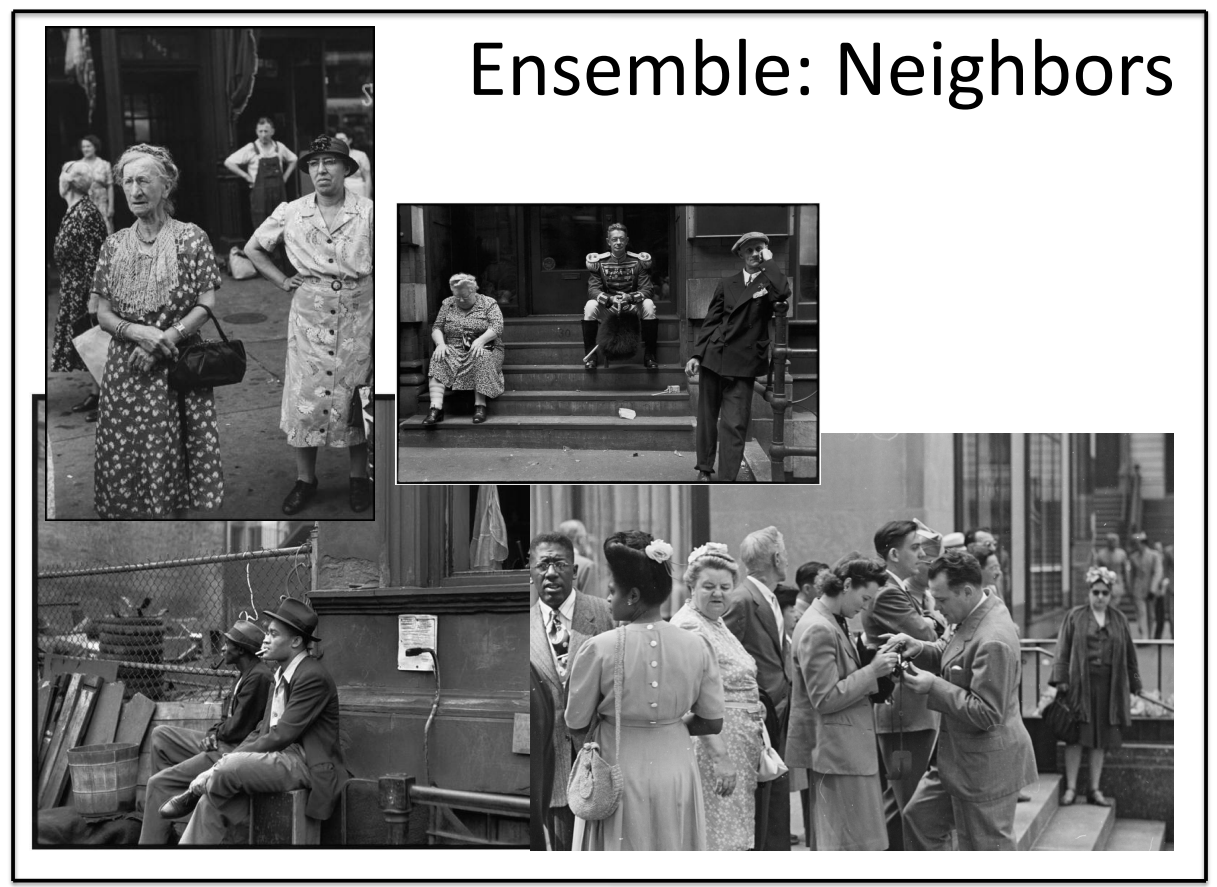

Top Left Image: Cartier-Bresson, Henri. USA. New York City. American Legion Parade. 1947. Magnum Photos. Web Bottom Left Image: Cartier-Bresson, Henri. USA. New York City. Harlem. 1947. Magnum Photos. Web Center Image: Cartier-Bresson, Henri. USA. New York City. American Legion Parade. 1947. Magnum Photos. Web Right Image: Hansen, Bob. Everyone is Taking Pictures, Woman and Man Looking at a Camera. 1946. Museum of the City of New York. Web. 


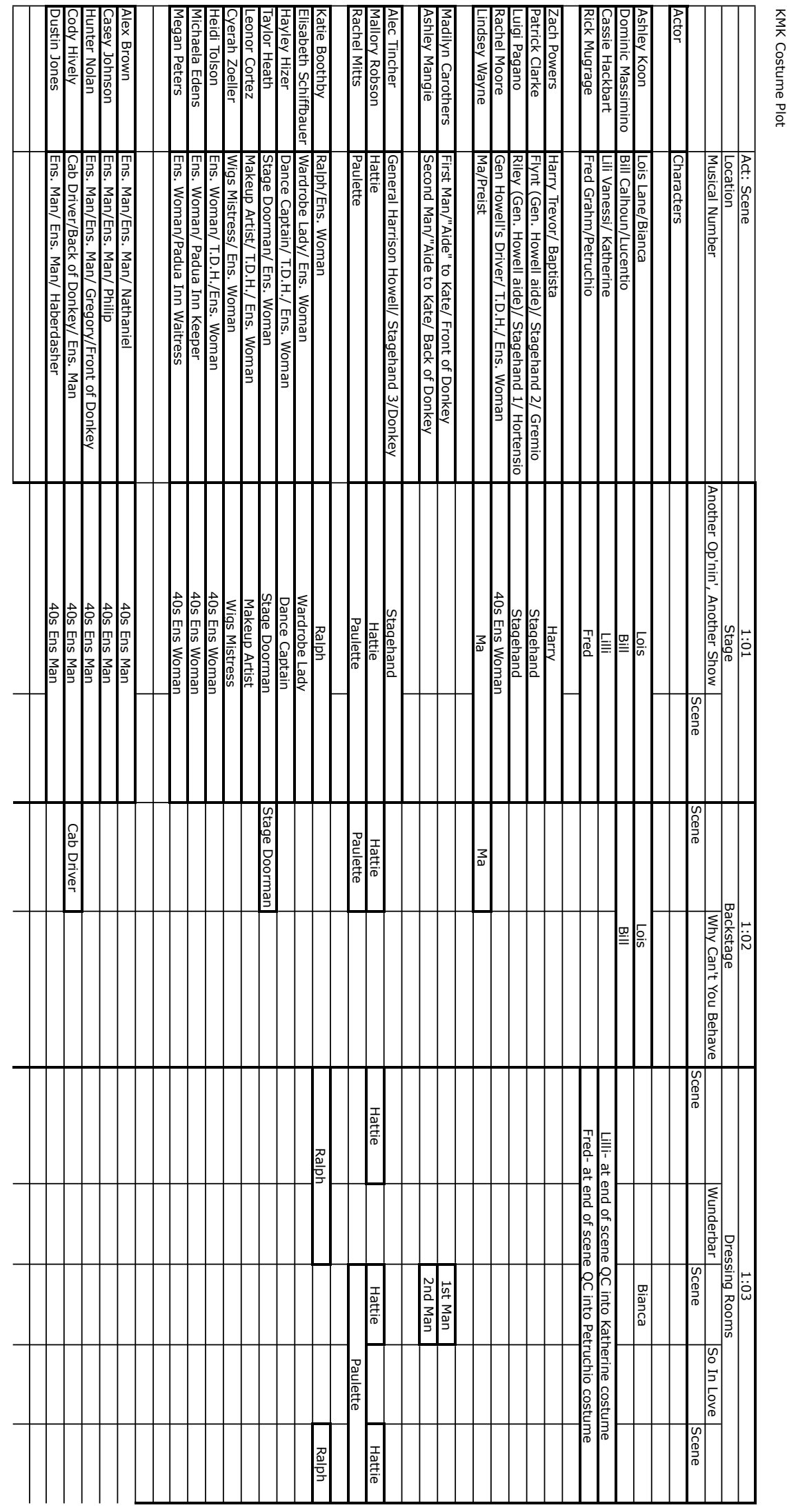


Appendix D: Wardrobe Crew Costume Plot

Costume Plot

Kiss Me Kate

Costume Designer: Cecelia Hill

West Virginia University

Director: Bryce Britton

\begin{tabular}{|c|c|c|c|c|}
\hline Act: Scene & Location & Costume Look & Actor & Characters \\
\hline $1: 01$ & Stage & \multirow{2}{*}{ Lois } & Ashley Koon & Lois Lane/Bianca \\
\hline $1: 02$ & Backstage & & & \\
\hline $1: 03$ & Dressing Rooms & \multirow{3}{*}{ Bianca } & \multirow{15}{*}{\multicolumn{2}{|c|}{ * No bodice add robe }} \\
\hline $1: 04$ & Padua & & & \\
\hline $1: 05$ & Padua & & & \\
\hline $1: 06$ & Backstage & & & \\
\hline $1: 07$ & Dressing Rooms & & & \\
\hline $1: 08$ & Padua & & & \\
\hline $1: 09$ & Padua & Bianca & & \\
\hline $2: 01$ & Alley & Bianca & & \\
\hline $2: 02$ & Show Curtain & & & \\
\hline $2: 03$ & Pertuchio's House & & & \\
\hline $2: 04$ & Backstage & Bianca & & \\
\hline $2: 05$ & Dressing Rooms & & & \\
\hline $2: 06$ & Backstage & Bianca & & \\
\hline $2: 07$ & Show Curtain & & & \\
\hline $2: 08$ & Padua & Bianca & & \\
\hline
\end{tabular}

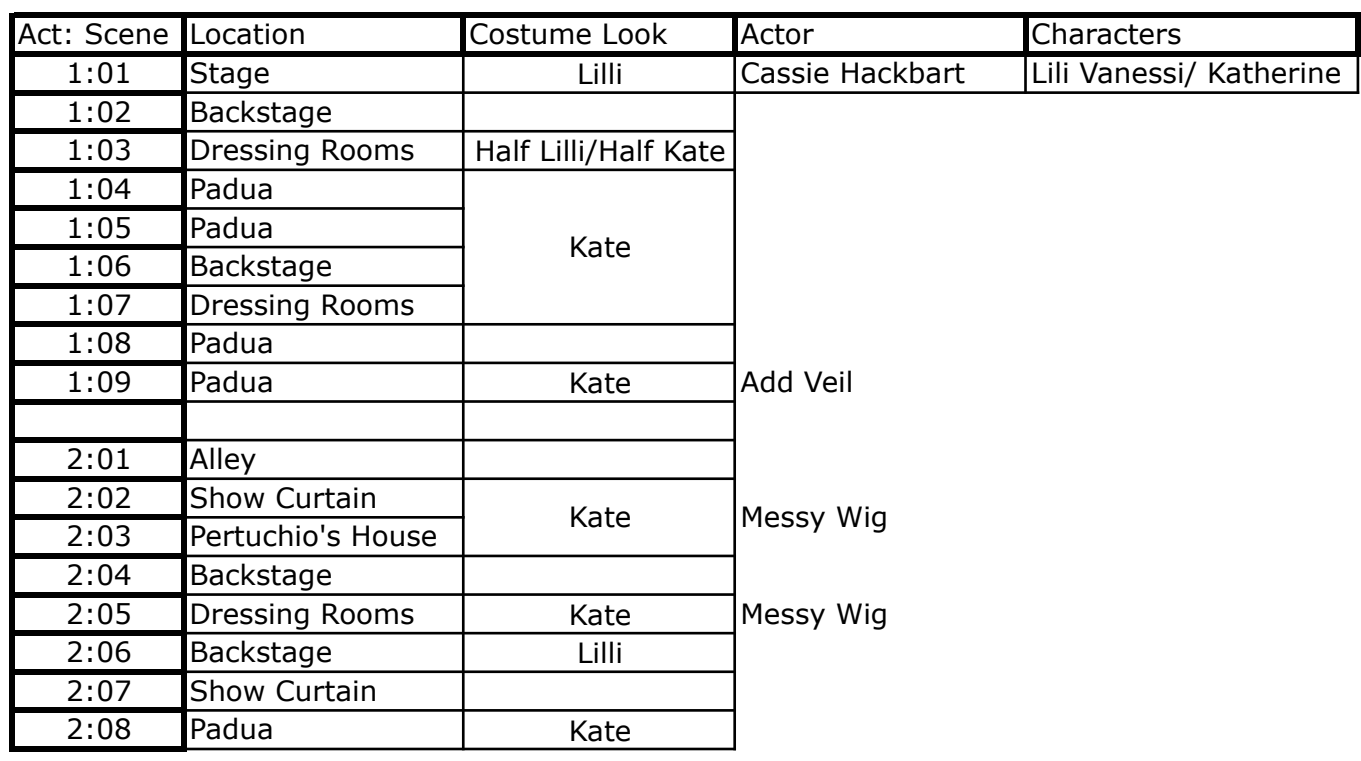


Kiss Me Kate

West Virginia University
Costume Designer: Cecelia Hill Director: Bryce Britton

\begin{tabular}{|c|c|c|c|c|}
\hline Act: Scene & Location & Costume Look & Actor & Characters \\
\hline $1: 01$ & Stage & \multirow{2}{*}{ Bill } & Dominic Massimino & Bill Calhoun/Lucentio \\
\hline $1: 02$ & Backstage & & \multirow{16}{*}{ * No doublet } & \\
\hline $1: 03$ & Dressing Rooms & & & \\
\hline $1: 04$ & Padua & \multirow{2}{*}{ Lucentio } & & \\
\hline $1: 05$ & Padua & & & \\
\hline $1: 06$ & Backstage & & & \\
\hline $1: 07$ & Dressing Rooms & & & \\
\hline $1: 08$ & Padua & & & \\
\hline $1: 09$ & Padua & Lucentio & & \\
\hline $2: 01$ & Alley & Lucentio & & \\
\hline $2: 02$ & Show Curtain & & & \\
\hline $2: 03$ & Pertuchio's House & & & \\
\hline $2: 04$ & Backstage & Lucentio & & \\
\hline $2: 05$ & Dressing Rooms & & & \\
\hline $2: 06$ & Backstage & Lucentio & & \\
\hline $2: 07$ & Show Curtain & & & \\
\hline $2: 08$ & Padua & Lucentio & & \\
\hline
\end{tabular}

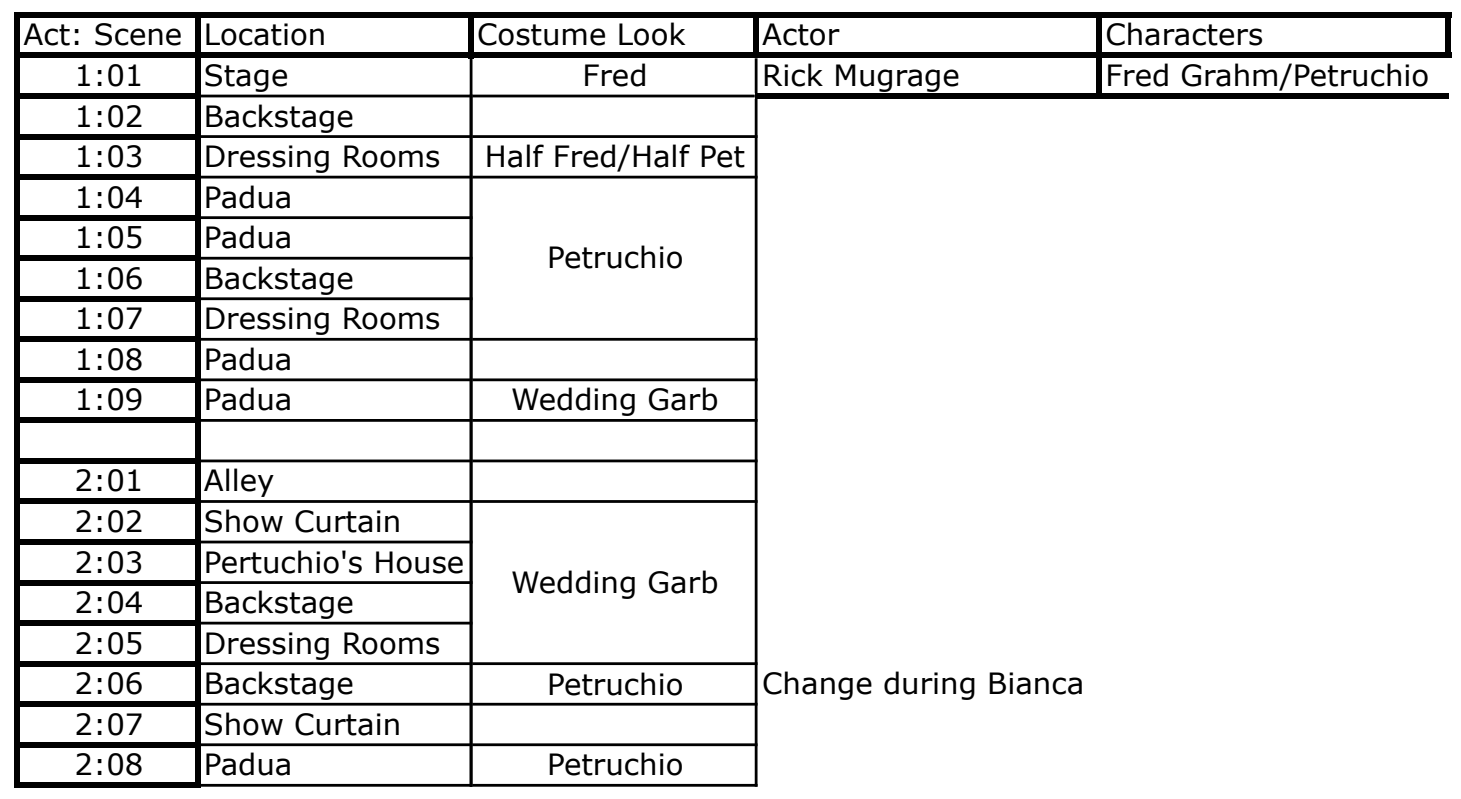


Kiss Me Kate

West Virginia University
Costume Designer: Cecelia Hill Director: Bryce Britton

\begin{tabular}{|c|c|c|c|c|}
\hline Act: Scene & Location & Costume Look & Actor & Characters \\
\hline $1: 01$ & Stage & Harry & Zach Powers & Harry Trevor/ Baptista \\
\hline $1: 02$ & Backstage & & \multirow{16}{*}{ * no doublet } & \\
\hline $1: 03$ & Dressing Rooms & & & \\
\hline $1: 04$ & Padua & & & \\
\hline $1: 05$ & Padua & Baptista & & \\
\hline $1: 06$ & Backstage & & & \\
\hline $1: 07$ & Dressing Rooms & & & \\
\hline $1: 08$ & Padua & & & \\
\hline $1: 09$ & Padua & Baptista & & \\
\hline $2: 01$ & Alley & Baptista & & \\
\hline $2: 02$ & Show Curtain & & & \\
\hline $2: 03$ & Pertuchio's House & & & \\
\hline $2: 04$ & Backstage & & & \\
\hline $2: 05$ & Dressing Rooms & & & \\
\hline $2: 06$ & Backstage & & & \\
\hline $2: 07$ & Show Curtain & & & \\
\hline $2: 08$ & Padua & Baptista & & \\
\hline
\end{tabular}

\begin{tabular}{|c|c|c|c|c|}
\hline Act: Scene & Location & Costume Look & Actor & Characters \\
\hline $1: 01$ & Stage & Stagehand & Alec Tincher & General/ Stagehand/Donkey \\
\hline $1: 02$ & Backstage & & \multirow{17}{*}{ *pants only } & \\
\hline $1: 03$ & Dressing Rooms & & & \\
\hline $1: 04$ & Padua & \multirow{2}{*}{ Donkey } & & \\
\hline $1: 05$ & Padua & & & \\
\hline $1: 06$ & Backstage & & & \\
\hline $1: 07$ & Dressing Rooms & & & \\
\hline $1: 08$ & Padua & & & \\
\hline $1: 09$ & Padua & & & \\
\hline & & \multirow{4}{*}{ Donkey } & & \\
\hline $2: 01$ & Alley & & & \\
\hline $2: 02$ & Show Curtain & & & \\
\hline $2: 03$ & Pertuchio's House & & & \\
\hline $2: 04$ & Backstage & \multirow{3}{*}{ General } & & \\
\hline $2: 05$ & Dressing Rooms & & & \\
\hline $2: 06$ & Backstage & & & \\
\hline $2: 07$ & Show Curtain & & & \\
\hline $2: 08$ & Padua & & & \\
\hline
\end{tabular}


Appendix E: Piece List

Piece List

Kiss Me Kate

West Virginia University

Costume Designer: Cecelia Hill Director: Bryce Britton

\begin{tabular}{|c|c|c|}
\hline Actor & Character & Pieces \\
\hline \multirow[t]{19}{*}{ Cassie Hackbart } & Lili Vanessi & \\
\hline & & Dress \\
\hline & & Slip \\
\hline & & Gloves \\
\hline & & Wrap \\
\hline & & Tights \\
\hline & & Hat \\
\hline & & Jewelry- Necklace, Earrings, Ring \\
\hline & Katherine & \\
\hline & & Corset \\
\hline & & Petticoats $\times 3$ \\
\hline & & Bum Roll \\
\hline & & Bodice \\
\hline & & Skirt \\
\hline & & Shoes \\
\hline & & Jewelry- Necklace \& Earrings \\
\hline & & Bloomers \\
\hline & K-Wlodding & \\
\hline & 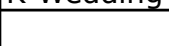 & Veil \\
\hline & & \\
\hline
\end{tabular}

\begin{tabular}{|l|l|l|}
\hline Ashley Koon & Lois Lane & \\
\hline & & Dress \\
\hline & & All-In- One \\
\hline & & Tights \\
\hline & & Shoes \\
\hline & & Jewelry- Bracelet \& Earrings \\
\hline & Bianca & \\
\hline & & Corset \\
\hline & & Petticoats x3 \\
\hline & & Bum Roll \\
\hline & & Bodice \\
\hline & & Skirt \\
\hline & & Shoes \\
\hline & & Jewelry- Necklace \& Earrings \\
\hline & & Shorts \\
\hline & & \\
\hline & B- Wedding & Floral Wreath \\
\hline & &
\end{tabular}


Piece List

Kiss Me Kate

West Virginia University
Costume Designer: Cecelia Hill Director: Bryce Britton

\begin{tabular}{|c|c|c|}
\hline Actor & Character & Pieces \\
\hline \multirow[t]{21}{*}{ Rick Mugrage } & Fred Grahm & \\
\hline & & 2 Pc. Suit \\
\hline & & White Dress Shirt \\
\hline & & Tie \\
\hline & & Undershirt \\
\hline & & Socks \\
\hline & & Shoes \\
\hline & Petruchio & \\
\hline & & Doublet \\
\hline & & Pumpkin Breeches \\
\hline & & Hose \\
\hline & & Shoes \\
\hline & & Hat \\
\hline & & \\
\hline & P-Wedding & \\
\hline & & Vest \\
\hline & & Shirt \\
\hline & & Gold Leggings \\
\hline & & Cod Piece \\
\hline & & Two different Boots \\
\hline & & Hat \\
\hline \multirow[t]{15}{*}{ Dominic Massimino } & Bill Calhoun & \\
\hline & & 2 Pc Suit \\
\hline & & White Dress Shirt \\
\hline & & Undershirt \\
\hline & & Tie \\
\hline & & Socks \\
\hline & & Shoes \\
\hline & Lucentio & \\
\hline & & Doublet \\
\hline & & Pumpkin Breeches \\
\hline & & Hose \\
\hline & & Shoes \\
\hline & & Hat \\
\hline & & \\
\hline & & \\
\hline
\end{tabular}


Piece List

Kiss Me Kate

West Virginia University
Costume Designer: Cecelia Hill Director: Bryce Britton

\begin{tabular}{|c|c|c|}
\hline Actor & Character & Pieces \\
\hline \multirow[t]{18}{*}{ Zach Powers } & Harry Trevor & \\
\hline & & 2 Pc. Suit \\
\hline & & White Dress Shirt \\
\hline & & Tie \\
\hline & & Undershirt \\
\hline & & Socks \\
\hline & & Glasses \\
\hline & & Shoes \\
\hline & & \\
\hline & Baptista & \\
\hline & & Doublet \\
\hline & & Cape \\
\hline & & Body Padding \\
\hline & & Pumpkin Breeches \\
\hline & & Hose \\
\hline & & Shoes \\
\hline & & Collar of Office \\
\hline & & Hat \\
\hline \multirow[t]{24}{*}{ Patrick Clarke } & Flynt & \\
\hline & & Soldier Shirt \\
\hline & & Soldier Pants \\
\hline & & Belt \\
\hline & & Envelope Hat \\
\hline & & Undershirt \\
\hline & & Socks \\
\hline & & Shoes \\
\hline & & \\
\hline & Stagehand \#2 & \\
\hline & & Button Up Shirt \\
\hline & & Undershirt \\
\hline & & Belt \\
\hline & & Pants \\
\hline & & Socks \\
\hline & & Shoes \\
\hline & & Cap \\
\hline & \begin{tabular}{|l} 
Gremio \\
\end{tabular} & \\
\hline & & Doublet \\
\hline & & Shirt \\
\hline & & Breeches \\
\hline & & Hose \\
\hline & & Shoes \\
\hline & & Hat \\
\hline
\end{tabular}


Appendix F: Initial Budget Estimate

Budget Estimate

Kiss Me Kate

West Virginia University
Costume Designer: Cecelia Hill Director: Bryce Britton

\begin{tabular}{|c|c|c|c|c|c|c|}
\hline Actor & Character & Wigs & Hats & Build Total & Rent Total & Cost Total \\
\hline & & & & & & \\
\hline & Fred/Petruchio & & 2 & 4 & & $\$ 242$ \\
\hline & \begin{tabular}{|l|} 
Lili/Katherine \\
\end{tabular} & 3 & 3 & 3 & & $\$ 394$ \\
\hline & Lois/Bianca & 1 & & 3 & & $\$ 274$ \\
\hline & Bill/Lucentio & & 1 & 4 & & $\$ 242$ \\
\hline & Pops/Padua Preist & $*$ & 1 & & 3 & $\$ 91$ \\
\hline & First Man/Aide/Donkey & & 2 & & 5 & $\$ 627$ \\
\hline & Second Man/Aide/Donkey & & 2 & & 5 & $\$ 127$ \\
\hline & Harry Trevor/Baptista & & 1 & 6 & & $\$ 417$ \\
\hline & Dance Captain/Gregory & & & & 3 & $\$ 109$ \\
\hline & Flynt/Gremio & & 2 & 4 & & $\$ 242$ \\
\hline & Riley/Hortensio & & 2 & 4 & & $\$ 242$ \\
\hline & SH1/Cab Driver/Nathaniel & & 2 & & 3 & $\$ 109$ \\
\hline & Gen. Harrison Howell & & 1 & & & 0 \\
\hline & Hattie & & & & & 0 \\
\hline & Paul & & & & & 0 \\
\hline & SH2/Phillip & & 1 & & 3 & $\$ 109$ \\
\hline & SH3/Driver/Habadasher & & 2 & & 4 & $\$ 166$ \\
\hline & Ralph/Ens. Man & & & & 3 & $\$ 83$ \\
\hline & Wardrobe Lady/Ens. Woman & 1 & 1 & & 6 & $\$ 117$ \\
\hline & Woman Singer 1/Padua Inn Waitress & 1 & & & 5 & $\$ 99$ \\
\hline & Woman Singer 2/Ens. Woman & 1 & & & 5 & $\$ 99$ \\
\hline & Woman Singer 3/Ens. Woman & & 2 & & 7 & $\$ 115$ \\
\hline & Woman Dancer 1/Ens. Woman & 1 & & & 5 & $\$ 129$ \\
\hline & Woman Dancer 2/Ens. Woman & 1 & & & 5 & $\$ 129$ \\
\hline & Woman Dancer 3/Ens. Woman & 1 & 1 & & 6 & $\$ 147$ \\
\hline & Woman Dancer 4/Ens. Woman & 1 & & & 5 & $\$ 129$ \\
\hline & Ens. Man/Padua Innkeeper & & 1 & & 5 & $\$ 166$ \\
\hline & Ens. Man/Man of Padua/Suitor 1 & & 1 & & 4 & $\$ 114$ \\
\hline & Ens. Man/Man of Padua/Suitor 2 & & 1 & & 4 & $\$ 101$ \\
\hline & Ens. Man/Man of Padua/Suitor 3 & & & & 4 & $\$ 120$ \\
\hline & Dry Cleaning & & & & & $\$ 700$ \\
\hline & & & & & & \\
\hline & Totals & 11 & 29 & 28 & 90 & $\$ 5,639$ \\
\hline
\end{tabular}


Final Budget
Kiss Me Kate

West Virginia University
Costume Designer: Cecelia Hill Director: Bryce Britton

\begin{tabular}{|c|c|c|}
\hline Actor & Character & Totals \\
\hline Rick Mugrage & Fred/Petruchio & $\$ 168.86$ \\
\hline Cassie Hackbart & Lili/Katherine & $\$ 175.09$ \\
\hline Ashley Koon & Lois/Bianca & $\$ 253.60$ \\
\hline Dominic Massimino & Bill/Lucentio & $\$ 103.39$ \\
\hline Lindsey Wayne & Pops/Padua Preist & $\$ 48.97$ \\
\hline Madilyn Carothers & First Man/Aide/Donkey & $\$ 252.77$ \\
\hline Ashley Mangie & Second Man/Aide/Donkey & $\$ 182.66$ \\
\hline Zach Powers & Harry Trevor/Baptista & $\$ 98.30$ \\
\hline Hayley Hizer & Dance Captain/Ens Woman & $\$ 37.55$ \\
\hline Patrick Clarke & Flynt/Gremio/SH1 & $\$ 216.65$ \\
\hline Luigi Pagano & Riley/Hortensio/SH2 & $\$ 161.88$ \\
\hline Cody Hively & Cab Driver/Back of Donkey/Ens Man & $\$ 31.03$ \\
\hline Alec Tincher & Gen. Harrison Howell/SH3 & $\$ 14.96$ \\
\hline Mallory Robson & Hattie & 0 \\
\hline Rachel Mitts & Paulette & $\$ 23.48$ \\
\hline Rachel Moore & Driver/TDH Dancer/Ens Woman & $\$ 73.57$ \\
\hline Dustin Jones & Ens Man/Haberdasher/Ens Man & $\$ 31.03$ \\
\hline Katie Boothby & Ralph/Ens. Woman & $\$ 14.96$ \\
\hline Elisabeth Schiffbauer & Wardrobe Lady/Ens. Woman & 0 \\
\hline Heidi Tolson & Ens Woman/TDH Dancer/Ens Woman & $\$ 31.89$ \\
\hline Taylor Heath & Doorwoman/Ens Woman & 0 \\
\hline Megan Peters & Ens Woman/Padua Inn Waitress & 0 \\
\hline Cyerah Zoeller & Wigs Mistress/Ens Woman & $\$ 17.90$ \\
\hline Leonor Cortez & Makeup Woman/TDH Dancer/Ens Woman & $\$ 17.90$ \\
\hline Michaela Edens & Ens Woman/Padua Innkeeper & $\$ 94.87$ \\
\hline Alex Brown & Ens Man/Nathaniel/Ens Man & $\$ 172.92$ \\
\hline Casey Johnson & Ens Man/Phillip/ Ens Man & $\$ 129.07$ \\
\hline \multirow[t]{5}{*}{ Hunter Nolan } & Ens Man/Gregory/Front of Donkey/Ens Man & $\$ 79.82$ \\
\hline & Shipping & $\$ 180.07$ \\
\hline & Shop Supplies \& Misc. & $\$ 1,504.25$ \\
\hline & Dry Cleaning & $\$ 731.50$ \\
\hline & Totals & $\$ 4,913.80$ \\
\hline
\end{tabular}




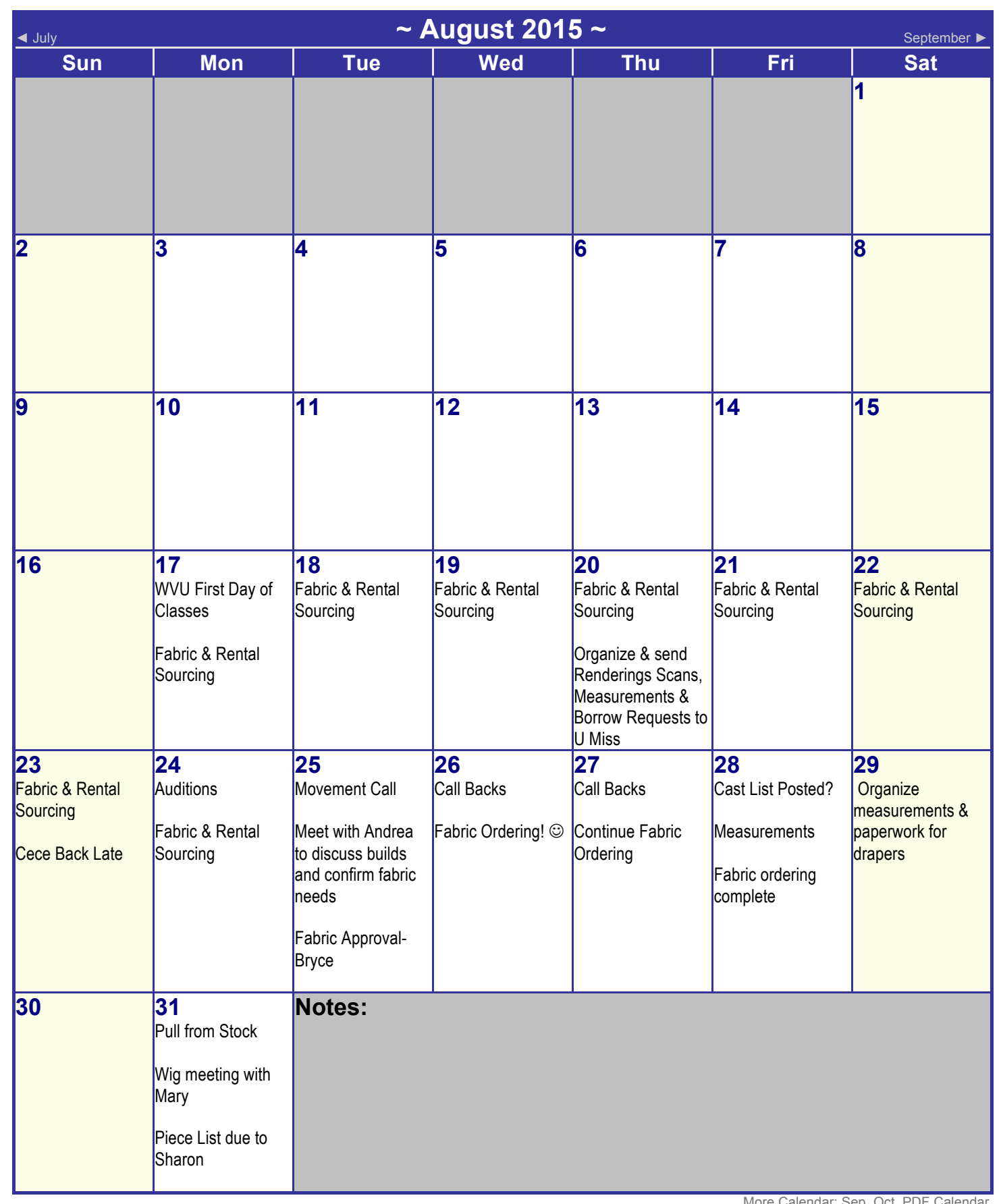




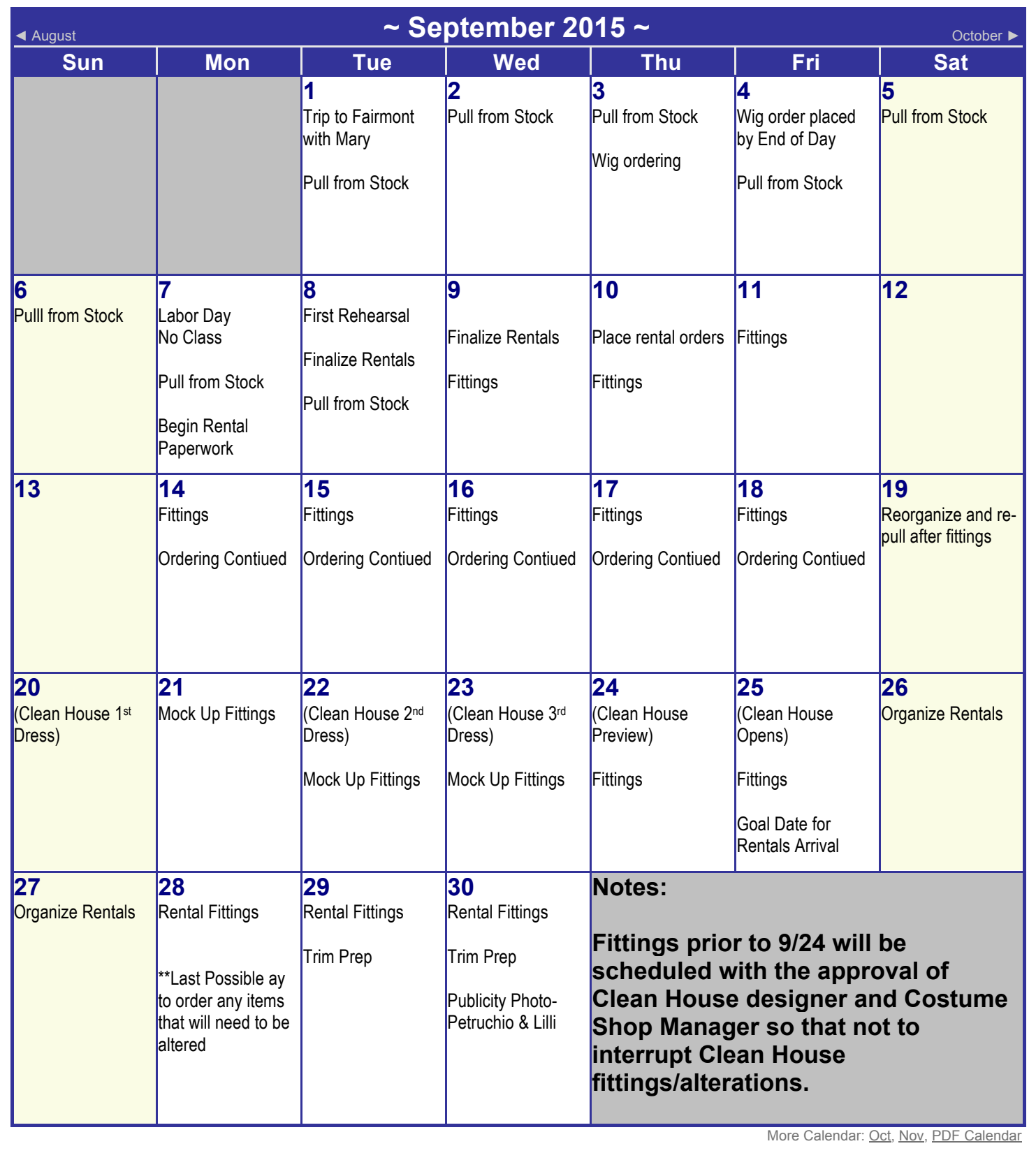




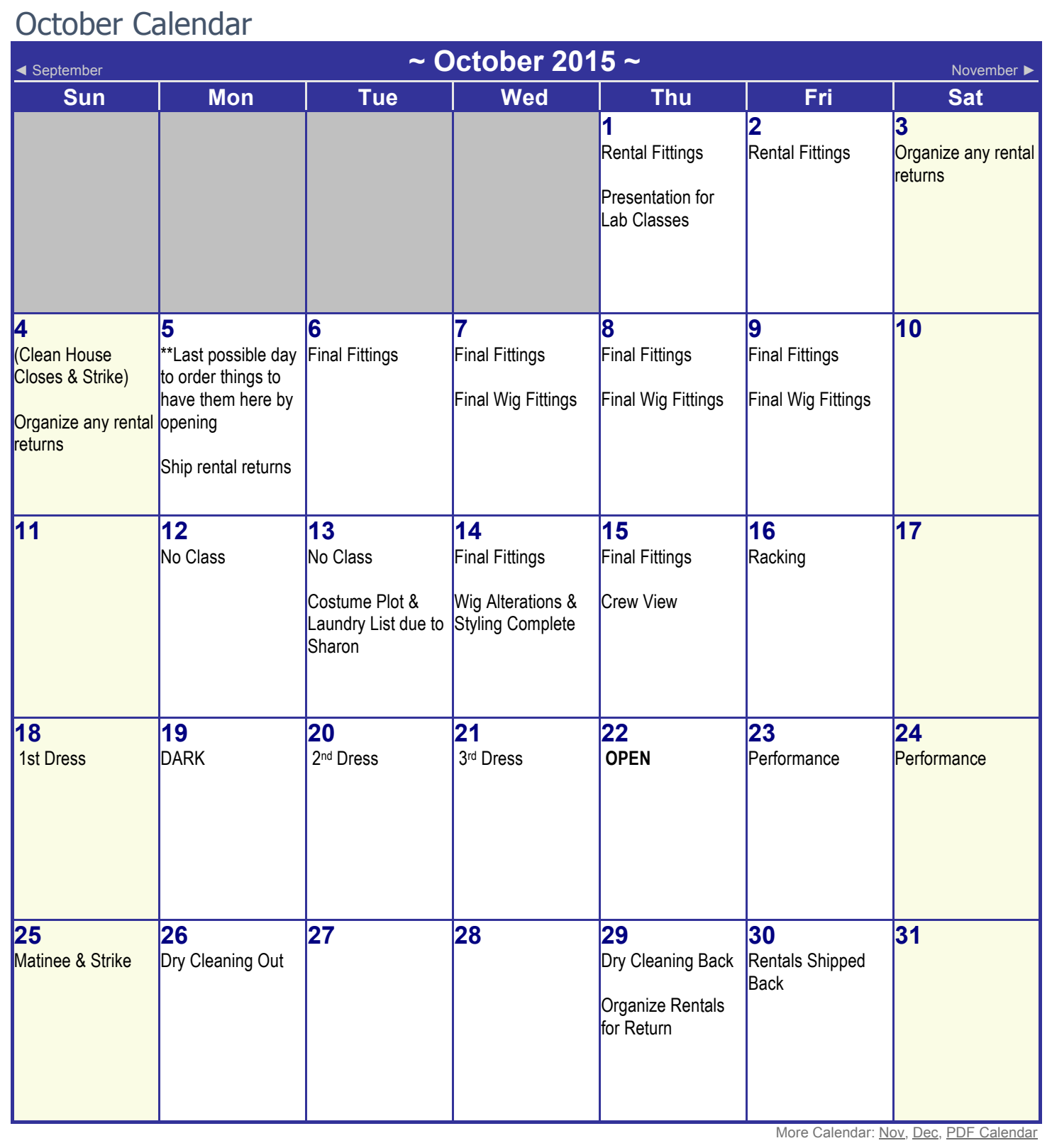




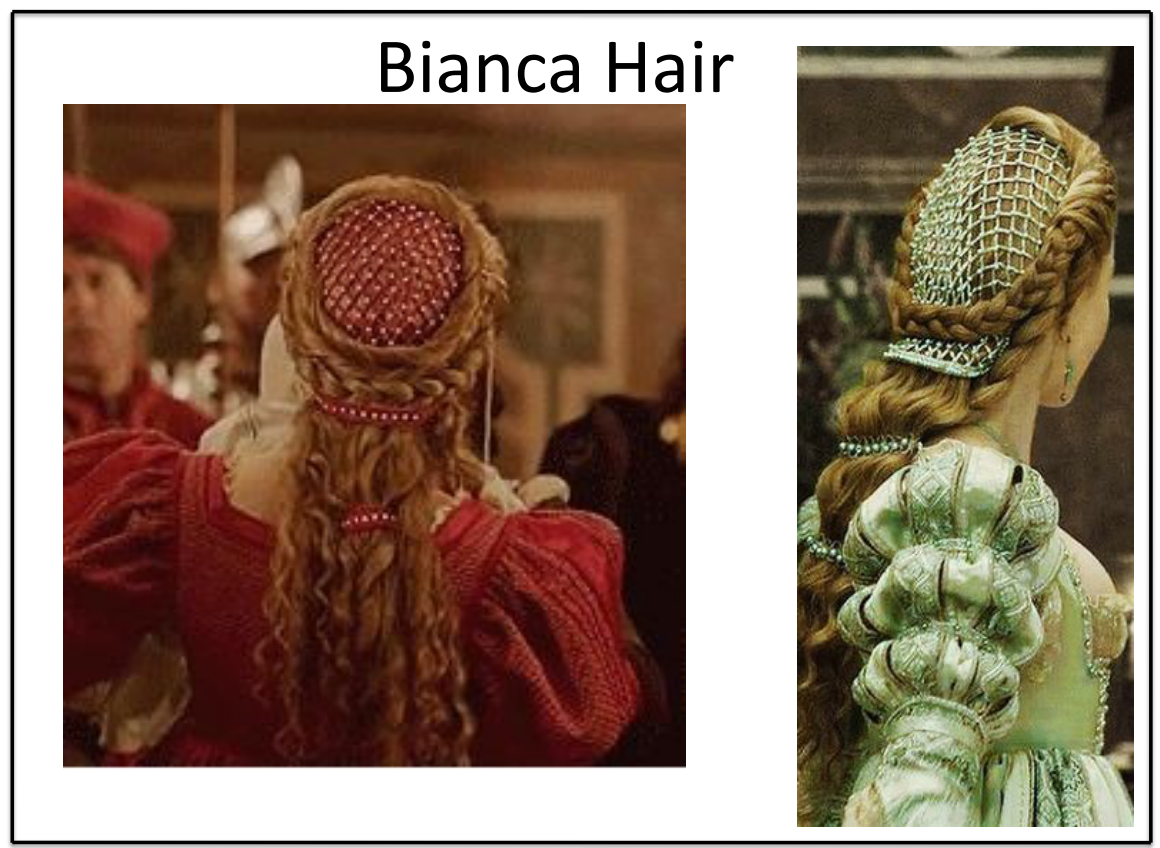

Left Image: Unknown. Lucrezia Borgia. N.d. Closet of the Borgia Ladies. Web.

Right Image: Unknown. The Borgias. N.d. The Modern Duchess. Web

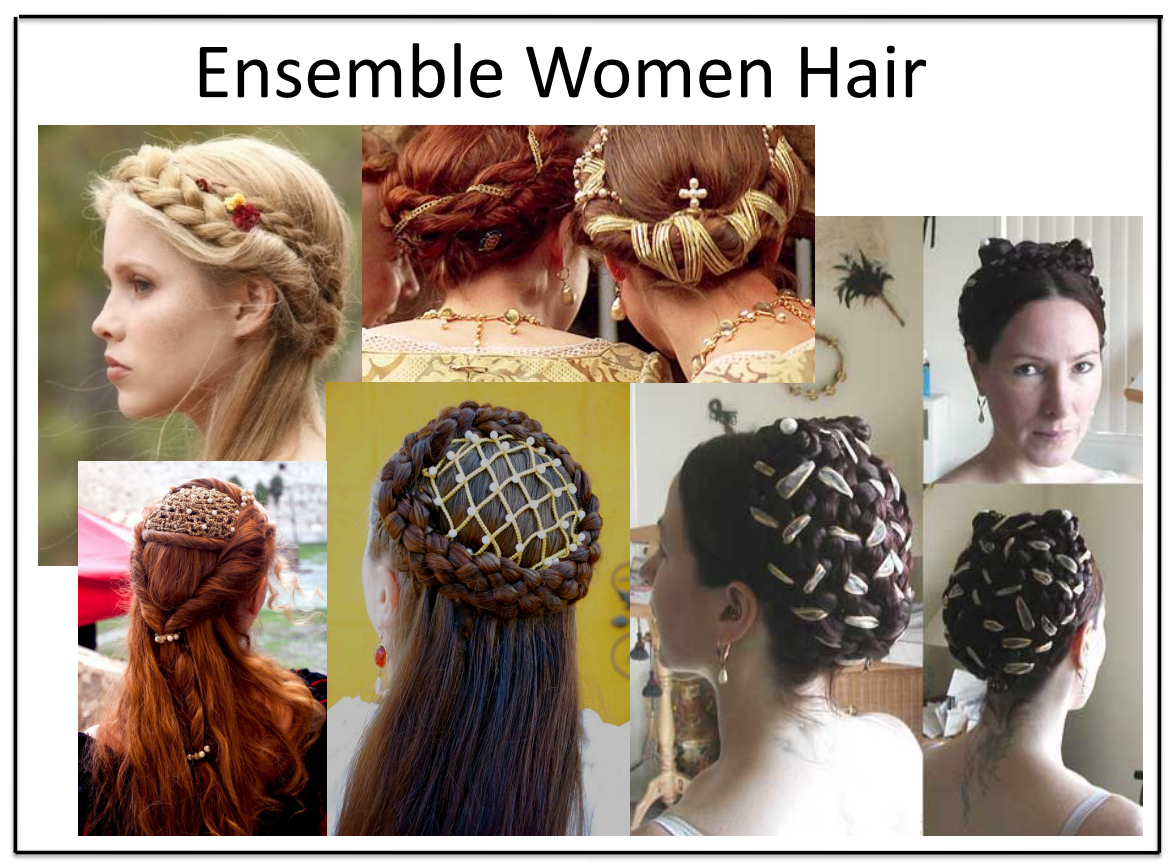

Top Left Image: Unknown. The Vampire Diaries, Claire Holt. N.d. Historical Hairstyles. Web. Top Center Image: Holub, Will. Elizabeth. 2014. That Woman is Me. Web.

Bottom Left Image: Unknown. Medieval Hair. N.d. European Millinery Styles. Web.

Bottom Center Image: Unknown. Braids and Hairnet. N.d. Mr. Costumes. Web.

Right Images: Unknown. Braided Hairstyle. N.d. Italian Showcase. Web. 


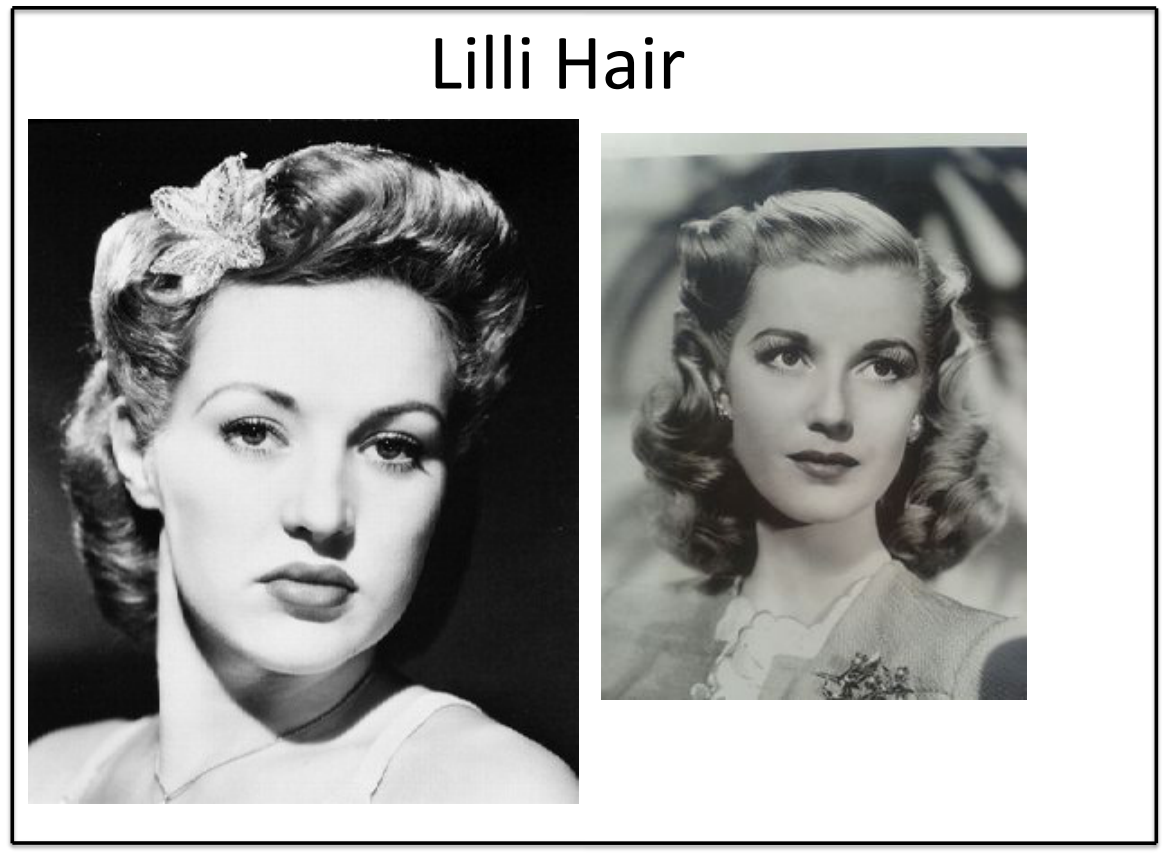

Left Image: Unknown. Betty Grable. N.d. Love Those Classic Movies. Web. Right Image: Unknown. 1940s Hairstyle. N.d. V Is For Vintage. Web.

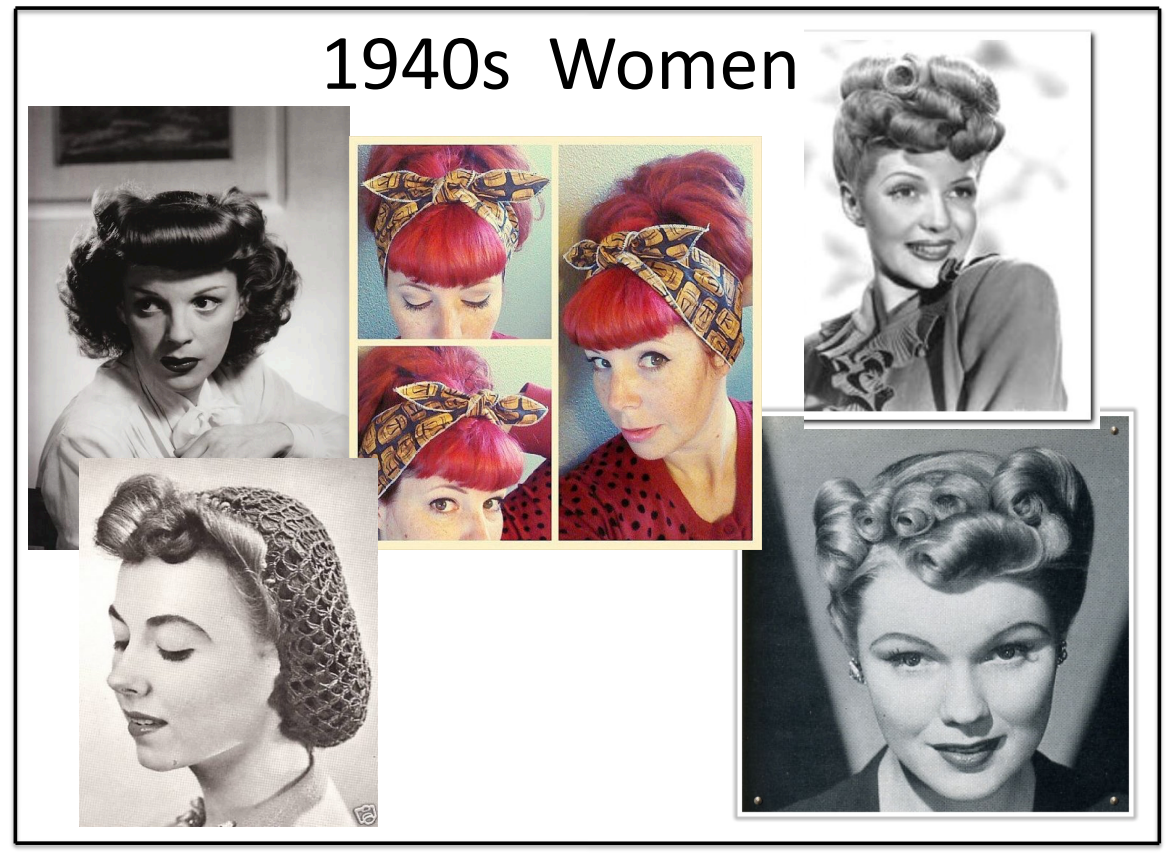

Top Left Image: Halsman, Philippe. American Actress and Singer Judy Garland. 1944. Magnum Photos. Web. Top Right Image: Unknown. Fabulous 1940s Box Braided Hairstyle. N.d. Vintage Hairstyles. Web. Center Image: Unknown. 1940s Hairstyle with bandana. N.d. Pinterest. Web. Bottom Left Image: Unknown. Vintage Snood Hairnet. N.d. Popscreen. Web. Bottom Right Image: Unknown. Basic Reverse Side Roll. N.d. Vintage Hair. Web 


\section{Appendix K: Quick-Change Teams}

Quick-Change Teams

Kiss Me Kate

Costume Designer: Cecelia Hill

West Virginia University

Director: Bryce Britton

\begin{tabular}{|c|c|c|c|c|}
\hline Act: Scene & Actor & Lead Dresser & \multicolumn{2}{|c|}{ Assisting Dressers } \\
\hline $1: 01$ & Cody & Elise & & \\
\hline \multirow{2}{*}{ 1:02 } & Cassie & Megan & Nieri & \\
\hline & Rick & Donna & Emilee & \\
\hline 1:03 & Ashley K. & Megan & Njeri & \\
\hline $1: 07$ & Katie & Amanda & Caroline & Kayla \\
\hline \multirow{4}{*}{$1: 08$} & Cassie & Megan & & \\
\hline & Rick & Donna & Emilee & Chris \\
\hline & Ashley M. & Njeri & Elise & Kayla \\
\hline & Madilyn & Madison & Deja & Stephan \\
\hline \multirow{4}{*}{ 2:02 } & Alex & Chris & Deja & \\
\hline & Casey & Elise & Madison & \\
\hline & Hunter & Kayla & Amanda & \\
\hline & Dustin & Stephan & & \\
\hline \multirow{4}{*}{ 2:06 } & Cassie & Megan & Caroline & Amanda \\
\hline & Rick & Donna & Emilee & Chris \\
\hline & Madilyn & Madison & Deja & Stephan \\
\hline & Ashley M. & Njeri & Elise & Kayla \\
\hline $2: 06 \& 07$ & Cassie & Megan & Caroline & Amanda \\
\hline
\end{tabular}




\section{Appendix L: Production Stills}

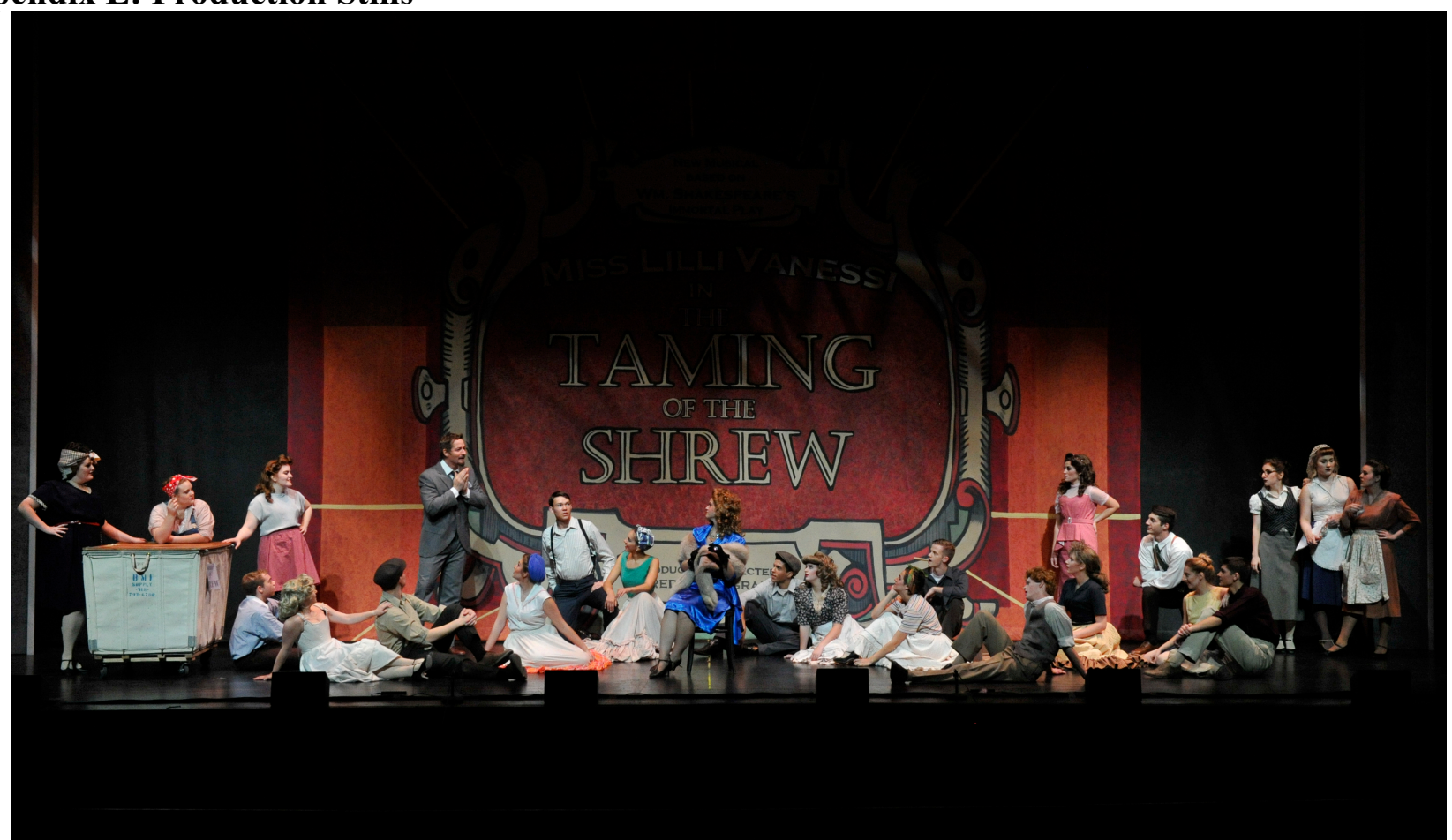

Fred gives the cast and crew notes in front of the show curtain.

West Virginia University Photography. In front of the show curtain. 2015. Photograph. West Virginia University of Theatre and Dance, Morgantown, WV. Digital Image.

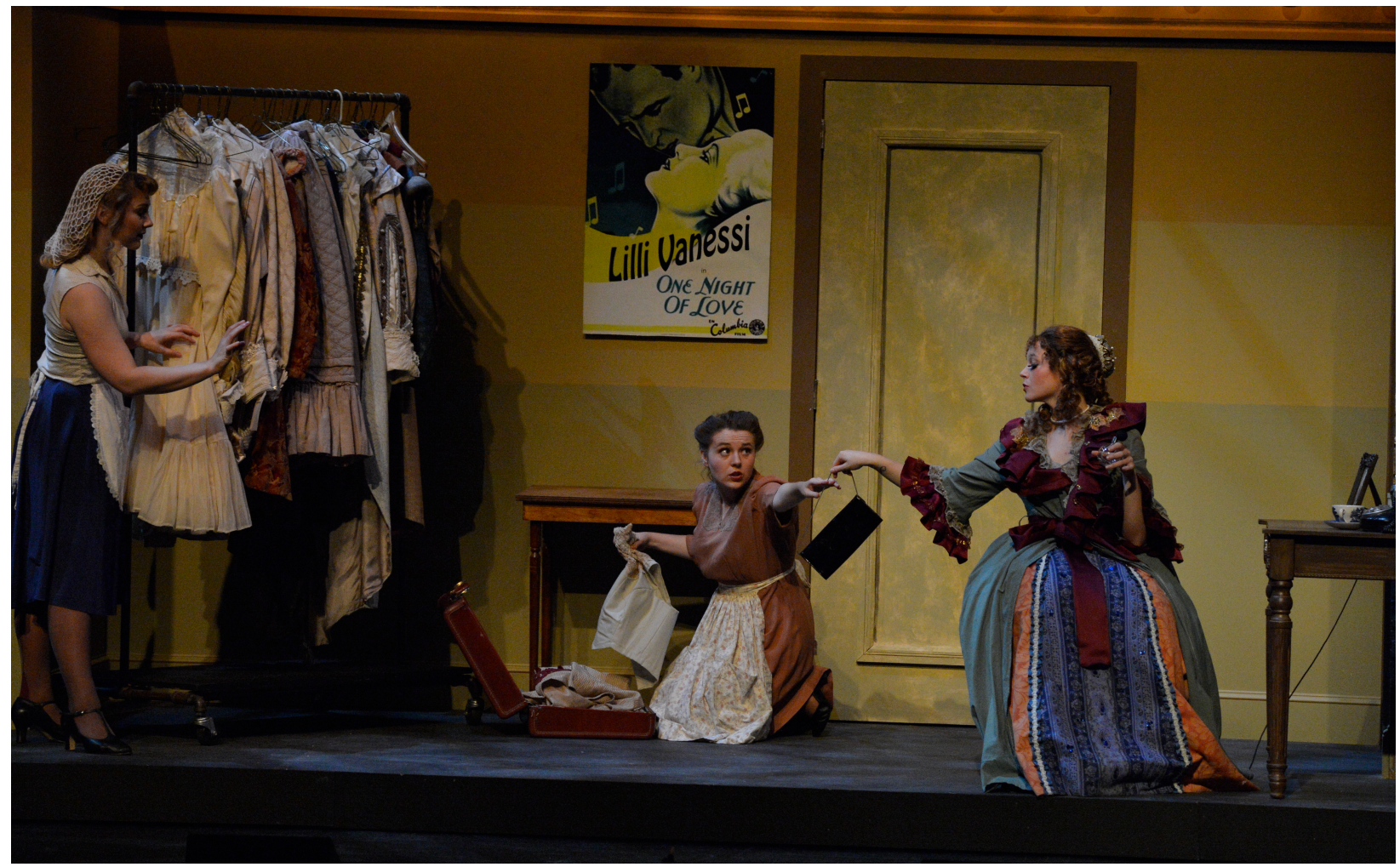

Hattie helps Lilli pack to leave.

West Virginia University Photography. Hattie helps Lilli pack to leave. 2015. Photograph. West Virginia University of Theatre and Dance, Morgantown, WV. Digital Image 


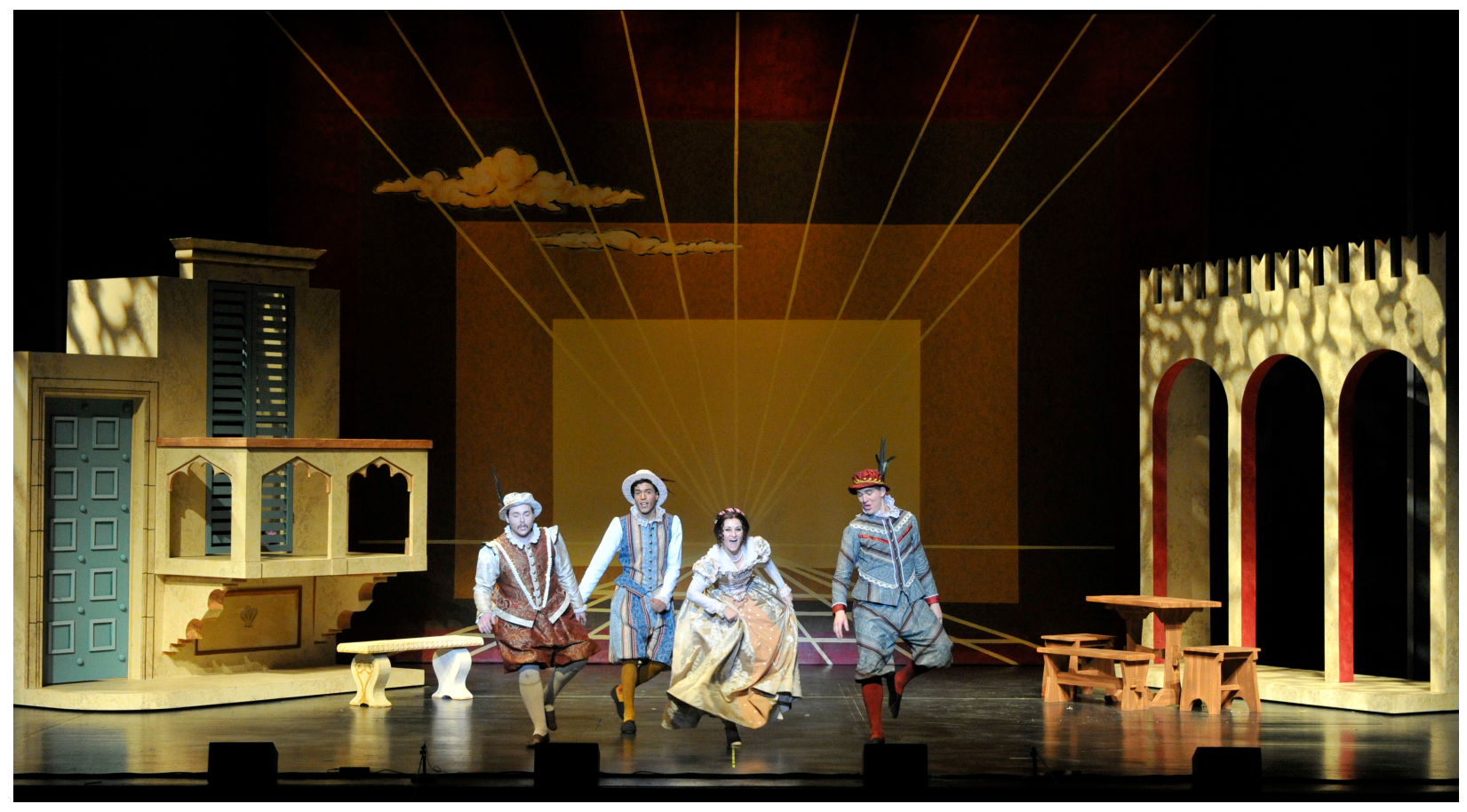

Bianca and her suitors dance during "Tom, Dick, or Harry."

West Virginia University Photography. Tom, Dick, or Harry. 2015. Photograph. West Virginia University of Theatre and Dance, Morgantown, WV. Digital Image

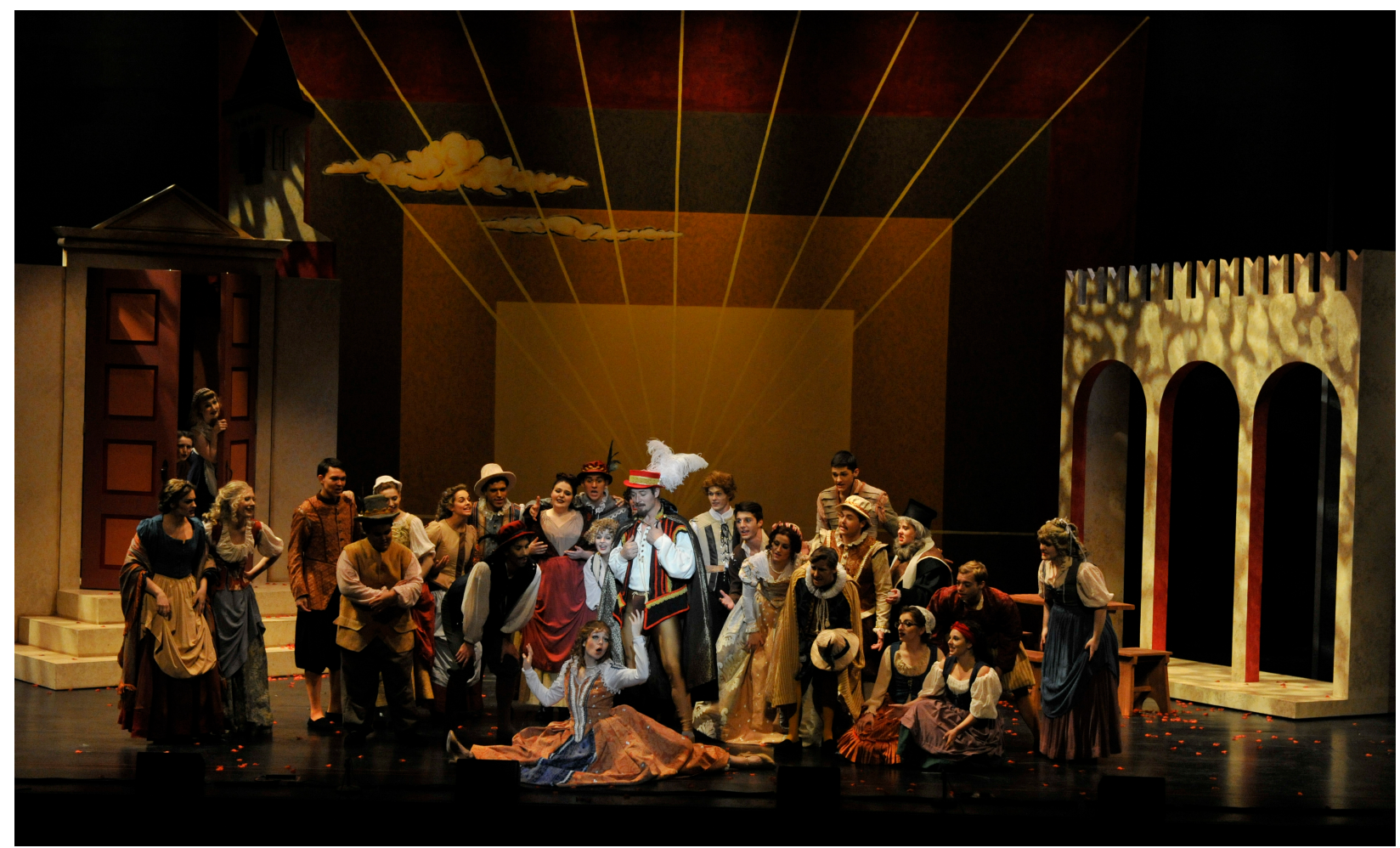

Katherine sings that she will never kiss Petruchio during "Kiss Me Kate."

West Virginia University Photography. Kiss Me Kate. 2015. Photograph. West Virginia University of Theatre and Dance, Morgantown, WV. Digital Image 


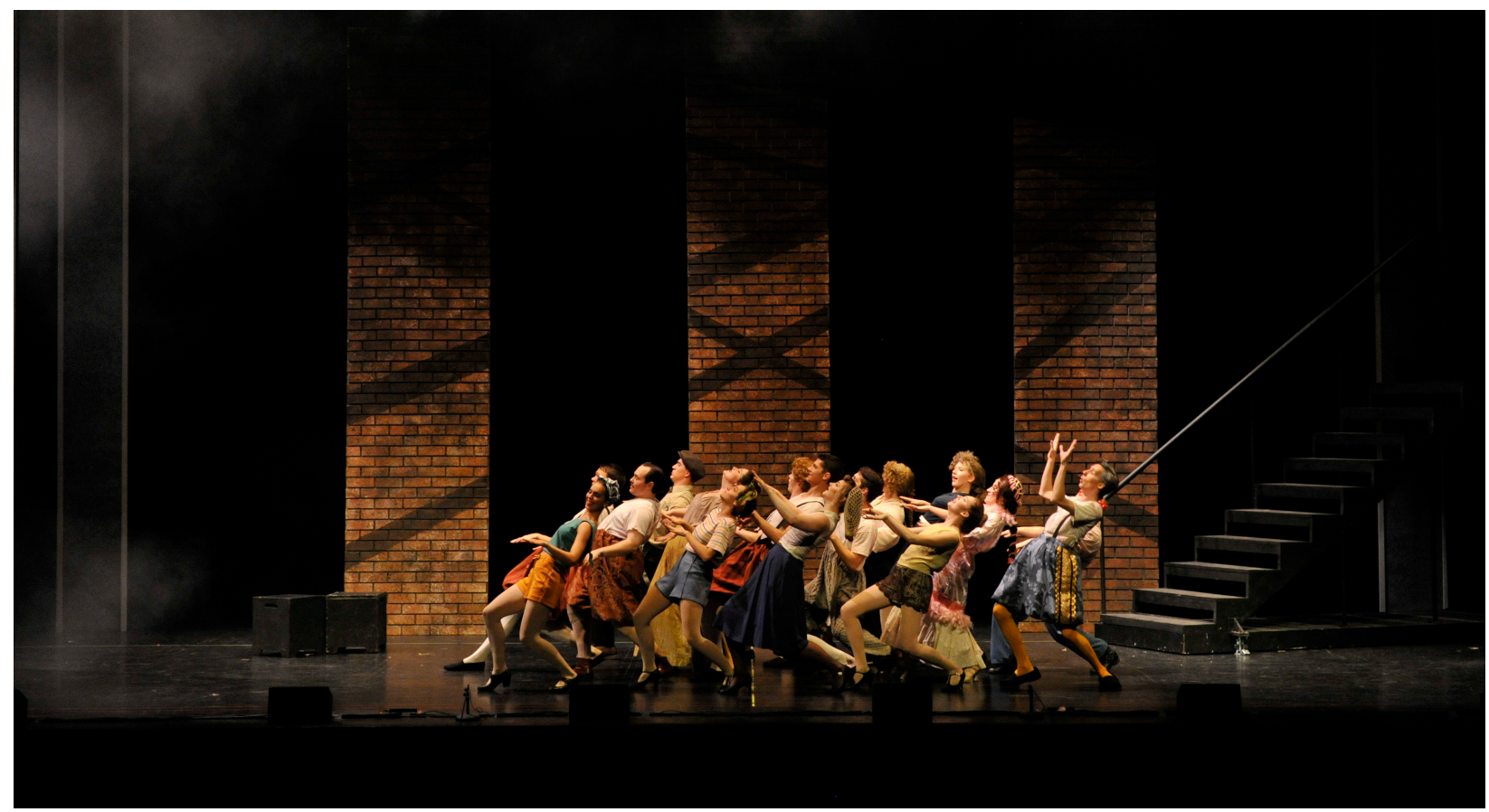

The cast dancing during "Too Darn Hot."

West Virginia University Photography. Too Darn Hot. 2015. Photograph. West Virginia University of Theatre and Dance, Morgantown, WV. Digital Image

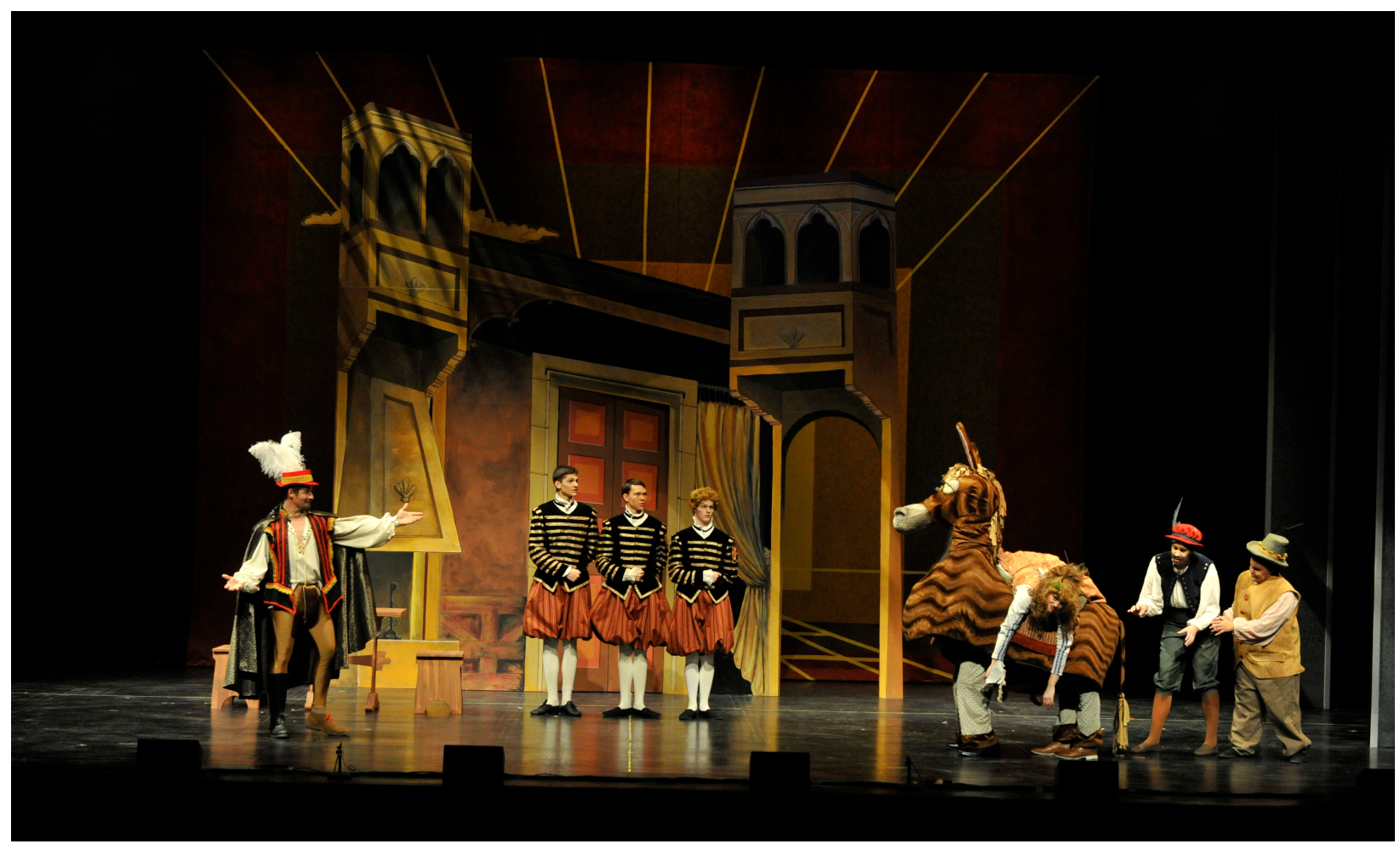

Petruchio and Kate arrive at Petruchio's House.

West Viginia University Photography. Petruchio's House. 2015. Photograph. West Virginia University of Theatre and Dance, Morgantown, WV. Digital Image. 


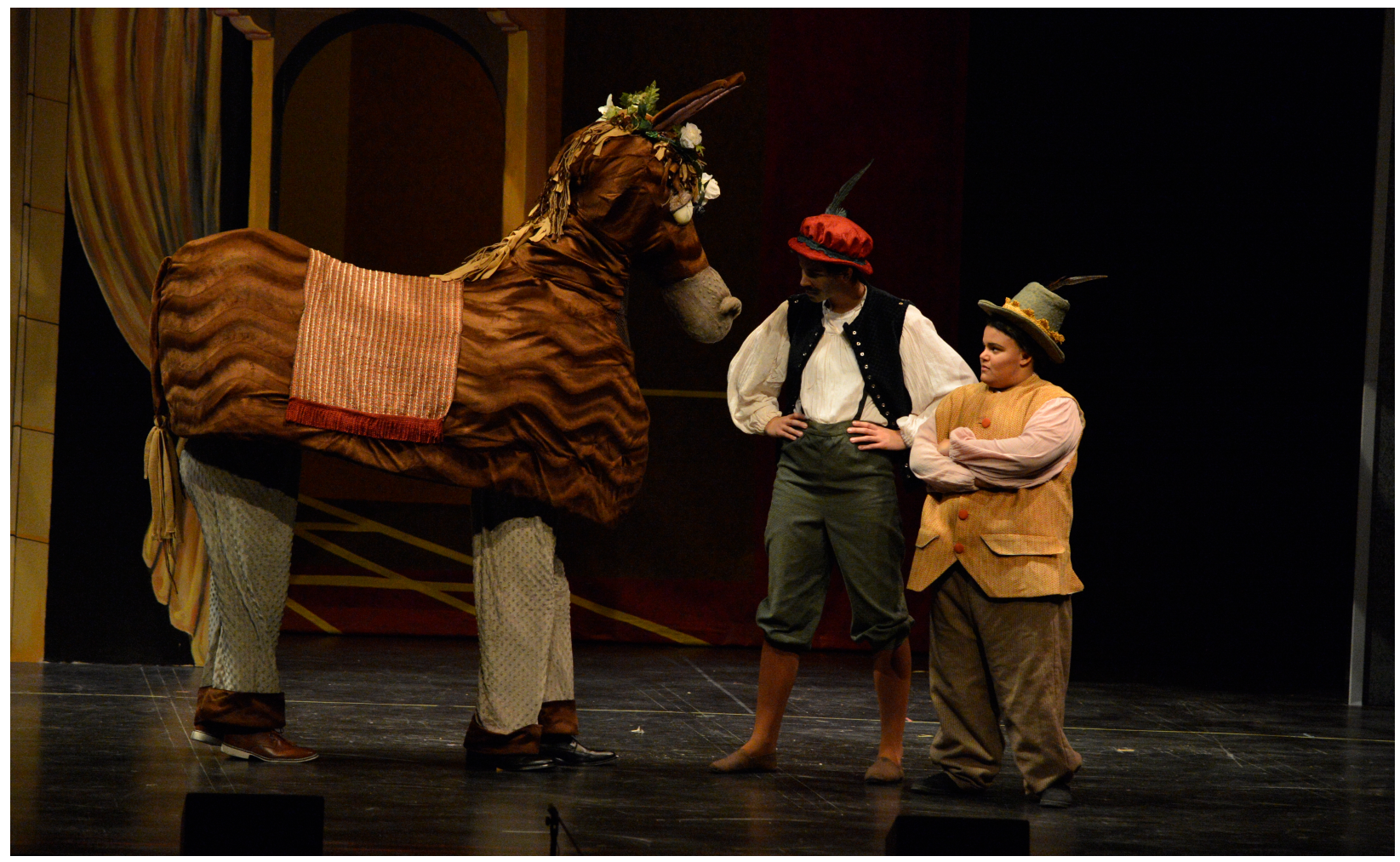

The Two Men size up the donkey.

West Virginia University Photography. The Two Men and the Donkey. 2015. Photograph. West Virginia University of Theatre and Dance, Morgantown, WV. Digital Image

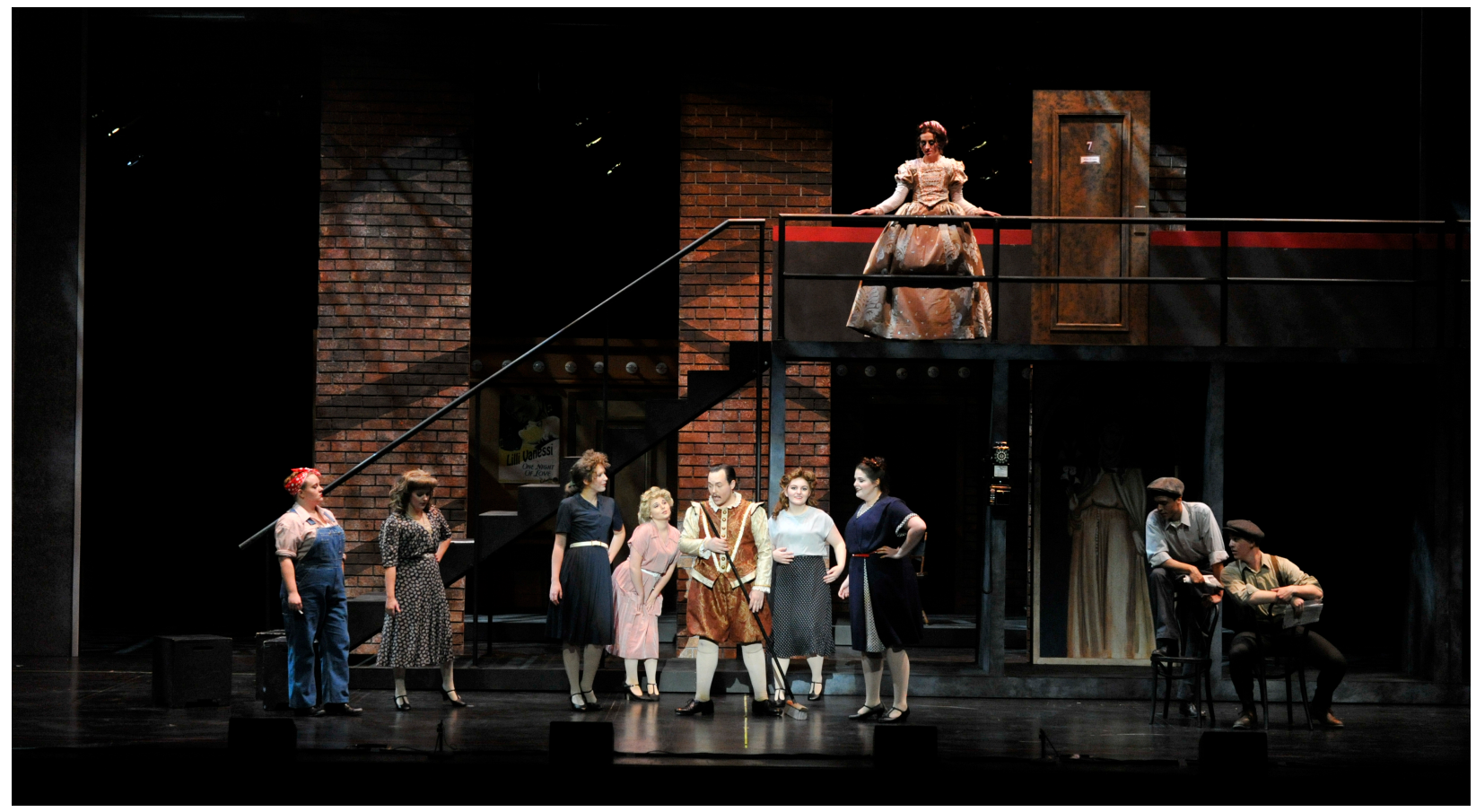

Bill sings backstage with some of the ensemble women while Lois (dressed as Bianca) watches.

West Virginia University Photography. Bianca. 2015. Photograph. West Virginia University of Theatre and Dance, Morgantown, WV. Digital Image. 


\section{Bibliography}

Britton, Bryce. Production Meeting with Design Team. March. 2015.

Pollard, Simon. "Kiss Me Kate, Teaching Resources." Old Vic New Voices

Education (2012) Http://oldvictheatre-assets.s3.amazonaws.com/assets/File/1556.pdf. Web.

Spewack, Sam, and Bella Spewack. Kiss Me, Kate. New York: Tams-Witmark Music Library, 2000. Print.

\section{List of Figures}

1. West Virginia University Photography. Another Op'nin, Another Show. 2015. Photograph. West Virginia University of Theatre and Dance, Morgantown, WV. Digital Image.

2. West Virginia University Photography. Backstage Dressing Rooms. 2015. Photograph. West Virginia University of Theatre and Dance, Morgantown, WV. Digital Image.

3.West Virginia University Photography. We Open In Venice. 2015. Photograph. West Virginia University of Theatre and Dance, Morgantown, WV. Digital Image.

4. West Virginia University Photography. Tom, Dick, or Harry. 2015. Photograph. West Virginia University of Theatre and Dance, Morgantown, WV. Digital Image.

5. West Virginia University Photography. Cantiamo D’Amore. 2015. Photograph. West Virginia University of Theatre and Dance, Morgantown, WV. Digital Image.

6. West Virginia University Photography. General Howell Arrives. 2015. Photograph. West Virginia University of Theatre and Dance, Morgantown, WV. Digital Image.

7. West Virginia University Photography. Brush Up Your Shakespeare. 2015. Photograph. West Virginia University of Theatre and Dance, Morgantown, WV. Digital Image.

8. West Virginia University Photography. Kiss Me Kate Reprise. 2015. Photograph. West Virginia University of Theatre and Dance, Morgantown, WV. Digital Image.

9. West Virginia University Photography. Bianca. 2015. Photograph. West Virginia University of Theatre and Dance, Morgantown, WV. Digital Image.

10. Beuckelaer, Joachim. Country Market. 1566. Museo di Capodimonte. Web.

11. Gross, Lori Ettlinger. "The Bling Factor | 'American Woman' at the Met." T Magazine The Bling Factor American Woman at the Met Comments. The New York Times Style Magazine, 11 May 2010. Web. 
12. Hill, Cecelia. Lilli Vanessi Rendering. 2015. Rendering. West Virginia University of Theatre and

Dance, Mogantown, WV. Digital Image.

13. West Virginia University Photography. Another Op'nin Another Show, Detail. 2015. Photograph.

West Virginia University of Theatre and Dance, Morgantown, WV. Digital Image.

14. Allori, Allessandro. Isabella De' Medici. 1560. Private Collection. Web.

15. Hill, Cecelia. Katherine Rendering. 2015. Rendering. West Virginia University of Theatre and Dance, Mogantown, WV. Digital Image.

16. Hill, Cecelia. Katherine Singing “Kiss Me Kate.” Photograph. West Virginia University of Theatre and Dance, Morgantown, WV. Digital Image

17."1940s Mens Fashion Uk." Mens Fashion Styles 1940s Mens Fashion Uk Comments. N.p., 27 Mar. 2015.

18. Hill, Cecelia. Fred Graham Rendering. 2015. Rendering. West Virginia University of Theatre and Dance, Mogantown, WV. Digital Image.

19. West Virginia University Photography. Fred Addresses the Cast, Detail. 2015. Photograph. West

Virginia University of Theatre and Dance, Morgantown, WV. Digital Image.

20. van der Meulen, Steven. Lord Robert Dudley. 1560. Private Collection. Web.

21. Hill, Cecelia. Petruchio Rendering. 2015. Rendering. West Virginia University of Theatre and Dance, Mogantown, WV. Digital Image.

22. West Virginia University Photography. We Open in Venice, Detail. 2015. Photograph. West Virginia

University of Theatre and Dance, Morgantown, WV. Digital Image.

23. West Virginia University Photography. Kiss Me Kate, Detail. 2015. Photograph. West Virginia

University of Theatre and Dance, Morgantown, WV. Digital Image.

24. “1940s Costume History - 1948 Pattern Cutting Fashion Pictures C20th Fashion History 1940s."

1940s Costume History. Fashon Era.

25. Hill, Cecelia. Lois Lane Rendering. 2015. Rendering. West Virginia University of Theatre and Dance, Mogantown, WV. Digital Image.

26. West Virginia University Photography. Fred Addresses the Cast, Detail. 2015. Photograph. West

Virginia University of Theatre and Dance, Morgantown, WV. Digital Image.

27. Titian. Portrait of a Lady in White. 1555. Wiki Art: Visual Art Encyclopedia. Web.

28. Hill, Cecelia. Bianca Rendering. 2015. Rendering. West Virginia University of Theatre and Dance, Mogantown, WV. Digital Image.

29. West Virginia University Photography. Cast Photo, Detail. 2015. Photograph. West Virginia University of Theatre and Dance, Morgantown, WV. Digital Image. 
30. Riding, Daniel. "A Decade In Fashion: The 1940's | Mens Fashion Magazine." Mens Fashion Magazine. Men's Fashion Magazine LTD, 21 May 2013. Web.

31. Hill, Cecelia. Bill Calhoun Rendering. 2015. Rendering. West Virginia University of Theatre and Dance, Mogantown, WV. Digital Image.

32.West Virginia University Photography. Another Op'nin Another Show, Detail. 2015. Photograph. West Virginia University of Theatre and Dance, Morgantown, WV. Digital Image.

33. van Herwijck, Steven. Robert Dudley Earl of Leicester. 1560. Wiki Art: Visual Art Encyclopedia. Web

34. Hill, Cecelia. Lucentio Rendering. 2015. Rendering. West Virginia University of Theatre and Dance, Mogantown, WV. Digital Image.

35. West Virginia University Photography. We Open In Venice, Detail. 2015. Photograph. West Virginia University of Theatre and Dance, Morgantown, WV. Digital Image.

36. Hill, Cecelia. First Man Rendering. 2015. Rendering. West Virginia University of Theatre and Dance, Mogantown, WV. Digital Image.

37. Hill, Cecelia. Second Man Rendering. 2015. Rendering. West Virginia University of Theatre and Dance, Mogantown, WV. Digital Image.

38. West Virginia University Photography. Brush Up Your Shakespeare. 2015. Photograph. West Virginia University of Theatre and Dance, Morgantown, WV. Digital Image.

39. Clouet, Francois. Charles IX as an adult. 1565. Wiki Art: Visual Art Encyclopedia. Web.

40. Hill, Cecelia. Hortensio Rendering. 2015. Rendering. West Virginia University of Theatre and Dance, Mogantown, WV. Digital Image.

41. Steven Neuenschwander . Cantiamo D'Amore, Detail. 2015. Photograph. West Virginia University of Theatre and Dance, Morgantown, WV. Digital Image.

42. English School. Portrait of James VI of Scotland, I of England and Ireland. 1619. Painting. Wiki Art: Visual Art Encyclopedia. Web.

43. Hill, Cecelia. Gremio Rendering. 2015. Rendering. West Virginia University of Theatre and Dance, Mogantown, WV. Digital Image.

44. West Virginia University Photography. Bianca, Detail. 2015. Photograph. West Virginia University of Theatre and Dance, Morgantown, WV. Digital Image.

45. Mielich, Hans. Portrait of Ladislaus von Fraunberg, Count of Haag. 1557. Painting. Liechtenstein: The Princely Collection. Web.

46. Hill, Cecelia. Baptista Rendering. 2015. Rendering. West Virginia University of Theatre and Dance, Mogantown, WV. Digital Image. 
47. Steven Neuenschwander. Baptista's House, Detail. 2015. Photograph. West Virginia University of

Theatre and Dance, Morgantown, WV. Digital Image

48. U.S. Army Airforce. General Anton, General Eisenhower, General Spaatz, General Doolittle, Major

General Kepner, and Colonel Blakeslee taken on the occasion of the awarding of the DFC Colonel Blakeslee and Captain Gentile. 1944. National Archives. Web.

49. Hill, Cecelia. General Harrison Howell Rendering. 2015. Rendering. West Virginia University of Theatre and Dance, Mogantown, WV. Digital Image.

50. Cecelia Hill. General Howell Remembers Lois, Detail. 2015. Photograph. West Virginia University of

Theatre and Dance, Morgantown, WV. Digital Image

51. Rockwell, Norman. Rosie. Saturday Evening Post, May 29, 1943, cover (AP2.S2). The Library of

Congress General Collections. Web.

52. Hill, Cecelia. Ma Rendering. 2015. Rendering. West Virginia University of Theatre and Dance, Mogantown, WV. Digital Image.

53. West Virginia University Photography. Ma. 2015. Photograph. West Virginia University of Theatre and Dance, Morgantown, WV. Digital Image.

54. Flicke, Gerlach. Portrait of Thomas Cranmer. 1545. Painting. Painting. National Portrait Gallery, Web.

55. Hill, Cecelia. Padua Priest Rendering. 2015. Rendering. West Virginia University of Theatre and Dance, Mogantown, WV. Digital Image.

56. West Virginia University Photography. Cantiamo d'Amore, Detail. 2015. Photograph. West Virginia

University of Theatre and Dance, Morgantown, WV. Digital Image.

57. Penney, J.C. Separates in Sail-Aweigh. N.d. Digital Image. Inspiration: Fashion Vintage Ads. Web.

58. Hill, Cecelia. Paulette Sketch. 2015. Drawing. West Virginia University of Theatre and Dance,

Mogantown, WV. Digital Image.

59. West Virginia University Photography. Too Darn Hot, Detail. 2015. Photograph. West Virginia

University of Theatre and Dance, Morgantown, WV. Digital Image.

60. Hollywood Patterns. Priscilla Lane Waistcoat, Skirt Pattern. N.d. Pattern Image. Heavens to Betsy

Vintage. Web.

61. Hill, Cecelia. Ralphie Sketch. 2015. Drawing. West Virginia University of Theatre and Dance,

Mogantown, WV. Digital Image.

62. West Virginia University Photography. Fred Addresses the Cast, Detail. 2015. Photograph. West

Virginia University of Theatre and Dance, Morgantown, WV. Digital Image.

63. Grant, Allan. LIFE Magazine. N.d. Photograph. LIFE Archives. Web. 
64. Hill, Cecelia. Dance Captain Sketch. 2015. Drawing. West Virginia University of Theatre and Dance, Mogantown, WV. Digital Image.

65.West Virginia University Photography. Too Darn Hot, Detail. 2015. Photograph. West Virginia University of Theatre and Dance, Morgantown, WV. Digital Image.

66. Hill, Cecelia. 1940s Ensemble Women Rendering. 2015. Rendering. West Virginia University of Theatre and Dance, Mogantown, WV. Digital Image.

67. Hill, Cecelia. 1940s Ensemble Dancers Rendering. 2015. Rendering. West Virginia University of Theatre and Dance, Mogantown, WV. Digital Image.

68. Hill, Cecelia. Stage Hands Rendering. 2015. Rendering. West Virginia University of Theatre and Dance, Mogantown, WV. Digital Image.

69. Hill, Cecelia. 1940s Ensemble Men Rendering. 2015. Rendering. West Virginia University of Theatre and Dance, Mogantown, WV. Digital Image.

70. West Virginia University Photography. Bianca, Detail. 2015. Photograph. West Virginia University of Theatre and Dance, Morgantown, WV. Digital Image.

71. West Virginia University Photography. Bianca, Detail. 2015. Photograph. West Virginia University of Theatre and Dance, Morgantown, WV. Digital Image.

72. Hill, Cecelia. Three Women of Padua Rendering. 2015. Rendering. West Virginia University of Theatre and Dance, Mogantown, WV. Digital Image.

73. Hill, Cecelia. Four Women of Padua Rendering. 2015. Rendering. West Virginia University of Theatre and Dance, Mogantown, WV. Digital Image.

74. Hill, Cecelia. Man and Woman of Padua Rendering. 2015. Rendering. West Virginia University of Theatre and Dance, Mogantown, WV. Digital Image.

75. Hill, Cecelia. Men of Padua Rendering. 2015. Rendering. West Virginia University of Theatre and Dance, Mogantown, WV. Digital Image.

76. West Virginia University Photography. Cantiamo d'Amore, Detail. 2015. Photograph. West Virginia University of Theatre and Dance, Morgantown, WV. Digital Image.

77. West Virginia University Photography. Cantiamo d'Amore, Detail. 2015. Photograph. West Virginia University of Theatre and Dance, Morgantown, WV. Digital Image. 